\title{
Efficacy of orally administered ritodrine after initial intravenous therapy
}

Citation for published version (APA):

Smit, D. A. (1983). Efficacy of orally administered ritodrine after initial intravenous therapy. [Doctoral Thesis, Maastricht University]. Rijksuniversiteit Limburg. https://doi.org/10.26481/dis.19830908ds

Document status and date:

Published: 01/01/1983

DOI:

$10.26481 /$ dis. $19830908 d s$

Document Version:

Publisher's PDF, also known as Version of record

\section{Please check the document version of this publication:}

- A submitted manuscript is the version of the article upon submission and before peer-review. There can be important differences between the submitted version and the official published version of record. People interested in the research are advised to contact the author for the final version of the publication, or visit the DOI to the publisher's website.

- The final author version and the galley proof are versions of the publication after peer review.

- The final published version features the final layout of the paper including the volume, issue and page numbers.

Link to publication

\footnotetext{
General rights rights.

- You may freely distribute the URL identifying the publication in the public portal. please follow below link for the End User Agreement:

www.umlib.nl/taverne-license

Take down policy

If you believe that this document breaches copyright please contact us at:

repository@maastrichtuniversity.nl

providing details and we will investigate your claim.
}

Copyright and moral rights for the publications made accessible in the public portal are retained by the authors and/or other copyright owners and it is a condition of accessing publications that users recognise and abide by the legal requirements associated with these

- Users may download and print one copy of any publication from the public portal for the purpose of private study or research.

- You may not further distribute the material or use it for any profit-making activity or commercial gain

If the publication is distributed under the terms of Article $25 \mathrm{fa}$ of the Dutch Copyright Act, indicated by the "Taverne" license above, 


\section{Efficacy of orally administered ritodrine after initial intravenous therapy}

Proefschrift

ter verkrijging van de graad van doctor in de geneeskunde aan de Rijksuniversiteit Limburg te Maastricht, op gezag van de Rector Magnificus Prof. Dr. H.C. Hemker, volgens besluit van het College van Dekanen in het openbaar te verdedigen in de aula wan de universiteit op donderdag 8 september 1983 , des namiddags te vier uur

door

Diederik Anton Smit

geboren te Ambon (Ind.) 
Referenten: Prof. Dr. M.J.N.C. Keirse, Rijksuniversiteit Leiden, Leiden Prof. Dr. H.A.J. Struyker Boudier, Rijksuniversiteit Limburg. Maastricht writen permission from the publisher.

Niets vit dene vigave mag worden vervel woudigden of openbar gemaak door middel vandruk. folocopie.

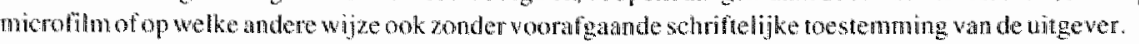


Ter nagedachtenis aan mijn vader.

Aan Emilie, Onno, Tessa en Maartje. 



\section{Contents}

\section{Chapter I}

\section{General introduction}

\section{Chapter II}

Preterm labour of unknown aetiology

2.1. Introduction

- Definition

- Incidence.

2.2. Physiological aspects of the pregnant uterus 5

- General remarks

- Anatomy of the myometrium 6

- Subcellular organization of myometrial muscle cells $\quad 6$

- Intercellular organization 9

- Relation between intra- and intercellular events 9

2.3. Hormone profiles during late pregnancy and the onset of labour 10

- Hormonal changes during pregnancy 10

- Female sex steroids $\quad 12$

- Oestrogens. 12

- Progesterone 14

- Progesterone/Oestrogen ratio (PE ratio) in plasma 15

- PE ratio in the myometrium 16

$\begin{array}{ll}\text { - Corticosteroids } & 17\end{array}$

- Oxytocin 18

- Prostaglandins 19

- Catecholamines 20 
Pharmacological aspects of beta ${ }_{2}$-sympathomimetic agents in obstetrics

3.1. Introduction 23

3.2. Drug dosage-effect pathway 24

- Pharmaceutical phase 25

- Pharmacokinetic phase 26

- Absorption 26

- Distribution 26

- Metabolism and excretion 27

- Serum levels 27

- Pharmacodynamic phase 30

3.3. Structure-activity-relationship 31

3.4. Mechanism of action on uterine tissue $\quad 32$

3.5. Biological effect on the pregnant uterus $\quad 33$

\section{Chapter IV}

The predictive value of uterine contractility and the serum levels of progesterone and oestrogens with regard to preterm labour $\quad 35$

4.1. Introduction 35

4.2. Patients and methods $\quad 37$

4.3. Results 38

- Relation between subjectively experienced uterine contractions and objectivated uterine contractions 38

- Relation between uterine contractility versus progesterone, oestradiol, $\mathrm{PE}_{2}$ ratio and $\mathrm{E}_{3} \mathrm{E}_{2}$ ratio

- Comparison of the measured parameters of the pathological pregnancies and those of the uncomplicated pregnancies

4.4. Discussion 


\section{Chapter V}

\section{Efficacy of orally administered ritodrine after initial}

intravenous therapy

5.L. Introduction

5.2. Materials and methods 48

5.3. Results 51

- Comparability between the ritodrine and the placebo group at the onset of intravenous treatment

- Comparability between the ritodrine and the placebo group during the intravenous treatment and the onset of oral treatment

- Judgment of success

- Comparison of the duration of oral treatment between the two groups

- Comparison of the duration of amenorrhoea at delivery between the two groups

- Comparison of the prolongation index between the two groups

- Comparison of the relative gain between the two groups

- Comparison of the neonatal outcome between the two groups

\section{Chapter VI}

Serum levels of ritodrine in clinical practice

6.1. Introduction

6.2. Serum levels during the initial period of intravenous ritodrine treatment

(first treatment period)

- Patients and methods

- Results

6.3. Ritodrine serum levels during reduction of intravenous therapy and switching to oral treatment (second treatment period)

- Patients and methods

- Results

6.4. Serum levels during oral maintenance therapy (third treatment period) 76

- Patients and methods

- Results

6.5. Discussion 
SAMENVATTING

REFERENCES

LIST OF ABBREVIATIONS

SLOTWOORD

CURRICULUM VITAE 


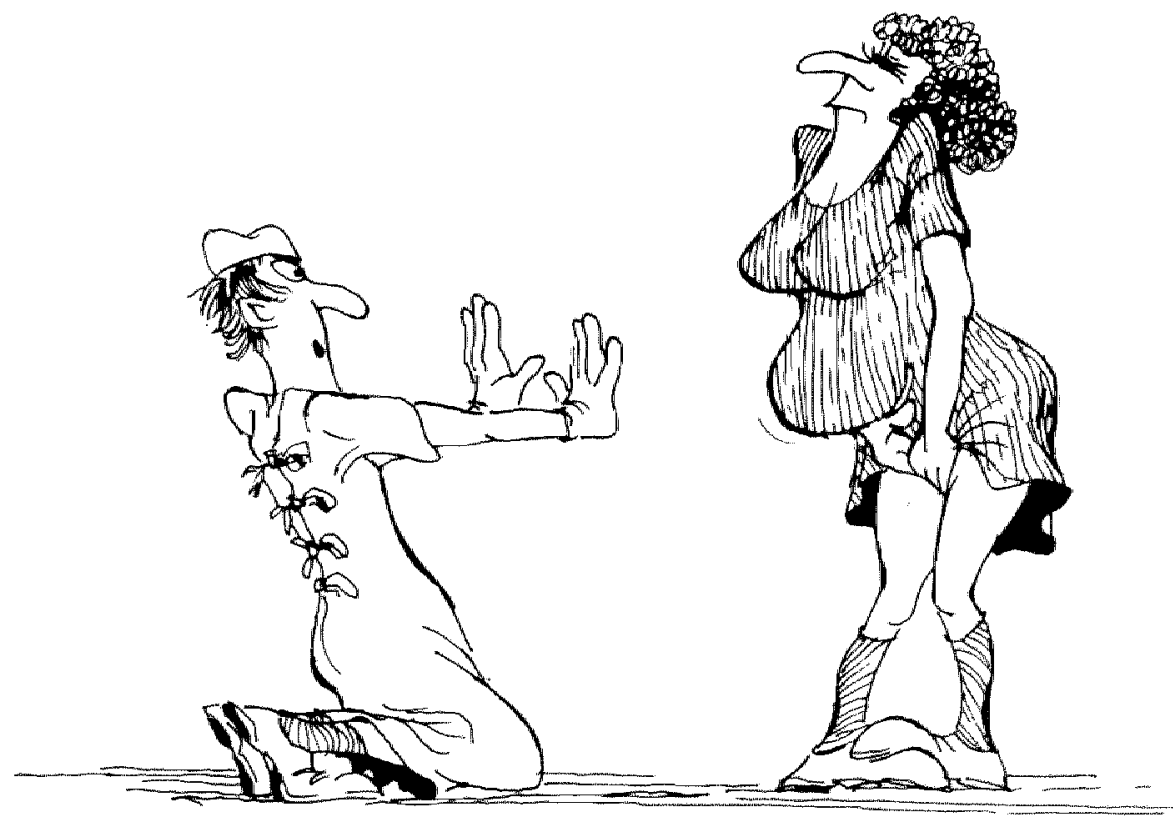

Fig. 1-l. 



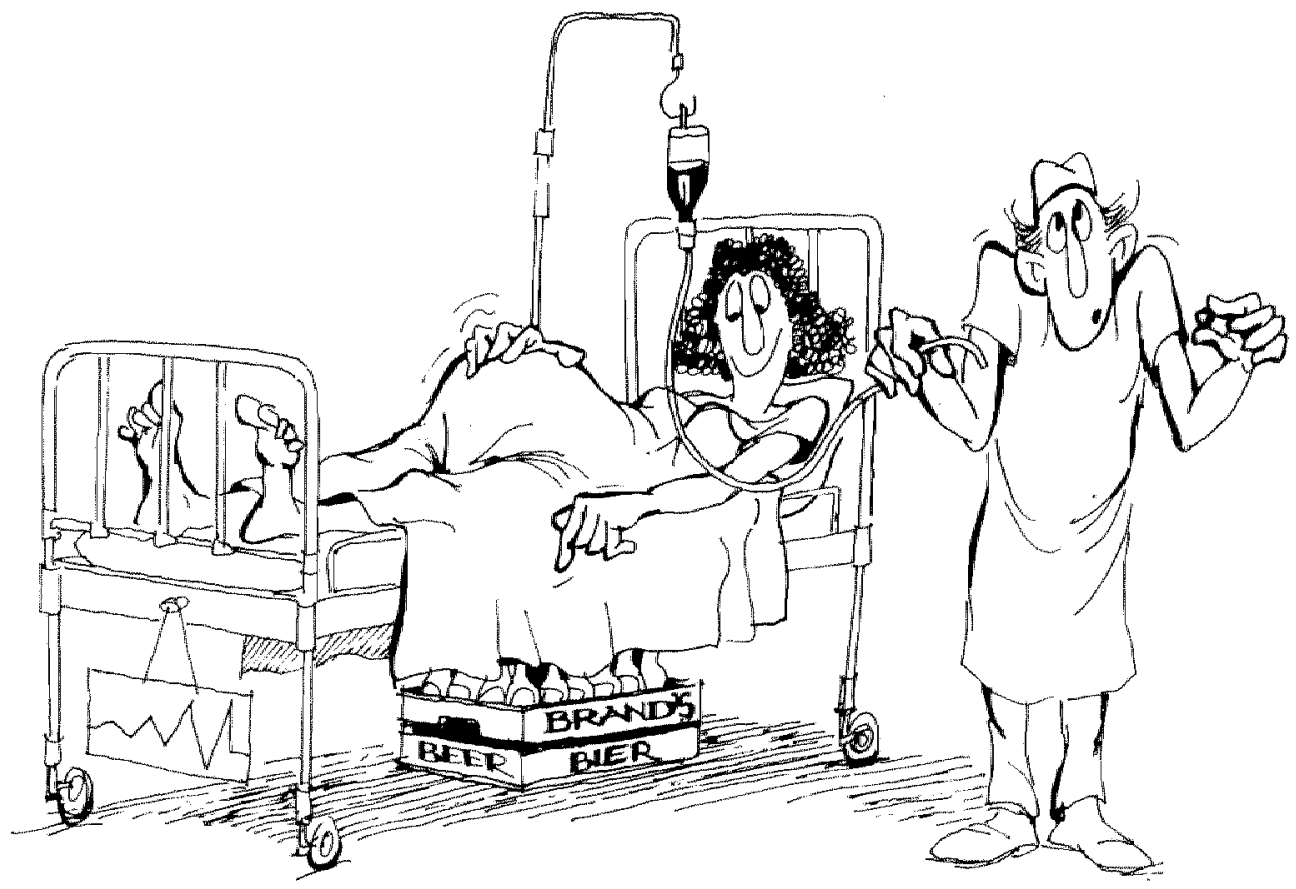

Fig. 1-2 


\section{CHAPTER II}

\section{Preterm labour of unknown aetiology}

\subsection{Introduction}

\section{Definition}

Defining preterm labour is mainly important for statistical reasons. In clinical use it is important to distinguish between threatening preterm labour and false labour, and as long as the mechanism of labour is not yet fully understood and thus no biophysical, biochemical or hormonal parameters, differentiating between true and false preterm labour are available, it will be an arbitrary clinical diagnosis. So early differentiation between true labour and false labour is often difficult before the uterus has contracted sufficiently to produce demonstrable effacement and dilatation of the uterine cervix. By that time, unfortunately, attempts to arrest labour may prove to be less effective.

Inherent to the practice of obstetrics is the division of gestation in periods in which untimely expulsion of the gestational products occur. Exact data concerning mortality and morbidity related to preterm deliveries are difficult to obtain and to compare, especially because of poor definitions, differences among populations and major differences in manpower, skill and equipment between perinatal care centres. In the past, warious definitions regarding gestational age at delivery have been used in the Anglo-American literature and not infrequently these differed from the definitions used on the European continent.

This surely complicated the comparison of neonatal outcome and results of efforts to prevent imminent preterm labour.

The definition of a shortened gestation has amply been discussed by expert committees of the World Health Organisation (WHO report, 1977). There is general agreement that the term 'premature' should no longer be used and that birth weight and gestational age should be considered separately.

The current WHO recommendation is that infants delivered within Iess than 37 completed weeks (less than 259 completed days) from the first day of the last menstrual period should be defined as 'preterm', while infants weighing less than $2500 \mathrm{grams}$ ate classified as being of "low birthweight". Those infants may be small for gestational age (S.G.A.) as well as appropriate for gestational age (A.G.A.). So "preterm" only applies to gestational age (being under 37 weeks) regardless of actual birthweight.

\section{Incidence}

Over the last few years mortality rates of preterm infants have gradually fallen (Alberman, 1974; Stewart, 1981). Data concerning morbidity are more difficult to obtain. However, there is still a small but important percentage (up to 10\%) of prematurely born infants left with a permanent major handicap (Davies, 1976; Stewart et all, 1977). Virtually all the studies show that, although the incidence of preterm delivery ranges from about 5 to over 9 per cent in Western Europe (Kloosterman, 1977; Rush et al., 1976; Kaltreider and Kohl, 1980; Kanhai, 1981), they account for the majority of early neonatal mortality. Fuchs 
(1976) reported that 8 per cent of deliveries which occurred before the 36 th week of pregnancy, accounted for about 75 per cent of perinatal deaths. Stillbirth and lethal deformities account for more than $10 \%$ of preterm deliveries and for more than $60 \%$ of the associated perinatal mortality (Rush et al., 1978).

There is a considerable lack of information about the epidemiological aspects of preterm labour. To obtain more insight in these aspects data of preterm deliveries should be classfied, as has been done by several authors (e.g. Bakketeig and Hoffman, 1981; Kanhai, 1981).

In general this classification inclucles 3 categories:

- preterm labour (or induced preterm labour) following intra-uterine foetal death. Preterm labour is a (desired) result of an intra-uterine catastrophe.

- induced preterm labour in cases in which maternal and/or foetal conditions disfavour prolongation of pregnancy. Foetal mortatity and morbidity are more related to the initial pathology than to prematurity as such.

- spontancous preterm labour with or without conditions known to have a prevalence to preterm labour. Mortality and morbidity are to some extent associated with the length of pregnancy and foetal condition at birth.

It would be easy to suggest that there are isolated causative factors inwolved in preterm delivery. It is much more likely that there are multiple interrelated factors both in terms of environmental and individual characteristics in addition to pregnancy complications. Wellknown conditions which have prevalence to preterm labour may be factors relating to the conceptus (toetus, amniotic fluid, foetal membranes, placenta), factors outside of the conceptus (health, age and constitution of the mother, uterine anomaly, socio-cconomic: factors etc.), or factors both inside and outside the conceptus. Several of these factors have been described in detail in the literature (Carpenter, 1982; Kaltreider and Kohl, 1980; Caritis et al., 1979) and are listed in table II-1.

Table 11-1: Factors implicated in preterm labour (after Caritis el al., 1979).

Maternal:

Foetoplacental:

Utherine:

Other:
Severe systemic diseases

Endocrine disorders

Trauma

Orgasm

Socioecononic status

History of preterm brith

Genital infection

Genetic abnormalities

Foetal death

Abruptio pllacentae

Placenta praevia

Overdistention

Malformation

Infection

Foreign body

Rupture of membranes

Cervical trauma

latrogenic 
Preterm labour of unknown aetiology is defined as preterm labour without a recognized aetiological moment: without a factor, generally spoken, attributant to preterm labour. Because of incomplete knowledge of the mechanisn of human parturition the abovementioned conditions are raised by some authors to aetiological moments. About half of all spontaneous preterm labour starts without one of the above-mentioned conditions (Caritis et al., 1979; Rush et al., 1976). This preterm labour of unknown aetiology is the most interesting and challenging group of preterm labour from the point of view of aetiology and management.

Up to now, no specific differences between the onset of preterm and term labour have been found. Much has been written about controlling uterine contractions. Data resulting from these studies have led to many hypotheses to explain the control of uterine contractions, and by reversing these theories to postulations regarding the onset of labour as well. Many of these theories are controversial, which is easy to understand, realizing that most of the above-mentioned work has been done in vitro and/or examined in animal experiments.

Thus far, despite all the research that has been undertaken within this ficld, there is not yet one single, generally accepted theory explaining the onset of parturition. On the other hand, as a sequel to all these studies, drugs have been developed with the qualities to influence the system, either to inhibit or to induce uterine contractility.

Because possible differences on cellular and subcellular levels between preterm and term labour have not yet been defined, the onset of preterm labour will be discussed with reference to recognized factors concerning the onset of term labour.

\subsection{Physiological aspects of the pregnant uterus}

\section{General remarks}

The uterus is an intriguing muscular organ. No other smooth muscle grows for a period of nine months, during which time its op timal function is obtained by being relaxed, and is then called upon to perform a considerable amount of contractile work during a period of hours.

The wet weight of the uterus increases $10-20$ fold during pregnancy. The fastest rate of weight increase occurs during the last third of this period.

This is due mainly to the hypertrophy of the smooth muscle cells of the myometrium. The uterus has the capacity to contract at any time during pregnancy and as pregnancy progresses it shows sporadic contractions with increasing frequency (Braxton Hicks contractions). If only a few of the myometrial cells contract any one time, other cells may be stretehed and the net-effect on the intra-uterine pressure is thereby minimal. Only when a majority of cells contract simultaneously, the int ra-uterine pressure will increase as a result of these contractions.

Although no particular cells or cell groups have been identified to which a pacemaker function may be ascribed, the cells in the cornua have the highest degree of excitability, so they are believed to act as pacemakers by some investigators (Alvarez and Caldeyro-Barcia, 1954). According to them, that is why during coordinated uterine activity the contractions usually begin in the fundal area, and the activation of the myometral cells then spreads rapidly over the uterus towards the cervix. At term, the transition from the state of 
pregnancy with sporadic contractions to the state of labour with frequent, thythmic contractions often eludes both the patient and the obstetrician, because it is so gradual that it is difficult to locate the end of one state and the beginning of the other.

One way to understand this change is perhaps the division of smooth muscle cells in either single-unit or multi-unit muscle cells. The uterus can be regarded as a single-unit organ during labour, but during pregnancy as multiple independent units (van Leeuwen et al., 1979).

The gradual Iransition from pregnancy to labour is in agreement with the assumption that the activity of the myometrium depends on the relationship between factors designed to keep the uterus at rest and factors which facilitate contractions. The balance is obviously delicate and as a result considerable variations occur in length of gestation. In the women the difference between 'normal' variations in the duration of pregnancy and those classified as pathological, such as preterm and postterm labour, are based on statistical time limits and not on differences in the physiological behaviour of the uterus.

The maintenance of uterine relaxation during pregnancy could be brought about either by making the myometrial cells less responsive to stimulation or by preventing contractile stimuli from reaching the myometrium. The first type of mechanism involves changes of the physico-chemical properties of the myometrial cells, blocking the conduction of impulses from one cell to another, preventing the interaction of the contractile proteins actin and myosin, interfering with the ion transport involved in the contraction-relaxation process, or inhibiting the metabolic transformations providing energy for the contractile process. The second type of mechanism could prevent stimuli from reaching the target organ, the uterus, by blocking nerve conduction in the central nervous system or efferent pathways. or by blocking nerve cells in the uterus itself, by preventing the release of humoral factors capable of stimulating the myometrial cells, by inactivating such agents before they reach the target cells, or by blocking the receptor sites for such agents in the target cells. There is a considerable amount of evidence in support of the view that the function of the myometrium during pregnancy and parturition is regulated by hormones. This does not exclude the possibility, however, that other factors (mechanical factors like stretch of the myomctrial cells or neurogenic factors) may play important roles ats well.

\section{Anatomy of the myometrium}

The human myometrium is composed of smooth muscle cells in a network of intricately interwoven bundles. A differentiation could be made between circular and longitudinal muscle cells, with distinguished physiological and pharmacological characteristics. The pattern is designed to provide continuous protection for the growing foetus as well as the optimal mechanical conditions for its expulsion. Most of the fibres follow a spiral course and some of them continue into the cervix. Most of the cervical tissue consists of dense fibrous tissue. Toward term, probably due to hormonal influence, this tissue softens considerably. When the muscle fibres extending into the cervix contract, in primigravidae they first 'toke up' the cervix (effacement) and then open the os, whereas in multigravidae these processes elapse mote or less simultaneously.

\section{Subcellular organization of myometrial muscle cells}

As in striated muscle cells, myometrium smooth muscle cells obtain myosin filaments and 
actin flaments. Besides these two protens there is a third type, an intermediate flament. forming a network, linking protein structures, known as dense bodies.

These intermediate filaments and dense bodies are analogous in function to the Zames of the striated muscles. They do not play an active role in the contractite process. They rather form a flexible structural nework, which links the actin and myosinfilaments into integrated mechanical units. This highly flexible organization enables the uterus to adapt to virtually any shape and to generate the forces necessary for labour with foetuses in various positions and sizes.

Myosin is composed of two parts (Huszar and Roberts, 1982): a 'tail', forming the 'backbone' of the myofilament and a 'head' (including two light chains), which is the location of three important functions:

- the actin-combining site, where myosin and actin combine to generate forces,

- the ATP-ase site, where ATP is broken down and chemical energy is converted into mechanical or pulling forces,

- the light chains, which, when phosphorylated, constitute the key element of contractile regulations.

Actin is a globular protein. The actin monomers polymerize into long thin filaments.

During uterine contractions the myosin heads and actin molecules form cross-bridges that generate the contractile force of labour.

In striated as well as in smooth muscle cells, calcium is stored in intracellular vesicles, the caveolae intracellulares (Daniel and Lodge, 1972), localized in the sarco-plasmic reticulum. The calcium shift from the inside of these vesicles (bound calcium) to the intra-cellular space (free calcium) is essential for contraction regulation. This process is influenced by several hormones, especially by catecholamines.

Adrenaline is thought to act as a first messenger, stimulating adenylcyclase, an enzyme, located on or within the cell membrane (fig. 2-1). Adenylcyclase accelerates the conversion of adenosine triphosphate (ATP) to cyclic adenosine monophosphate (cAMP): cAMP acts as a second messenger. One of the effects of the elevated cAMP formation is the accumulation of calcium by the sarcoplasmic reticulum calcium pump within the caveolac intracellulares, resulting in a decrease of the free intracellular calcium level (Sutherland and Rall, 1960; Rasmussen and Tenenhouse, 1968; Nishikori and Maeno, 1979: cited by Huszar, 1980).

CAMP activity is limited by conversion in the inactive metabolite 5 adenosine monophosphate. This hydrolysing reaction is catalyzed by phosphodiesterase (Berg ct al. $1982)$.

A second mechanism to lower the amount of free intracellular calcium is the extrusion of calcium from the inside of the cell to the extracellular space. There is a concentration gradient of calcium of 1:5000 (intracellular versus extracellular) in the resting state. This gradient is transiently increased a hundredfold during maximal activity. During repolarisation callcium is repulsed extracellularly; the energy for this mechanism is obtained by the ATP-ase system.

In smooth muscle cells, actin-myosin interaction is regulated through enzymatic phosphorylation or dephosphorylation of the myosin light chains. Actin-myosin interaction can take place only if myosin has been phosphorylated. Phosphorylation occurs through the action of myosin light chain kinase (M.L.C.K.), an enzyme that is activated by calcium. 


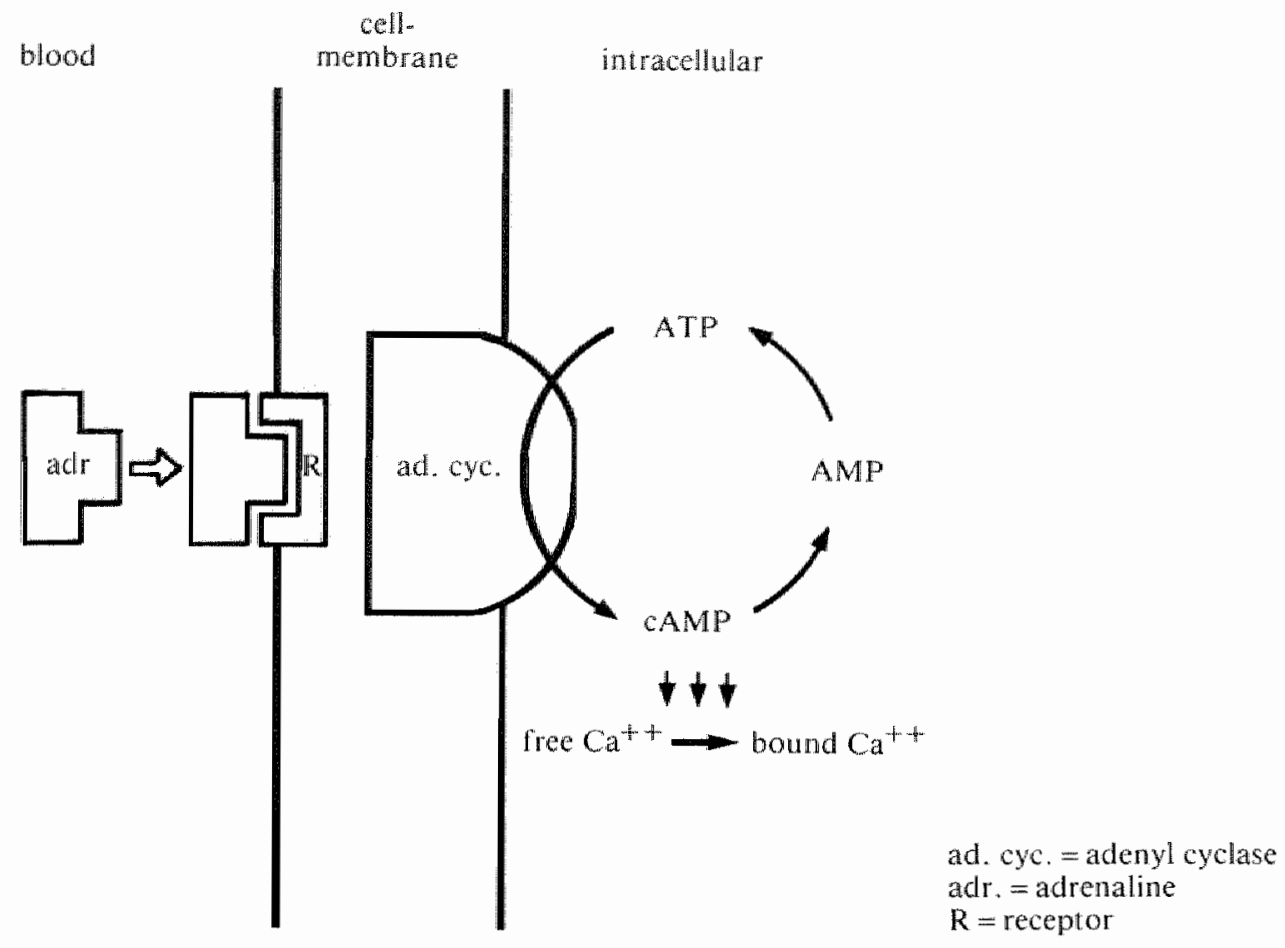

Fig. 2-1: Effect of carecholamines on myometrial muscle cells.

Relaxation of the smooth muscle occurs when another enzyme myosin light chain phosphatase removes the phosphate group from the myosin molecule. Actin does not 'recognize' the dephosphorylated myosin: hence no further actin-myosin interaction can take place. So the contractile state of smooth muscle cells depends on kinase activity as well as on phosphatase activity. The kinase activity is influenced by three intracellular regulatory systems. Firstly, the stimulating role of free calcium (Yagi et al., 1978): secondly, calmodulin, a calcium-dependent regulatory protein (Yagi et al., 1978; Grand and Perry, 1978) and finally, cAMP which has an inhibitory effect on the kinase activity (fig. 2-2).

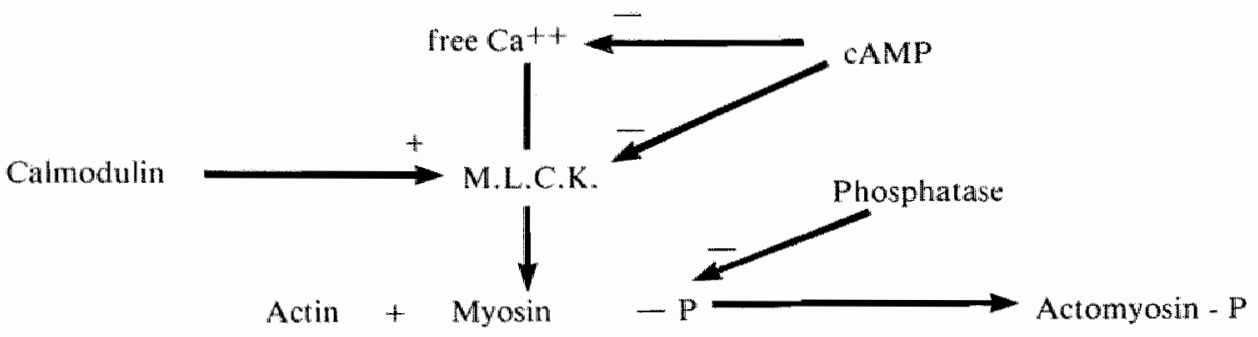

Figure: 2-2: Actin-myosin-phosphate regulating system. 
These mechanisms are under influence of the hormonal state and can be altered by exogenous changes of the system (fig. $2-4$ ). This scheme will serve in the following text as a matrix to explain the mode of action of hormones and drugs.

\section{Intercellular organization}

As already mentioned myometrial smooth muscle cells are embedded in extracellular material, composed manly of collagen fibres, which act as intracellular tendons. This connective tissue integrates the action of the muscle by transmitting the contractile force that is generated within the individual muscle cell.

The cells communicate with one another through connections called gap junctions. Garfield et al. (1978) believe these cell-to-cell contacts to be implemental in organizing the uterine contractions for labour. During pregnancy the presence of these gap junctions between uterine smooth muscle cells are exclusively limited to the period just prior to, during and immediately following parturition and has significant implications with reference to the maintenance and termination of pregnancy. The absence of gap junctions between smooth muscle cells throughout gestation until the beginning of labour may maintain pregnancy by limiting electrical communication between cells and so preventing coordinated contractions of the uterus.

The rapid formation and appearance of gap junctions may initiate or allow initiation of parturition and terminate pregnancy by providing large arcas of low resistance between the cells, allowing the spread of electrical information.

The spread of this current over the myometrium is supposed to synchronize uterine activity.

Gap junction formation is partly controlled by steroid hormones and prostaglandins. Garfield et al. (1980 a) showed an increasing number of gap junctions in myometrial tissue of pregnant rats in vitro. Statistically this was more relevant near term than in the immature period. Injection of immature animals with oestrogens increased the number of gap junctions. However, in the presence of oestrogens, progesterone decreased the number of gap junctions. Finally addition of indomethacin inhibited the formation of gap junctions but the addition of a stable analogue of the prostaglandin endoperoxide, prostaglandin $\mathrm{H}_{2}$ overcame the in hibition produced by indomethacin.

In 1980, Garfield et al. (1980b) showed that isoxsuprine decreased the number and size of the gap junctions in the myometrium of pregnant rats in vitro.

In 1981, Garfield and Hayashi published the results of electron microscopical examination of human myometrium, obtained during Caesarean section. Gap junctions were present between smooth muscle cells with low frequency in women with a closed cervix and infrequent contractions of the uterus. There was a statistically significant correlation between increased cervical dillation or increased frequency of uterine contractions and increased area of gap junctions.

A model for the control of parturition was designed by Garfield et al. (1978) (fig. 2.3).

\section{Relation between intra- and intercellullar events.}

A model for the understanding of smooth muscle ellectrical activity can be drawn by designating the cell wall as a conducting membrane which is selectively permeable to specific ions and which separates two different solutions of salt: the intracellular and 


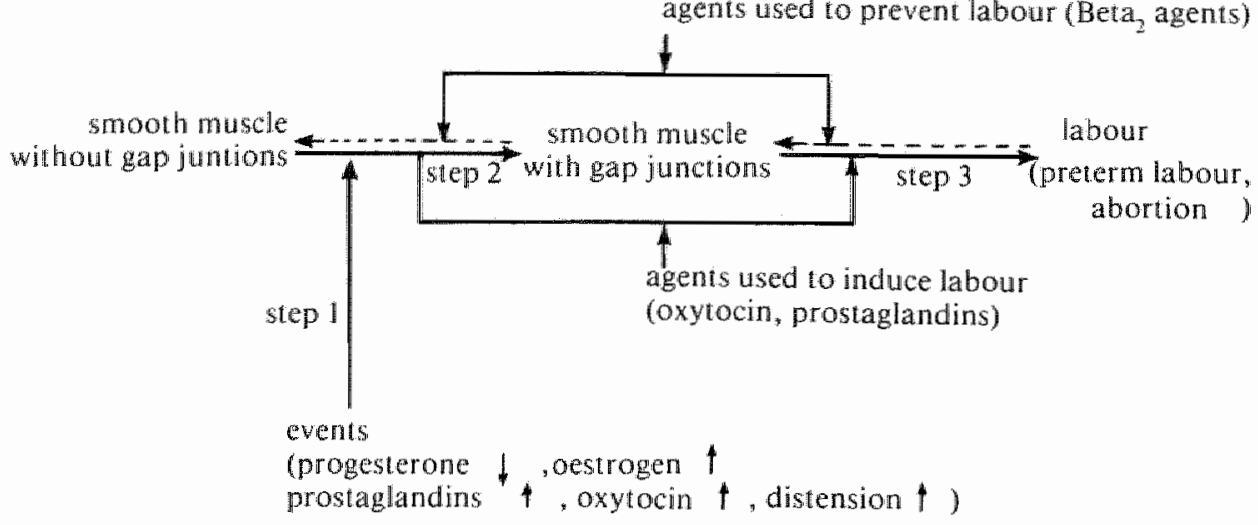

Fig. 2-3: Gap junctions and the control of parturition (Garfield et al., 1978).

extracellular fluid. Electrically charged ions, such as potassium, calcium, sodium and chloride form an aquilibrium, resulting in a resting potential.

The mombrane potential is unstable (possibly by intracellular metabolic processes) and shows generally irregular fluctuations of some millivolts up to some tens of millivolts. When these fluctuations cross a threshold, the membrane potential becomes an action potential, resulting in a contraction.

During the elevation of the resting potential (hyperpolarisation) there will be an influx of calcium into the cell (Osa, 1971: cited by van Geldrop, 1980).

An action potential or a "spike" leads to a single contraction of one myometrium cell: a burst of spikes results in a tetanic contraction of that specific myometrium cell. The quality of cellular interaction depends on the hormonal status: prerequisite for intercellular synchronisation is an electrical continuity between the cells, with a low electrical resistance.

These short circuits are believed to be the gap junctions. Finally an integrated model is presented, showing the regulation of smooth muscle contractility. Circled agents promote contractility; agents enclosed in grid promote relaxation (fig. 2-4)

\subsection{Hormone profiles during late pregnancy and the onset of labour}

\section{Hormonal changes during pregnancy}

The levels of almost at hormones rise with advancing gestational age and, although the rate of increase may change close to term, these changes are certainly neither dramatic nor consistent from one individual to another (Fuchs, 1977).

A main problem in the interpretation of endocrine changes at or before the onset of labour is the relative importance of and the temporal relationship between maternal and foetal contribution. Moreover, changes in the level of one hormone may induce changes in other hormone levels, and the inaccessibility of the human foetus renders it difficult to examine which one of these initiates the alteration. 


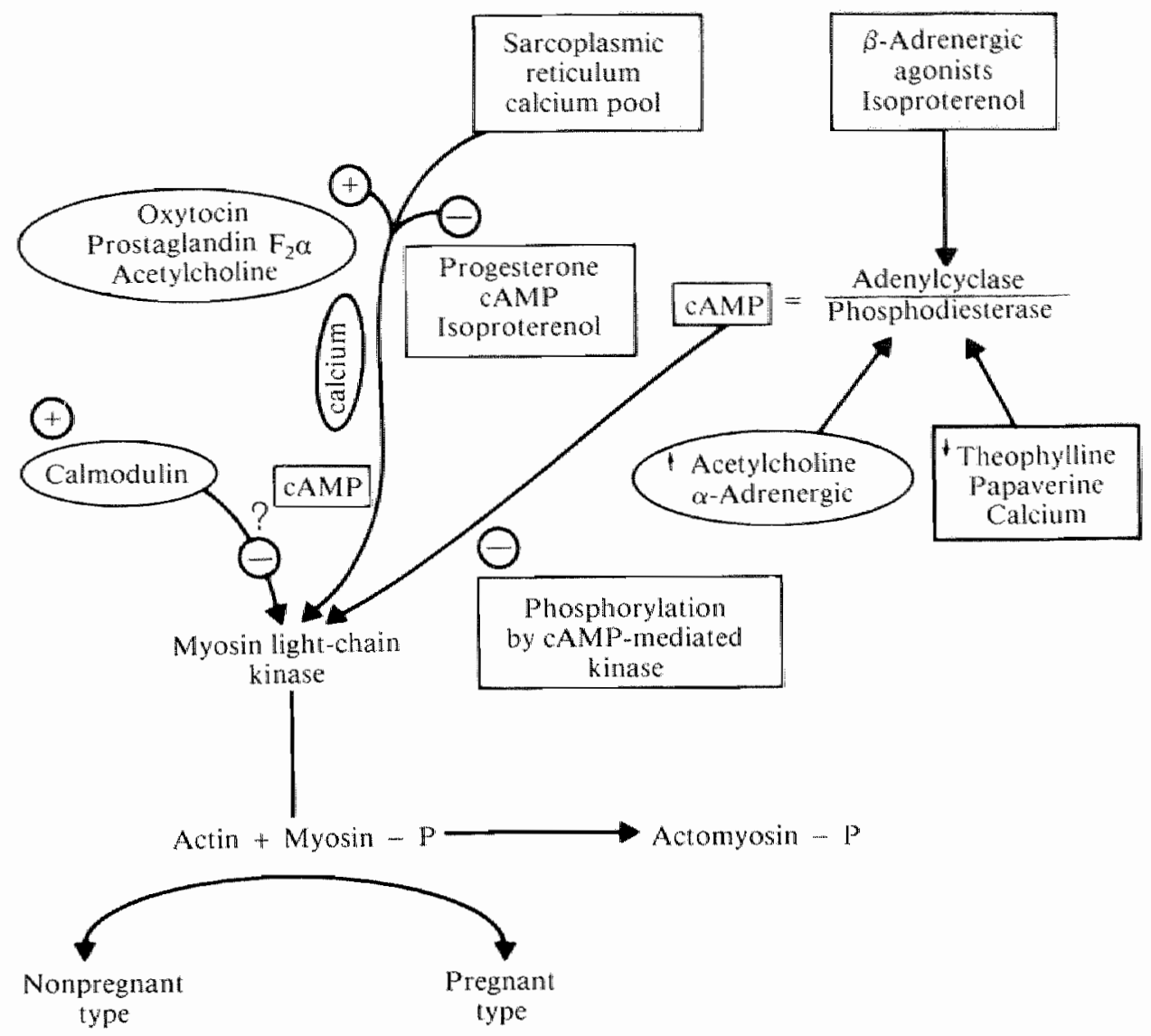

Fig. 2.4: Integrated model for regulation of smooth muscle connachlity (thszar, 1980).

One may wonder whether blood levels are relevant at all. As compared to urine levels, blood levels give more accurate information concerning hormonal events around the target cells, but what ultimately counts is the situation within the target cells. In this regard the ability to monitor changes is still extremely limited. Within the individual cell or groups of functionally simillar cells, the response depends on such factors as the amount of receptor protein available, the affinity of the receptor to the hormone in question, the transfer rate of the hormone-plus-receptor complex to the nucleus, the interpretation of the message by nuclear components, the transmission of the message to the extranuclear functional elements of the cell, etc. The mechanism of action of hormones has been studied mainly with protein synthesis as the final result (Batra, 1980) (fig. 2-6).

Formation of a hormone-receptor complex may directly influence $\mathrm{pH}$, permeability, excitability, movements of jons between subcellular organelles, etc.. The stuation is complicated by the fact that target cells may have a high affinity for several hormones which may compete for the available receptor sites, or one hormone may determine the binding capacity for another hormone without itself necessarily occupying the binding sites 
for this hormone. Myometrial cells appear to be target cells for at least the following hormones: oestrogens, progestagens, corticosteroids, oxytocin, prostaglandin and Catecholamines. It is also conceivable that other hormones in pregnancy have a modifying effect on the action and interaction of these hormones.

Although the blood levels of the warious hormones in pregnancy may have little functional relevance, it is nevertheless necessary, in the absence of better evidence, to consider the blood levels of the hormones at the onset of labour in an attempt to develop a model for the mechanism of human labour.

Recently, detailed reviews concerning hormonal changes during pregnancy and the onset of labour have been published (Fuchs, 1976; Batra, 1979; Thorburn and Challis, 1979). Also several textbooks (Fuchs and Klopper, 1977; Speroff et al., 1979) and special editions in scientific series (Josimowich, 1972; Keirse et al. 1979) give well-documented information of present knowledge about the onset of labour. Some of it is summarized in the next section.

\section{Femalle sex steroids.}

Oestrogens and progesterone are often discussed together because of their antagonising character and their mutual relationship: a change in the Progesterone/Oestrogen ratio (PE ratio) has been advocated as an important key to the recognition of the onset of parturition and as a valuable parameter for the prediction of preterm labour. Oestrogens and progesterone will first be discussed separately to explain their role in the control of uterine contractility.

\section{Oestrogens}

During pregnancy the main site of oestrogen production is the foeto-placental unit. The pathway of oestriol production is shown in the next diagram (fig. 2-5).

A less important pathwy for oestrogen production is the conversion of cholesterol into dehydroepiandrosterone-sulfate (DHEAS) in the maternal adrenals. Like (a small amount of) foetal DHEAS, this is converted in the placenta into oestradiol and oestrone (Sitteri and MacDonald, 1966).

During pregnancy oestrone and oestradiol excretion is increased about 100 times over non-pregnant levels. However, the increase in maternal oestriol excretion is about a thousandfold (this cnomous rise coupled with its dependency on foetal precursor is the busis of its utility in foetal monitoring). Ninety per cent of oestriol excretion can be accounted for by DHEAS production by the foetal adrenal glands. Although oestriol is quantitatively the most important oestrogen, ocstradiol seems to be the most potent one (Kelly, 1961; Pinto et al., 1967; Larsen et al., 1973; Cohen, 1976).

The effect of oestrogens upon the pregnant uterus is not yet fully understood. It is generally belicved that oestrogenic compounds increase the contractile response of the uterus (Csapo, 1956), but results of in vitro experiments suggest an inhibitory effect (Mossman and Conrad, 1967). On the other hand, the data of Standar and Barden (1970) show that preincubation with oestrogens sensitizes the myometrium to the action of other stimulants. These results can be explained by "receptors".

Hore the term receptor is used to describe an entity at cellular level that may receive a 
Mat.comp. :

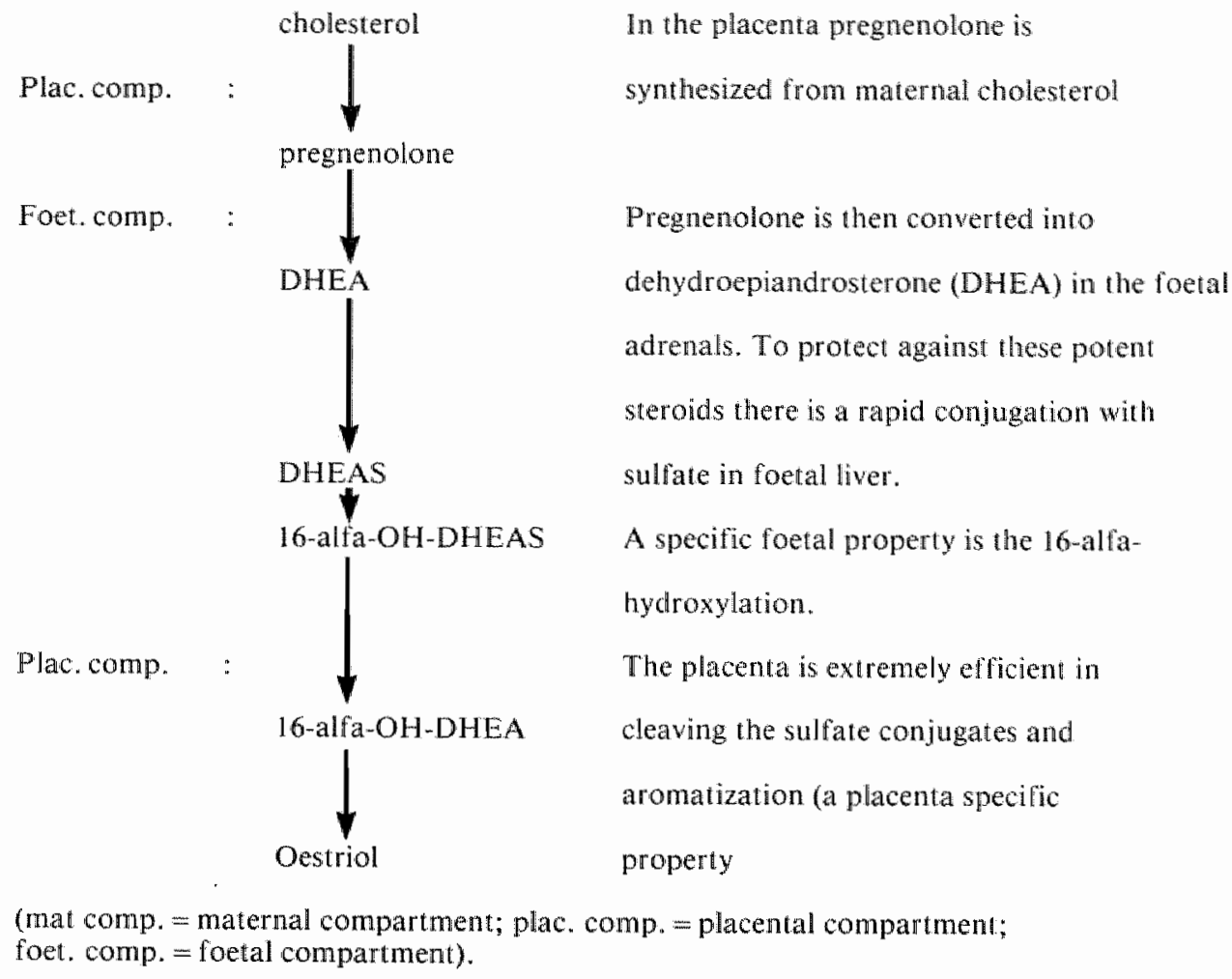

Figure 2-5: Oestrogen pathway.

stimulus. This stimulus may be an endogenous one $1, \mathrm{c} \cdot \mathrm{g}$. a hormone) or an exogenous one (e.g. a drug). The binding of a receptor and a stimulus will subsequently result in an effect. It is not clear whether a receptor is specific, or whether it may receive stimuli of different kinds: for example, it has been postulated that alpha- and beta-adrenergic receptors are structurally related and may in fact represent alternate configurations at the same active site (Roberts et al., 1977).

On the other hand, receptors provide tissue selectivity. In most cases a hormone regulates its own receptor concentration, but conwincing data are now availablc, indicating that oestrogens augment the synthesis of its own and progesterone receptors (Roberts, 1975) Oestrogens also increase the number of oxytocin receptors (Soloff et al., 1979). prostaglandin receptors (Naylor and Poyser, 1975) and alpha-adreno receptors (Roberts ef al. 1977), making the uterus more sensitive for these hormones.

Common to all stimulus-receptor reactions is the non-specificity of the link reaction that produces the physiological effect. This link process is the cnergy system inwolved in CAMP. According to Batra (1980) the mechanism of oestrogen stimulation upon the receptor may be understood, as presented in figure 2-6. 


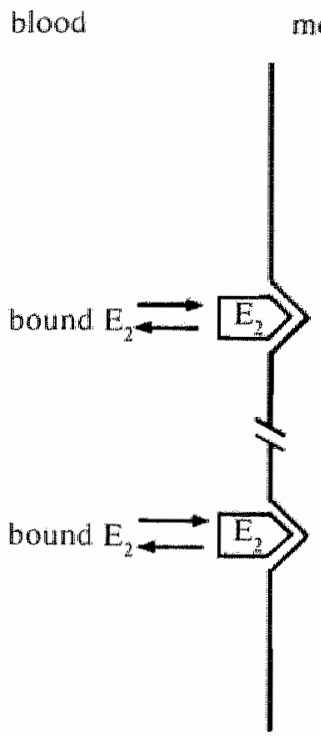

cell-

membrane intracellular

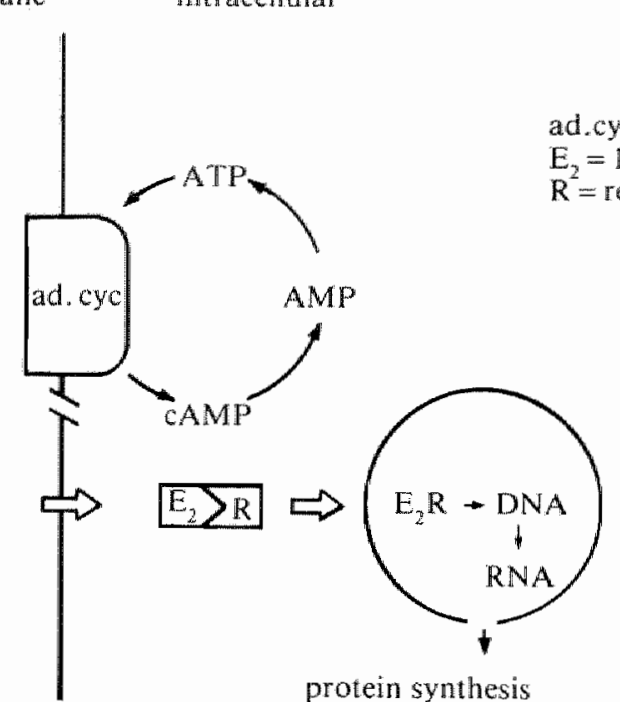

Fig. 2-6: Effect of oestradiol on myometrial muscle cells.

So oestrogens can effect myometrial contractility by the adenylcyclase-cAMP system. A second mechanism to influence the intracellular calcium level, and as a result the uterine contractility, is the trans-membrane calcium movement (Batra and Bengtsson, 1978a). Oestrogens also seem to be active in the induction of gap junctions. Neither the exact way of formation of gap junctions, nor their function, however, is completely understood (Garfield et al., 1978).

There is general agreement that oestrogens have a stimulating effect on uterine contractility. Alrady in 1931. Reynolds observed increased myometrial contractions after administration of ocstrogens to ovariectomized rats. Similar experiments were reported by Csapo et al. . 1973 who showed a fourfold increase in the rate of preterm delivery after administration of ocstradiol to ovariectomized rats.

\section{Progensterone}

In early pregnancy progesterone is largely formed by the corpus luteum during about the first 10 weeks of gestation. The production of progesterone by the placenta increases significantly since the 7 th week of gestational age and the placenta remains by far the most important site of progesterone production (Speroff et al ", 1978). Only a small amount of progesterone, even at term, is synthesized in the corpus $\|$ uteum: the significance of the latter production is unknown (Lemaire et al., 1970). Just like oestrogens, progesterone is synthesized by the placenta from maternal cholesterol via pregnenolone. Unliki oestrogens, as has been shown in fig. $2-5$, regarding the pathway of oestriol production, the foetus plays no role at all, when it comes to progesterone synthesis. So the only way the foetus might influence the oestrogen/progesterone ratio is by means of its participation in the synthesis of oestrogens. 
The role of progesterone for the foetus is not fully elucidated; it might serve as a substrate pool for the production of gluco- and mineralocortocoids (Speroff et at. , 1978).

Furthermore, Siiteri et al. (1976) called attention to the immuno-suppressive properties of progesterone, suppressing the maternal immunological response to the foetus.

Progesterone plays an important role in the relaxation of the uterus by lowering the intracellular calcium (Nishikori and Maeno, 1979). Progesterone was demonstrated to have an ATP-dependent calcium lowering effect, promoting the uptake of calcium by the Sarcoplasmic reticulum (Carsten, 1979). Possibly this ATP-dependent effect is regulated by decreasing the alpha-adrenergic receptors on the myometrium cell (Roberts et al. 1977). Garfield et al. (1978) emphasized the role of progesterone in the control of gap junction formation. As has been shown in fig. 2-3, progesterone has a negative effect on step 2, thus preventing quick intercellular transmission of the electrical pulses, necessary to produce coordinated uterine contractions.

\section{Progesteronel Oestrogen ratio (PE ratio) in plasma}

Oestrogens as well as progesterone have a strong influence on the human myometrium as has been discussed previously. The fascinating finding that the main placental hormones the production of which increases tremendously in the course of pregnancy - induce completely opposing effects with regard to uterine contractility, has led to research concerning a possible relationship between the progesterone/oestrogen ratio (PE ratio) and the onset of labour. It is quite understandable, however, that this research discharges itself into a "continuing controversy" (Flint, 1979) if one bears in mind the following considerations:

- There can be a large inter-individual spread and individual variation between two consecutive weeks (Lindberg et al., 1974; Compton et al., 1979).

- Diurnal variations up to $15 \%$ have been determined by Katagiri et al. (1975), although Masson and Wilson (1972) found negligible differences.

- PE ratio has been shown to decrease after induced labour (Kauppila et al., 1980), but this decrease may be a result instead of the cause of the onset of Jabour.

Turnbull et al. (1974) found a fall in progesterone and a rise in oestradiol during the five weeks preceding labour: this leads to a decrease of the $P E_{2}$ ratio (15:1 at 36 weeks of gestation; $5: 1$ at term). Furthermore it appeared that there was no difference in the plasma concentrations of oestradiol and progesterone before and after the onset of labour. This has also been contîrmed by Mathur et al. (1980).

Csapo et al. (1971) found a significant fall of progesterone after reaching peak values four weeks prior to delivery. In 1975 he published his "see-saw" theory, emphasizing the dominant role of progesterone, counteracting the influences of oestrogens, oxytocin, uterine volume and the foetus.

No change in $\mathrm{PE}_{2}$ ratio was found by Batra et al. (1976). The levels of total oestrogen and progesterone ir plasma increased with advancing pregnancy, and at no time, prior to delivery, was there a significant fall in progesterone or an abrupt rise in oestrogen. 'The $\mathrm{PE}_{2}$ ratio changed from $6.2: 1$ at 33 weeks of gestation to $7.2: 1$ at term. These data are in agreement with the findings of Shaaban and Klopper (1973), Tulchinsky et all. (1972), Mathur et al. (1980). 
An interesting finding of Batra's research (1979) was a relative increase of free progesterone during the second half of pregnancy (ratio total/free progesterone increased from $6 \%$ to $11 \%$ at term). Parker et al. (1979) did not find a decrease of progesterone at the end of pregnancy.

In view of the large body of conflicting evidence there is general consensus of opinion (Flint, 1979) that levels of sex steriods in the peripheral circulation are of limited relevance to the understanding of the onset of term labour.

In cases of (imminent) preterm labour Tamby Raja et al. (1974) and Csapo et al. (1974) found a low PE ratio, compared to a control group. However, the decrease of PE ratio in Raja"s patient-group was caused by at marked increase in peripheral plasma oestradiol levels with normal progesterone levels, whereas in Csapo's inwestigation it was, in fact, a significant lower plasma progesterone concentration which caused the low PE ratio. The work of Cousins al al. (1977) added more conflicting data: he found significantly lower progesterone and oestradiol levels in patients with established preterm labour than in control cases and only a change in PE2 ratio in a small subgroup of the preterm labour patients.

The relationship between sex hormone changes preceding preterm labour and their relation with uterine contractility are further discussed in chapter IV.

\section{PE ratio in the myometriam.}

Realizing that plasma levels do not express what really happens in the target cells, many authors have focused their attention on progesterone and oestrogens concentration in human pregnant myometrium.

Batra and Bengtsson (1978b) have well demonstrated that while at midterm there is a good correlation between plasma and myometrium concentrations for both progesterone and 17-beta-oestradiol, in full term pregnancy this correlation is non-significant for progesterone and weak for 17 -beta-oestradiol.

They suggested that the specific as well as the non-specific binding sites for progesterone, are saturated as pregnancy approaches full term. Furthermore, Batra et al. (1979) described the different $\mathrm{PE}_{2}$ ratios at torm of plasma, decidua, myometrium and placenta $(8.7,112.2$, 61.4 and 370.0 respectively). The conclusion drawn from their data was a lack of correspondence between the plasma concentrations and the tissue concentrations of female sex steroids during pregnancy.

Haukkamaa and Latheenmaki (1979) found no differences in progesterone concentrations neither in myometrium nor in peripheral plasma before and during labour. However, their data showed an increase of oestrone in advanced labour in myometrium and peripheral plasma. This leads to a decrease in $\mathrm{PE}_{1}$ ratio, in both myometrium and plasma.

Ferre al. (1978) showed different levels of progesterone and oestrogens in the inner layer of the myometrium near the placenta from those in other zones, resulting in the lowest $\mathrm{PE}_{2}$ ratio $(20: 1)$ in the onter layer of the antiplacental site of the myometrium. Hilary and Cohen (1981) found a significant increase of oestradiol in the nuclear fractions of the myometrial cells in labour, resulting in a decrease of $\mathrm{E}_{3} \mathrm{E}_{2}$ ratio.

Cohen (1976) believed that a function of the abundantly produced oestriol during pregnancy is to tie up a sufficient number of oestrogen receptor sites, so superseding oestradiol and thus keeping the oestradiol concentration in the nucleus below its threshold stimulatory level. 
Parlati et al. (1982) demonstrated that there are no differences in peripheral plasma and myometrium (outer layer of placental side) of patients before labour, at the beginning of labour and during advanced labour. Oestradiol lewels in plasma did not change in these three groups but myometrium concentrations were significantly higher in the group of labouring patients. Oestrone levels in myometrium did not show differences between the three groups, but surprisingly he noted a decrease of oestrone in peripheral plasma of patients at the onset of labour, in respect to those undergoing elective Caesarean section. These result in a decrease of $\mathrm{PE}_{2}$ ratio in myometrium in labouring patients, in conformity with Ferre's paper, but the PE, in myometrium in labouring patients is not in agreement with the study of Haukkamaa and Lätheenmäki (1979).

Apart from the fact that reported hormone levels in the myometrium show considerable variation, the inaccessibility of the pregnant myometrium limits any potential usefuness of this approach in the prediction of preterm labour.

\section{Corticosteroids}

Many investigators have studied the relationship of maternal and foetal cortisol levels to the characteristics of labour and delivery. This interest has especially risen after identifying the important role of corticosteroids in initiating parturation in sheep (Liggins et al. , 1973; Mitchell, 1979). Also in the human some pathological circumstances, e.g. the association between postmaturity and foetal anencephaly (Anderson et al., 1969; Honnebior and Swata, 1973) and foetal adrenal hypoplasia (Anderson et al. 1971) as well as the correlation between premature delivery and foetal adrenal hyperplasia (Anderson et al. , 1971) have been studied.

In maternal plasma, there is a progressive rise in the cortisol levels with advancing pregnancy (Pokoly, 1973; Murphy, 1973). There was no difference in mean cortisol concentration in late pregnancy, compared to immediate prepartum days (Jolivet et al. 1974).

During labour, on the other hand, a gradual increase was observed in all patients, culminating at the time of birth, and falling during the postpartum hours. There was a steep rise of maternal blood cortisol, uncorrelated to cervical dilatation after spontaneous rupture of membranes (Joliver et al. , 1974).

In cases of elective Caesarean section, significantly lower cortisol levels were found compared to emergency Caesarean sections (Jolivet et all., 1974). These data suggest that the rise of maternal cortisol during labour is due to physical and mental stress. Such a finding has been shown also by Rose et al. (1970) and Raymond et al. (1972) who found that the cortisol rise during muscular activity in adult volunteers was associatced to some extent on the degree of motivation.

Talbert et al. (1973) showed that maternal levels of cortisol were consistently higher than foetal levels, and foetal levels of cortisone were significantly higher than maternal cortisone levels. Murphy (1973) explained this cortisol-cortisone comversion by the 11-betadehydrogenase activity of the placenta, protecting the baby against the biologically active cortisol.

Cortisol levels of the foetus during pregnancy and labour thave also been studied by monitoring amniotic fluid and cord blood levels after birth. At term the levels of cortisol in amniotic fluid were about $10 \%$ of the maternal blood level, but only a weak correlation was found between amniotic fluid cortisol and cord blood levels after spontaneous birth 
(Pokoly, 1973). There was a significant difference between cord blood levels of babies. born waginally or after elective Caesarean section.

Similar results have been found by Sybulski and Maughan (1976 a), who also emphasized the differences in cord blood levels of cortisol between elective and emergency Caesarean section.

It has been demonstrated by Miyakawa et al. (1974) that ACTH does not pass the placenta, and that the development and function of the foetal adrenal cortex is regulated by foetal adreno-corticotropic homome secretion (Buster, 1980 ).

Puolakka et al. (1982) showed significantly higher cord levels of ACTH after waginal deliveries than in elective Caesarean section, indicating that the foetal anterior pituitary is capable of responding to stress during parturition.

Another indication that the increase of the cortisol levels might be a result rather than a trigger of parturition, is the significant correlation between the cord level of cortisol and arterial $\mathrm{pH}$ values after spontaneous and induced labours (Martinsen et al., 1982).

In contrast to these data is the observation of Murphy (1973) who found significantly higher cortisol cord levels after spontaneous onset of labour than after induced labour, suggesting that the human foetal adrenal glands appear to play a role analogous to that of the sheep in intiating labour.

Recently Murphy (1981) reported large amounts of a hitherto unrecognized steroid, originating from the foetal zone of the adrenals during spontaneous term and preterm labour. Murphy suggested that this substance is a 11-hydroxy pregnenolone, a progesterone analogue, competing with progesterone receptors, decreasing the effective progesterone concentration, which in turn would result in increased prostaglandin production, and the onset of labour. Regarding this effect it is important to underline that cortisol was found to be an important enzyme inducer with significant maturational effects on various tissues, such as pulmonary and brain tissue, in the perinatal period (Liggins, 1976).

Sybylski and Maughan (1976 b) found significantly lower cortisol cord levels in preterm babies, with RDS, compared to non-affected neonates. However, whether there was RDS or not, appeared to depend more on the degree of prematurity than on cortisol levels at delivery.

\section{Oxytocin}

Oxytocin is a peptide hormone that is synthesized by specific cell bodies in the hypothalamus and then transported along axons to the region of blood spaces in the posterior pituitary. When released into the bloodstream oxylocin acts on uterine smooth muscle and under appropriate physiological conditions it causes uterine contractions. Oxytocin has been used widely in obstetrics to induce labour and in the post-partum period to control uterine haemorthage.

Because of this long-established use of oxytocin to induce labour in pregnant women, at or near term, it has led to the general bellief that oxytocin has a primary physiological role in the onset of labour. However, after careful study of the oxytocin levels in maternal and newborn plasma, Chard (1973) concluded that the physiological significance of oxytocin during labour was poorly defined.

Vasicka ct al. (1978) found no increase in maternal plasma oxytocin levels preceding labour and recently Sellers et al. (1981) have confirmed this. As has been discussed 
previously, these findings might well be in agreenemt with the chinical evidence of an increased myometrial contractility towards the end of pregnancy when we take into account Garfield"s research and hypothesis about the gap junctions (Garfield et al., 1980b). Sellers et al. (1981) noted higher oxytocin levels in foetal umbilical arteries, compared to venous plasma, suggesting the foetus is capable of producing oxytocin. The fact that levels were lower at Caesarean section than after spontaneous birth suggests that release of the hormone in the foetus occurs particularly during labour, though it may not necessarily be an initiating factor.

Similar results were obtained by Dawood et al. (1978) who suggested that the foetus might be a major source of oxytocin during human parturition.

Increasing oxytocin receptor concentration in myometrium during pregnancy has been shown by Husslein et al. (1982) reaching a top at the onset of labour, term and preterm. Oxytocin influences the myometrium vareceptors only.

A lexandrova and Soloff (1980) showed a direct relation between oxytocin receptors and the ratio of oestrogen and progesterone. Oxytocin receptors in the uterus increase by a rising oestrogen-progesterone ratio and this is probably reflected by the clinical observation of an increasing sensitivity to synthetic oxytocin during pregnancy right up to the onset of spontaneous labour. Both oestrogens and progesterone influence the release of oxytocin in sheep; oestrogens stimulating and progesterone suppressing the release, (Roberts. 1975). However, evidence for a similar mechanism in women has not been reported yet.Soloff et al. (1979) and Alexandrova and Soloff (1980) postulated that labour is initiated when the concentration of oxytocin receptors exceeds a threshold and the sites become occupied by oxytocin in the circulation. Oxytocin receptors are also found in human decidua and amnion. Just like in myometrium the oxytocin receptor concentration in decidua increases during pregnancy (Husslein et al., 1982).

Decidua also has a high capacity of prostaglandin synthesis. Husslein et al. (1982) have shown that in vitro oxytocin causes a significant increase in the production of both Prostaglandin E and Prostaglandin F in decidua and they postulated that oxytocin besicles its contractility activating quality also stimulates the prostaglandin synthesis.

\section{Prostaglandins}

Prostaglandins are hormone-like substances that are believed to play a key role in the regulation of cellular metabolism. Found in almost cvery cell and tissue, these substances have broad regulatory functions in relation to smooth muscle activity. Prostaglandins are 20-carbon carboxylic fatty acids and are synthesized in the body by the cell microsomes from essentiall fatty acids.

The precursor present in food is linoleic acid, a fatty acid with 18 -carbon atoms and two double bonds. Once absorbed, this compound is modified into a 20 -carbon fatty acid with four double bonds, named arachidonic acid. The latter is the substrate for biosynthesis of all prostaglandins of the two series (e.g. E2, F2 $\alpha$ ).

In the body arachidonic acid is mainly incorporated in the phospholipids, present in the cell membrane. It is liberated from the cell membrane under influence of a variefy of mechanical, chemical, endocrine and immunological stimuli; one of the enzymes involved in this process is phospholipase A2, a callecium-dependant lysosomal enzym. Phospholipase A2 has been shown to be present in human uterine tissue (Grieves and Liggins, 1976). 
Biosynthesis of prostaglandins has been shown in myometrium, decidua, membranes, placenta and Whaton'selly (Keirse, 1979).

The most important prostaglandins in respect to uterine contractility are prostaglandin E2 and prostaglandin $\mathrm{F} 2$. Biosynthesis of $\mathrm{PG}$ is inhibited by various compounds. Activation of phospholipase A2 is blocked by corticoids. Prostaglandin synthesis is also inhibited by a heterogeneous group of non-steroidal arti-inflammatory drugs such as acetylsalicyl acid, indomethacin , phenylbutazone, naprosyne. There is strong ewidence that prostaglandins are involved in the mechanism of labour. This evidence is supported by the possibility of inducing labour with exogenous prostaglandin at almost all stages of pregnancy and the well-known uterine contractility imhibiting quality of prostaglandin synthesis inhibitors. There are several problems inherent to the investigations of the role that prostaglandins may play in human labour.

Firstly, prostaglandins are considered as local agents and as such their measurements in biological thid may not represent their intra-cellular concentrations.

Secondly, in the circulation they are rapidy metabolized and actively synthesized, so it is not amazing that conflicting data and conclusions, concerning serum levels of prostaglandins during pregnancy and labour have been published by warious authors (Keirse, 1979).

The concentration of prostaglandins in foetal blood has been studied as well: no significant difference has been found between arterial and venous umbilical plasma.

Concerning the prostaglandin concentration in amniotic fluid, there seems little discussion about thee phenomenons: firstly, prostaglandin levels in amniotic fluid are lower in midpregnancy than at term; secondly, levels are higher during labour than before labour; thirdly, levels increase during labour (Keirse, 1979).

Yet until recently (Keirse et al., 1983) there has been far less evidence for an increase of prostaglandin production prior to the onset of labour. The changes in prostaglandin concentrations in amniotic fluid could be originated from the human foetal membranes, enriched in arachidonic acid (Schwarz et al., 1975).

The data of Okazaki et al. (1981), describing the biosynthesis and metabolism of prostaglandins in human foctal membranes and utcrine decidua suggest a rolo of the foetal membranes in the initiation of the biochemical processes that result in parturition.

\section{Catecholamines}

Ever since 1925 ctecholamines are known to influence the uterus. In 1925, Rucker published his observation of transient relaxation of the uterus after injections of a small amount of adrenaline (Rucker, 1925: cited by Caritis et al., 1979). Subsequent studies revealed a dose and species-dependency of the uterine response to adrenaline. Relaxation as well as contraction of the uterine muscle could be achiewed by the same drug and it was the publication of Ahlquist (1948) which elucidated at first some aspects of the adrenotropic receptors by the suggestion of alpha- and beta-receptors.

Stimulation of the alpha-receptors of the myometrium results in activation, whereas stimulation of the beta-receptors results in inhibition of smooth muscle activity (fig. 3-1). The sensitivity of the receptors is influenced by oestrogens and progesterone: oestrogens potentiate the alpha-receptors, whereas progesterone produces the same effect on betareceptors (Jung, 1981). 
The possible role of catecholamines in triggering human parturition is difficult to assess. Zuspan (1970) studied the urinary excretion of adrenaline and noradrenaline before. during and after labour. The adremaline excetions before and after delivery were found to be in the same range. However, the excretion of noradrenaline in the 24 -hour period after delivery was 2-3 times higher than before labour, and later on in the post-partum period. These data suggest that noradrenaline release has increased in association with labour. However, this might be a consequence of the emotional and physical activity during labour. instead of the cause of the onset of parturition. Because no data are available of investigations in which serum levels of catecholamines have been studied longitudinally during the course of pregnancy no pronouncement can be made whether the emotional and physical activity or indeed the onset of parturition are the cause for the elevated levels of noradrenaline.

Though Zuspan could not define the role of catecholamines in the onset of parturition derivatives of the catecholamines have become the most widely used drug in the inhilbition of theatening preterm labour.

In 1960, Lish et al. reported on the uterine relaxing effects of isoxsuprine bydrochloride in animal experience. Their study suggests that isoxsuprinc has a favourable balance of myometrial versus cardiovascular activity.

In 1961, Bishop and Wouterz reported that of 120 patients in threatening preterm labour treated with isoxsuprine 87 per cent were delayed for more than 24 hours.

In the same year, Hendricks et al. (1961) observed that isoxsuprine inhibited both spontaneous and oxytocin-induced uterine activity.

After the publication of Lands et al. (1967a) gradually more knowledge and insight in the receptor theory conceming adrenergic agents was obtained. Lands et al. made a subdivision in the beta-receptors (beta, and beta 2 ), based on the effector responses to a varicty of catecholamines. As a result more specific catecholamine derivatives have been developed. Examples of these second generation beta ${ }_{2}$-selective agents are fenoterol and ritodrine. 


\section{Pharmacological aspects of Beta $_{2}$-sympathomimetic agents in obstetrics}

1. Introduction

Beta-sympathomimetic drugs are derivatives of the atecholamines. Acetylcholine and catecholamines are the neuro-humoral transmitters of the autonomic nervous system. which includes the craniosacral or parasympathetic system and the thoracolumbal or sympathetic system.

The neuro-humoral transmitter of all preganglionic autonomic fibres, all postganglionic parasympathetic fibres, and a few postganglionic sympathetic fibres is acetylcholine. The adrenergic fibres comprise the majority of the postganglionic sympathetic fibres; here the transmitters are the catecholamines.

The integrating action of the autonomic nervous system is of vital importance for the well. being of the organism. In general the autonomic nervous system regulates the activities of structures that are not under voluntary control and that, as a rule, are functions below the level of consciousness. Thus respiration, circulation, digestion, body temperature, metabolism, perspiration and secretions of certain endocrine glands are regulated, in part or entirely, by the autonomic nervous system and its central connections.

Catecholamines can cause either excitation or inhibition of smooth muscle, depending on the site, the dose and the catecholamine in question.

On the basis of such observations, Ahlquist (1948) proposed the terms alpha- and betareceptors for adrenoceptive sites on smooth museles, where catccholamines produce excitation and inhibition respectively.

Phenylephrine is a typically alpha-adrenergic anine, whereas isoproterenol is a betasympathomimetic amine.

Landset al. (1967a) made a subchassification of the betareceptors in betall fand betareceptors by comparing effector responses (lipolysis and bronchodiatation) to a varicty of catecholamines, which were active at the adrenergic receptor site.

Beta-receptors are present predominantly in myocardium and fat cells, and beta 2 receptors are mainly in uterus, bromchial muscle, liver and striated muscle cells. Detaled lists of responses of effector organs to autonomic stimulation have been composed (Bowman, Rand and West, 1968; Goodman and Gillman, 1975; Essed, 1981).

Beta-receptors enable a number of functions:

heart

coronary arterics

intestinal smooth muscle

adipose tissue

salivary gland
- increase in heart rate, increase in contractility

- relaxation

- relaxation

- lipolysis

- secretion 
Responses that have been labelled beta 2 -receptor mediated, are:

vascular snooth muscte
tracheabronchi
skeletal musele
urinary bladder
gall bladder
liver
pancreas
uterus

- relaxation

- relaxation

- contraction

- glycogenesis

- relaxation

- relaxation

- glycogenolysis

- stimulation insulin release

- relaxation

Howewer, Cartsson and Ablad (1976) suggested that there might be no absolute organ separation for beta- and beta $2^{-r e c e p t o r s, ~ a n d ~ t h a t ~ a ~ p a r t i c u l a r ~ o r g a n ~ m i g h t ~ c o n t a i n ~}$ predominantly beta 1 - but also beta 2 -receptors, or the reverse.

Ariens and Simonis (1976) made a subclassification of the adrenergic receptors on a physiological base; namely the existence of receptor sites for the adrenergic transmitters at the sympatic nerve endings, and the existence of receptor sites for the adrenergic hormone. This resulted in a concept of beta (tramsmitter) adrenergic receptors and beta $\mathrm{H}^{-1}$ (hormonal) adrenergic receptors.

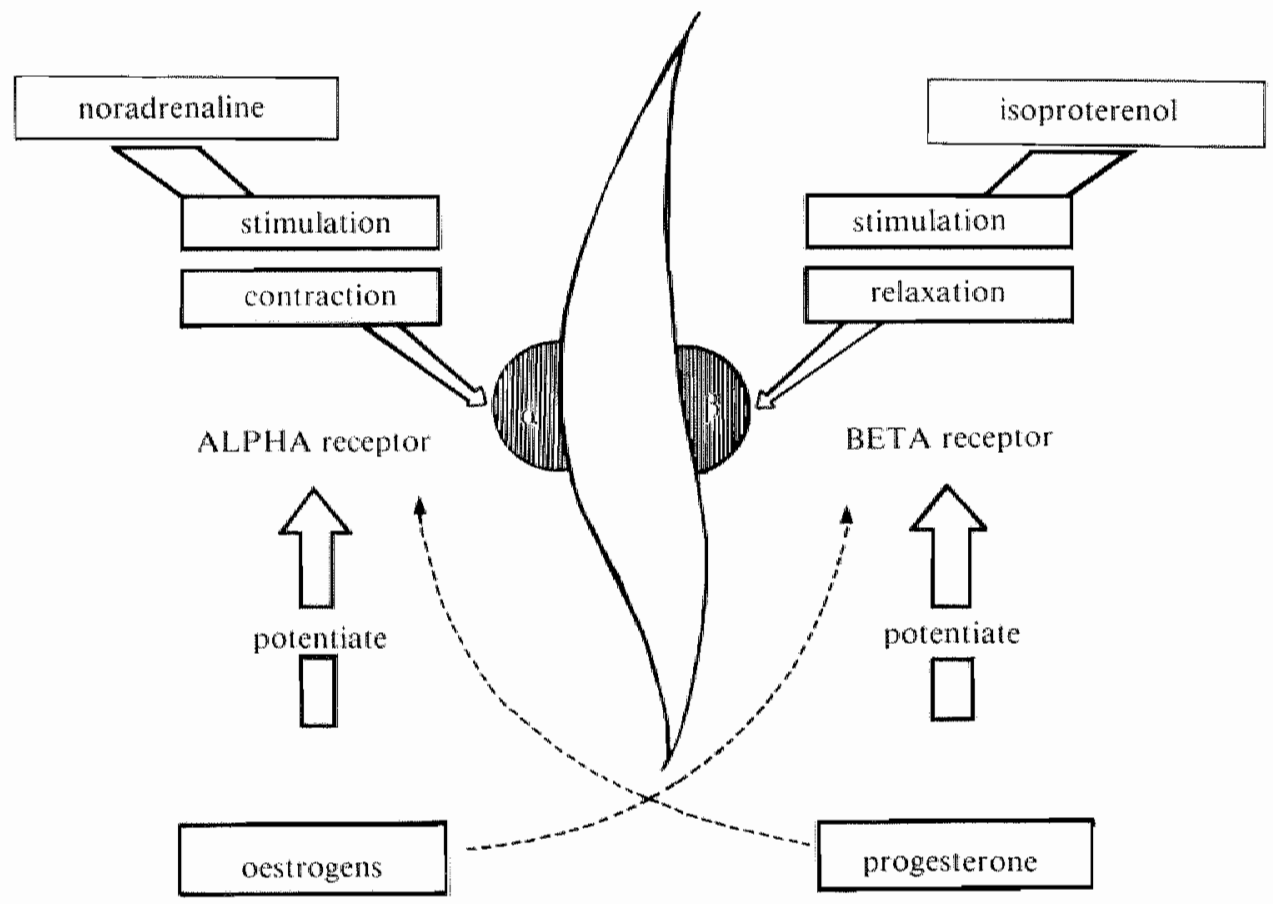

Fig. 3-1: Influence of oestrogens, progesterone and beta-adrenergic agents on the myometrial muscle cell (Jung, 1981). 
According to van Driel et al. (1973), the uterine smooth muscle has no sympathetic innervation, but it still responds well to catecholamines. Using Arièns" theory, this is quite comprehensible.

As well as in the beta beta $_{2}$-classification, in various wissues both adrenergic transmitter receptors and hormonal receptors are found. This selectivity is relstive and determined by the ratio between betar and beta $\mathrm{H}_{\mathrm{receptors}}$, which varies from tissue to tissuc.

The distinction between beta - and beta ${ }_{H}$-receptors parallels to a certain degree the

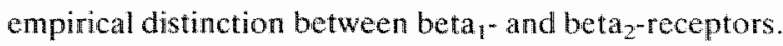

In this thesis the terms beta 1 - receptor and beta ${ }_{2}$-mimetic (drug) will be used, since these terms are still the ones most frequently used in the literature.

The uterus is known to have alpha- and beta-receptors. As mentioned before, the formation of these receptors is under the influence of hormones, especially oestrogens and progesterone. A simplified model for the interpretation of the affects of the catecholamines and the placental steroids on the uterus is presented in figure 3-1 (Jung, 1981).

\section{Drug dosage-Effect Pathway}

Between the administration of a drug and the appearance of its biological effect, there is a sequence of processes, determining the moment, the force and the length of duration of this effect.

This sequence can be divided into three main phases: the pharmaceutical phase, the pharmacokinetic phase and finally the pharmacodynamic phase. The correlation between dose and serum level is mainly determined by the processes in the pharmaceutical and pharmacokinetic phase; the processes in the pharmacodynamic phase actuate the correlation between serum level and biological effect. Schematically the dose-effect pathway is shown in fig. 3-2.

1. pharmaceutical

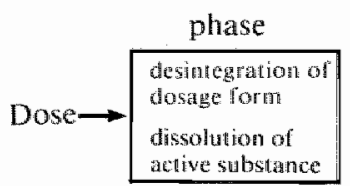

11. pharmacokinetic

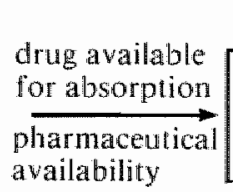

phase
absorption
distribution
metabolism
excretion

III. pharmacodynamic phase

\begin{tabular}{|c|c|}
\hline $\begin{array}{l}\text { drug avalable } \\
\text { for acion }\end{array}$ & $\begin{array}{l}\text { drug recoplor } \\
\text { snteraction }\end{array}$ \\
\hline $\begin{array}{l}\text { biological } \\
\text { availability }\end{array}$ & $\begin{array}{l}\text { inn larget } \\
\text { lissue }\end{array}$ \\
\hline
\end{tabular}

Fig. 3-2: Drug dosage - Effect paihway (A riens and Simonis, 1976).

\section{Pharmaceutical phase}

The pharmaceutical phase concerns the release processes of the active drug from the dosage form, and thus determines the concentration available for absorption.

Although "patient compliance" is not an aspect of the pharmacentical phase, it is an important factor with regard to the pharmaceutical availability. Especially when a drug thas to be administered frequently (because of its short pluarmacological half life) like the beta. mimetic agents, it is well recognized that the reliability of medicine intake will decrease, resulting in a smaller pharmaceutical availability. 


\section{Pharmacokinetic phase}

The pharmacokinetic pliase comprises those processes which play a part in the absorption. distribution, metabolic conversion and excretion of the drug. Especially the three first mentioned processes together defermine the biologicall availability.

\section{Absorplion}

The absorption depends to a high degree on the way of application.

In case of beta-mimetic agents the drug is usually administered via the oral, the subcutaneous, the intramuscular or the intravenous route.

If a drug is administered by the intravenous route, no barriers have to be passed before entering the circulation. As a result there is a fast set-in of the effect, but in general also a comparatively short-lasting effect.

In case of intramuscular application the membranes of the endothelium of vascular and Iymphatic capillaries have to be passed. In general substances with molecular weights over approximately 20 .010 are taken up manly into the lymphatics and those with molecular weights less than 3000 are preferably taken up by the capillaries (Bowman et al., 1968). So in case of beta-mimetic drugs with molecular weights of $300-500$, a haematogenic distribution is usual.

When a drug is administered orally, the mucous mombranes of the gastro-intestinal tract hawe to be passed first, afterwards it is carried via the portal vein to the liver. There is a metabolism process during its intestinal absomption and in the liver the drug is exposed to the enzymatic detoxifying mechanisms of the microsomes of the liver cells.

These two processes result in a so-called 'first pass effect". The ratio with which the liver and the gastro-intestinal tract reduces the biological availability of a certain drug can be demonstrated by comparing the area under the serum curve (AUC) after oral administration with the A.U.C. produced aftem injection into a systemic vein.

Beta-mimetic agents seem to have a large 'first pass effect'. Rominger (1977) calculated this in case of fenoterol and found first pass effect of 64\%. Post (1977) measured a bio. availability of the oral formulation of ritodrine of $30 \%$ of the parenteral preparations, indieating a first pass effect of $70 \%$. He also collected data from the literature and found a first pass effect of $78 \%$ in case of salbutamol and even of $88 \%$ when terbutaline was given orilly. It hits to be stressed, however, that there are great inter-individual and intraindividual differences in the first pass effect.

\section{Distibution}

Investigations carried out in tats by Buchett and Rominger (1972) with tritium-marked fenoterol proved a fast distribution without accumulation except in kidney and liver. There wats no accumulation in adipose tissuc, nor in muscle tissue.

Post (1977) showed that after intra-muscular application the serum levels versus time approached a straight line when expressed on a log-scale, indicating a one-compartment pharmacokinctic model. This central compartment model is in agreement with the results of Buchelt and Rominger (1972).

Transplacental passage has been shown by several authors. In animal experiments, de Han ot al. (1978) demonstrated placental transfer of tritium labelled fenoterol in Rhesus 
monkeys, whereas Kleinhout and Veth (1975) using ritodrine did the same in sheep. Transplacental passage has been proven in human subjects among others by Brazy et at. (1981) and van Lierde and Thomas (1982). Brazy et al. (1981) demonstrated that cond isoxsuprine values averaged $90 \%$ of the maternal serum concentration at the time of delivery. In contrast to Brazy"s results, van Lierde and Thomas (1982) found in case of ritodrine an umbilical wein/maternal vein ratio only $0.30 \pm 0.13$ (mean \pm S.D.).

A special aspect of the distribution is the binding to plasma proteins, mainly albumin. They may be regarded as "silent receptors" or sites of loss (Ariens and Simonis, 1976). After intravenous infusion of tritium labelled ritodrine $32 \%$ of the label was found to be protein-bound, almost exclusively to the albumin fraction (Barden et al., 1980). Only the free fraction of the drug is available for drug action, as well as for metabolism and excretion.

\section{Metabolism and excretion}

Two enzymes play an important role in the inactivation of the catecholamines: the catechol0-methyl transterase (COMT) inactivates the hydroxyl groups on the benzenc ring, whereas the mono-amino-oxidase (MAO) inactivates the groups which belong to the nitrogen atom.

Most beta-mimetic agents used for tocolysis are believed neither to be metabolized by MAO nor COMT. The exact metabolic route for these drugs in the myometrial cells is not certain.

According to the route of administration they are excreted by the kidneys either unaltered or as conjugates; the latter through metabolism in the liver and in the gastro-intestina! tract.

In guinea-pig studies Kords (1977)measured the excretion of tritum-labelled fenoterol after injection of $4.5 \mathrm{mcg} / \mathrm{kg}$ intravenously. The compound was metabolized rapidly, only $10 \%$ of the recovered radio-activity being detectable as non-metabolized fenoterol after 10 min. The identified metabolites largely involved glucoronides.

Studics in human subjects conducted by Buchelt and Rominger (1972), referred by Sas and Kovacs ( 1980 ) have shown that following an oral dose of fenoterol approximately $99 \%$ is excreted as the sulphate ester.

Terbutaline is inactivated and excreted mainly in the form of sulphate conjugate. After orall intake $50 \%$, whereas after intravenous administration $90 \%$ will be eliminated in the urine, the rest in the bille and in excrements (Nilsson et al., 1972).

After orall administration of tritum-labelled ritodrine to healthy mate or non-pregnant female volunteers, 71 to $93 \%$ of the radiogetive label was excreted in the urine (Barden. 1980). The maximum excretion rate was reached within an hour of ingestion of ritodrine. As in animal studies, ritodrine was excreted either as the unchanged parent compound or as the inactive conjugates. After intravenous infusion of tritium-labelled ritodrine, similar excretion kinetics were observed.

\section{Serum levels}

Absorption, distribution, metabolism and excretion are the parameters which determine the relation between serum levels versus time.

Post (1977) collected data from the literature of 4 frequently used beta-adrenergic 
agonists.

In case of terbutahne, maximum serum levels of $6-7 \mathrm{ng} / \mathrm{m}$ were attaned, $90-120$ minutes after oral administration of $5 \mathrm{mg}$. Subcutaneous application of $0.25 \mathrm{mg}$ terbutaline resulted in a peak level of $5 \mathrm{ng} / \mathrm{ml}$ within 30 minutes. The calculated half life was 1.5 hours (Leferink ef al., 1977).

After oral administration of $4 \mathrm{mg}$ Salbutamol maximum peak plasma concentrations of 6-9 ng/ml were achieved in $₫$ to 3 hours. Half life seemed to be about 6 hours (Martin et al., $1976)$.

Rominger (1977) showed plasma peak levels of about $2 \mathrm{ng} / \mathrm{ml}$ after 2 hours intravenous administration of fenoterol $(3.3 \mathrm{mcg} / \mathrm{min})$. The calculated half life was 22 minutes. In animal studies Kords (1977) calculated a half life of 36 minutes in pregnant rats. De Haan et al. (1978) measured half life walues in foctuses of Rhesus monkeys (149-150 minutes) "whereas the maternal half life was 52 minutes.

Ritodrine is the most thoroughly studied sympathomimetic drug with regard to pharmacokinetics in human (Post, 1977; Gandar et al., 1980; van Lierde et al., 1981; van Lierde and Thomas, 1982). All serum determinations were performed by using the same radioimmunoassay technique, as described in the literature by Gandar et al. (1980) and Thomas et al. (1982).

Post (1977) described serum lewels after oral and intramuseular administration of $10 \mathrm{mg}$ ritodrine in four healthy male volunteers. Peak levels were reached rapidly and fluctuated round about 10 and $20 \mathrm{ng} / \mathrm{ml}$, respectively. Half lives of orally administered ritodrine were 1.2 and 14 hours; in case of intramescular application the measured half life was about 4 hours.

Peak levels of $41 \mathrm{ng} / \mathrm{ml}$ were attained 1 hour after continuous intravenous administration of $150 \mathrm{mcg} / \mathrm{min}$ ritodrine.

There was a striking correspondence between (maternal) heart rate and the serum level of ritodrine (fig. 3-3).

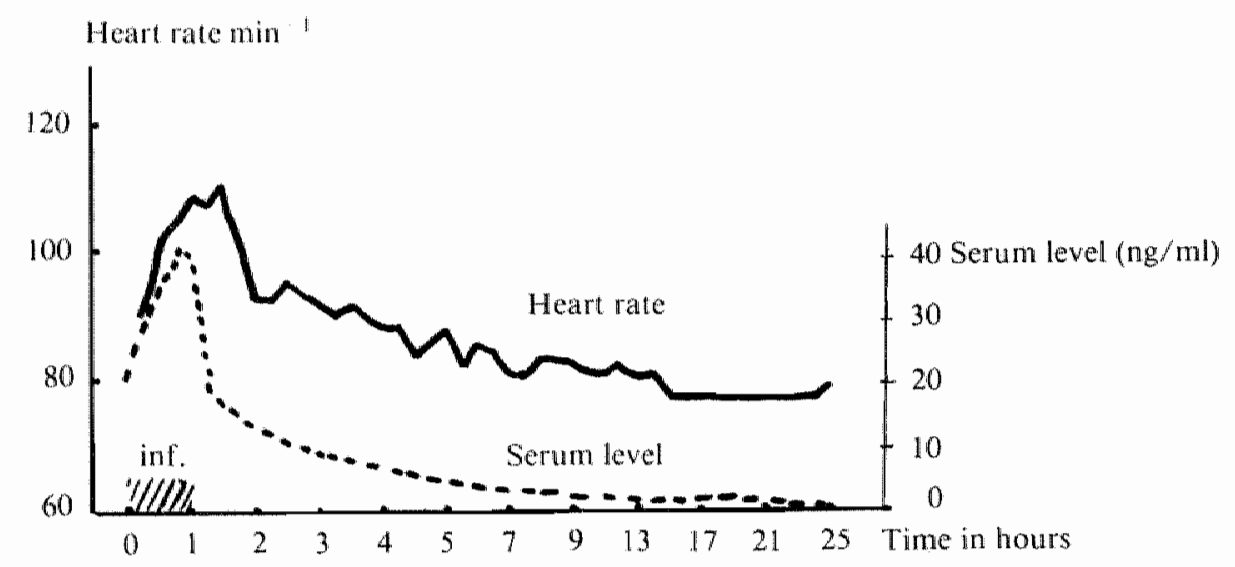

Mean heart rates and serum Ritodrine levels in six healthy females during and following one hour infusion of $0.15 \mathrm{mg} / \mathrm{min}$.

Fig. 3.3: Relation between maternal heart rate and ritodrine serwm levels. (Post. 1977) 
Post did not mention standard dewations of his data. Gandar et al. (1980) republished, but more in detail, the diagrams of Post. Ony small standard deviations have been shown.

Van Lierde et al. (1981) examined serum levels of ritodrine in 4 groups of 10 non-pregnant wolunteers. Patients in group 1 received ritodrine intravenously during $30 \mathrm{~min}$ at a rate of 2 mcgkg body weight/min, followed by $4 \mathrm{mcg} / \mathrm{kg}$ body weight/min again during $30 \mathrm{~min}$. The second group received $10 \mathrm{mg}$ intramuscularly, whereas the 3 rd and 4 th group received 10 and $20 \mathrm{mg}$ ritodrine per os respectively.

In the first group the maximum serum level was $34.9 \pm 5.5 \mathrm{ng} / \mathrm{ml}$ (mean \pm SD) after 60 minutes.

Maximum levels in group 2 were reached within 15 minutes; the peak was $30.7 \pm 8.2 \mathrm{ng} / \mathrm{ml}$ (mean \pm SD).

The third group reached a maximum of $7.7 \pm 4.7 \mathrm{ng} / \mathrm{m}$ (mean $\pm S D$ ) after 45 minutes, whereas group 4 receiving a double dose compared to group 3 had a peak of $23.8 \pm 5.7 \mathrm{ng}$ $\mathrm{ml}($ mean $\pm \mathrm{SD})$ after 60 minutes.

After administration of ritodrine not only the serum levels versus time were studied, but chinical signs and biochemical parameters were investigated simultancously. The diastolic blood pressure showed a statistically significant decrease in relation to the ritodrine serum level.

In conformity with the work of Post (1977) there was a correlation between maternal heart rate and the ritodrine serum levels independent of the route of application.

After the administration of $10 \mathrm{mg}$ ritodrine intravenously or intramuscularly there were significant relations between ritodrine serum levels and glucose, insuline and potassium concentrations.

No such pronounced relationship was found between the systolic blood pressure and the $\mathrm{pH}$ on the one hand and the ritodrine serum levels on the other.

Two papers have been published on ritodrine serum levels obtained during pregnancy (Gandar et at., 1980; van Lierde and "Thomas, 1982).

Gandar et al. (1980) studied the passage of ritodrine through the placental barrier under clinical conditions. Only scanty information concerning the population, the dose and duration of medication and the interval between cessation of treatment and delivery were reported. Nine patients whose pregnancy had procedled up to the 32 nd weck or mote were admitted for preterm labour.

Ritodrine hydrochloride was infused with a rate of $50-300 \mathrm{mcg} / \mathrm{min}$. Other modication was not defined. In all cases the infusion was discontinued when delivery commenced.

Immediately after the delivery blood samples were aken from the umbilical cord and from a maternal vein. The maternal serum llevels ranged from $29.1540 \mathrm{ng} / \mathrm{ml}$. "The mean maternal serum lewel was $241 \mathrm{ng} / \mathrm{m}$. The standard deviation was $61 \mathrm{ng} / \mathrm{ml}$. When supposed that the maximum serum level of $1540 \mathrm{ng} / \mathrm{ml}$ could be chue to an error, and this extreme value was discarded, even then there cxisted a SD of $48 \mathrm{ng} / \mathrm{ml}$ with a mean of $79 \mathrm{ng} / \mathrm{ml}$.

The cord samples showed ritodrine levels, tanging from 19 to $70 \mathrm{ng} / \mathrm{m} /$ with a $\mathrm{SD}$ of 19.4 $\mathrm{ng} / \mathrm{ml}$.

Van Lierde and Thomas (1982) infused 8 pregaant women between 37 and 41 weeks whth ritodrine during 30 minutes with $2 \mathrm{mcg} / \mathrm{kg} / \mathrm{min}$ followed by $4 \mathrm{mcg} / \mathrm{kg} / \mathrm{min}$ during the next 90 minutes. After these 120 minutes an elective Caesarcan section was performed.

Ritodrine levels were obtained from a cubal vein and the uterine vein, as well as from several locations in the foetal compartment. Differences werc found between peripheral 
and uterime blood, probably reflecting the transplacental passage. Although there seems no difference betwen the mean levels in the foetal compartment, the interindividual dispersions are loo large to draw conclusions from these data.

\section{Pharmacodynamic phase}

This interesting phase comprises the drug-receptor interaction in the target tissue.

In case of beta-mimetic drugs the receptor site is believed to be located in or on the cell membrane of the myometrial cell.

The drug-receptor interaction is much more complicated than the classic lock-and-key model. There is a tight interrelation of receptor molecules and their surroundings which may well disturb its specific conformation. Moreover the phenomenon of "down regulation" can be considered as an expression of the non-static behaviour of the receptor: after a prolonged exposure to beta adrenergic drugs the concentration of beta-adrenergic receptors decreases, parallel with its declining response.

The clinical experience that after a certain period of administration of a specific drug the biological effect becomes less expressed, is known as tachyphylaxis and could probably be explained in that way by the phenomenon of "down regulation".

The arug anction is based on the formation of a drug receptor complex, a process that is governed by the mass-action law.

In the induction of a stimulus two parameters are important: the affinity of the drug molecules to the receptors, dominated by the quotient, of the binding coefficient and the dissociation coefficient ( $\mathrm{K} / / \mathrm{K} 2$; fig. 3-4), and the capacity of the drug molecule to activate the receptor, the intrinsic activity, dominated by the quotient of the activation constant and the dissociation coefficient ( $\mathrm{K} 3 / \mathrm{K} 2 ;$ fig. 3-4). The activated receptor will stay in the sensitive state for a limited time period only, after which regeneration has to occur to make the receptor available for renewed stimulation (K5).

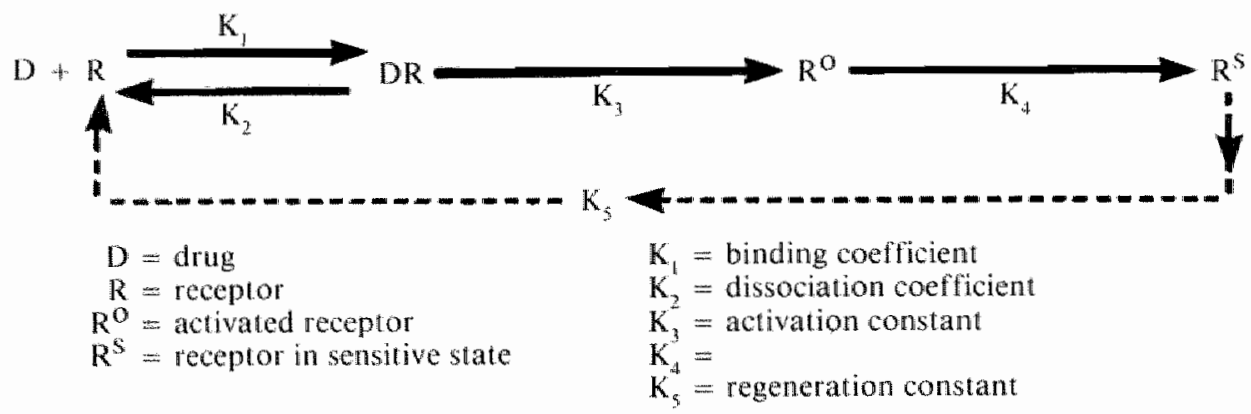

Figure 3-4: Recepror acrivarion after drug exposure (afrer Ariens ans Simonis, 1976).

If $\mathrm{K} 1 / \mathrm{K} 2$ is small, no effect will take place and relatively many receptor places will stay unoccupied.

If $\mathrm{K} 3 / \mathrm{K} 2$ approaches zero, the drug interacts with the receptor without activating it. The drug then acts as a competitive antagonist of compounds for which $\mathrm{K} 3 / \mathrm{K} 2$ is larger.

After an initial peak response an equilibrium will arise and the level of it depends on $K 5$. If $K 5$ is very small, the response will level off to zero and for a certain period of time the 
system will not respond to the drug at all. This mechanism offers another explanation of the phenomemon of tachyphylaxis.

One should be aware of the fact that tachyphylaxis may also result from a loss of the capacity of the effector system to respond, for instance, due to depletion of certain essential ions, or exhaustion of energy supply. In that case the tachyphylaxis will be crossed for all types of drugs that can normally induce a response in the effector system concerned, for instance, for the various types of spasmogens or spasmolytic action via different receptors on the same smooth muscle. The tachyphylaxis due to the slow receptor regeneration wilh be specific for one family of drugs. The clinical fact that, for example, ritodrine has to be administered in a 50-80 fold dose of fenote rol, resulting in a proportionally higher serum level, to obtain a comparable biological effect may be explained by using Ariens modell: in case of fenoterol there has to be a higher affinity and/or intrinsic activity.

\subsection{Structure-activity-relationship}

The biological effect of a drug is determined by the pharmaceutical, pharmacokinctic and pharmacodymamic processes. These processes however, are strongly influenced by the chemical properties of the drug. Small differences in structural formula of apparently similar drugs can cause different teactions.

In case of the sympathomimetic amines beta-phenylethyllamine can be considered as the parent compond, consisting of an aromatic nucleus (a benzene ring) and an aliphatic portion (ethyl amine).

This structure permits substitutions to be made on the aromatic ring, the allpha- and betacarbon atoms, and the terminal amino-group, to yield a great variety of compounds with sympathomimetic activity.

Noradremaline, adrenaline and isoproterenol have OH-groups substituted in the 3- and 4positions of the benzene-ring. Since ortho-dihydroxybenzene is also known as catechol. sympathomimetic amines with these OH-substitutions in the aromatic ring are defined ats catecholamines.

Recently a detailed review, concening structure-activity-relationship has been published by Philips (1980). From this only the main lines concerning beta-agonist activity will be cited. It is important to realize that measuring one effect of a certain sympathomimetic drug is hazardous; most of such drugs have both alpha and beta qualitics. So stuctureactivity relations have to be studied in simplified systems where noradrenaline stores have been depleted by denervation or by drugs such as reserpinc, or where release of stored noradremaline is inhibited by drugs. However, cach of these procedures may have other effects than depletion or inhibition of noradrenaline stores only; they might as well disturb the measurements of the structure-activity-relationship itself.

In general beta-mimetics are structured based on the following principles:

- normally the greatest sympathomimetic activity accurs when two carbon atoms scparate the ring from the amino group. The amino should not be tertiary or quarternary.

- climination of either phenolic group of the benzene ring decreases the sympathomimetic activity.

Changes in the amino group may lead to an increase of beta-activity

- increase in the size of the $\mathbb{N}$-substituent 
- adding an aromatic ring on the alkyl chain, especially when polar groups are attached to the ring

- adding some elaborate variations of the amine side chain.

Changes on the aromatic tring:

- changes from ortho- into meta-position of the 2 OH-groups increase betay-selectivity; especially after oral administration the action has a longer duration.

- some nonphenolic phenylethanolamines (halogen-substituted amino phenyle thanolamines) have shown betay-selectivity.

Side chain substitution:

- substitution on the alpha carbon atom blocks oxidation by $\mathrm{MAO}$, thus greatly prolonging the duration of action.

The parent compound, the catecholamines and some commercially available betamimetic agents are listed in table $\| I-1)$

Table III-1: Chemical structures of some sympathomimetic drugs.

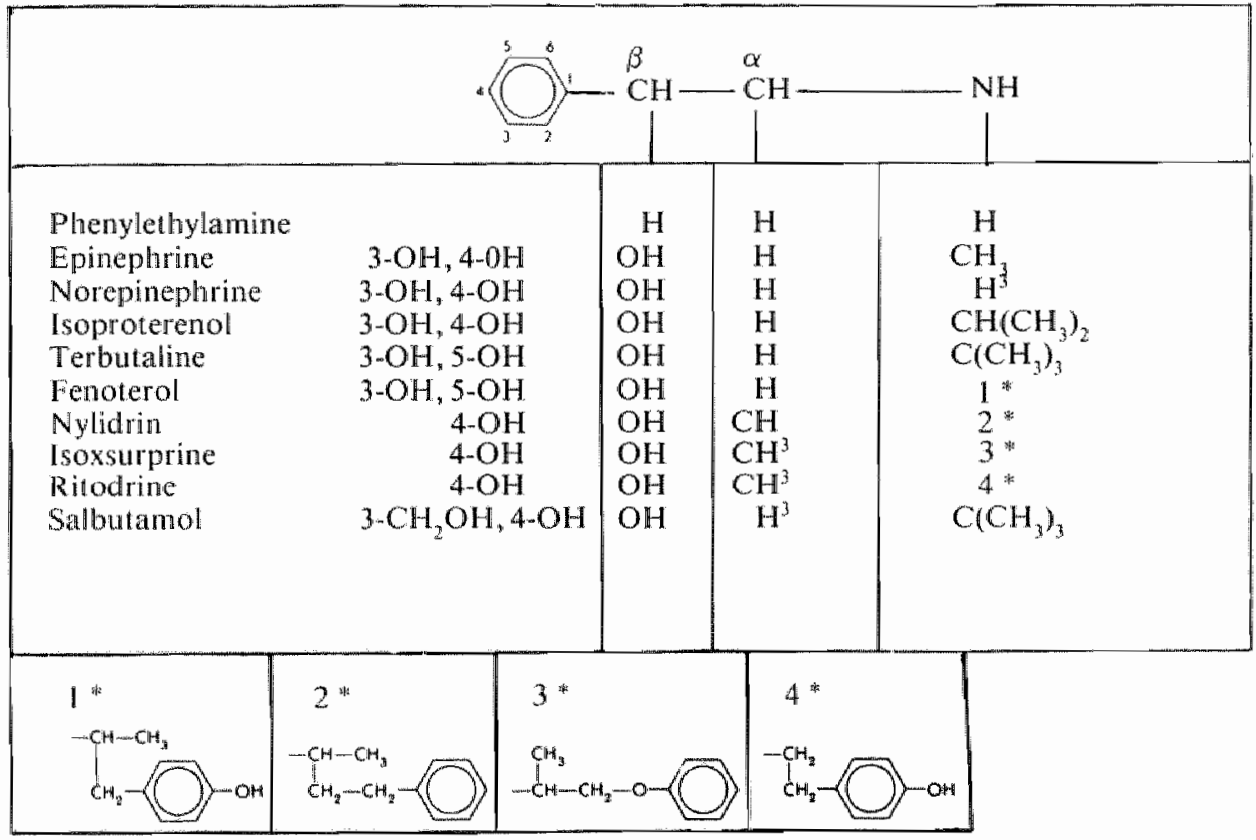

\subsection{Mechanism of action on uterine tissue.}

The relationship between the actin-myosin interaction, myosin phosphorylation, cAMP regulation of myosin fight-chain kinase and the effect of catecholamines on adenylcyclase activity has been described previously and provides a basis for the concept of the myometrial "tocolytic pathway".

Beta-adrenergic agonists exert their effects through their binding to receptors. It has been discussed before that the effect of the sympathomimetic agents on the uterus is influenced by the hormonal state. The in vitro investigations of human myometrium showed that 
oestrogens sensibilize the alphameceptors and make it possible for the catecholamines to induce muscle contractions. Progesterone dominance leads to the sensibilization of the beta-receptors and catalizes the muscle-relaxing effect of the betasympathomimetes (Klöck. 1977).

The fact that the beta-receptors are closely linked with the adenylcyclase enzyme seems certain (Sas and Kovacs, 1980).

Adenylcyclase has been shown to be present in the cell wall of practically all kinds of tissue. Adenylcyclase of a specific tissue is only sensitive for a particular trigger like a hormone or a drug (Robinson et al. 1971). Adenylcyctase is passing on a first "messagc" to a non-specific "second messenger": CAMP.

The effect of CAMP depends on the kind of the stimulated cell.

As an effect of cAMP the activity of membrane-bound enzymes, known as kinases is stimulated. This results in a considerable increase of calcium content of the microsomal fraction of the uterus muscle cell and at the same time, the free calcium level of the myoplasm decreases (Rasmussen and Tenerhouse, 1968). Furthermore, myosin light-chain kinase is inhibited by phosphorylation through the action of a AMP-mediated protein kinase (Huszar, 1980). These two processes contribute to muscle relaxation.

The essential role of AMP is discussed by Kords (1977), who found clevated CAMP lovels without diminution of contractions after administering fenoterol in the oxytocin-stimulated uterus of pregnant rats.

This inconsistency was already noted by Polacek and Daniel (1971), as cited by Sas and Kovacs (1980). They caused relaxation in isolated rat uterus with isoproterenoll treatment while in the meantime a rise of CAMP was observed. As an effect of propranolol, uterine contractions occurred together with a further increase in the CAMP level.

Harbon et al., (1982) noted that both isoproterenol and prostaglandin could increase intracellular cAMP level with opposite actions.

Falkay et al. (1978) demonstrated in vitro in the microsomal fraction of pregnant myometrium that isoxsuprine in a low concentration induces biosynthesis of prostaglandins. According to these examinations, slight stimulation of the beta-receptors of the human myometrium activates not only the adenylcyclase but also the prostaglandin synthetase system. This interaction could be an cxplanation for the rebound cffect observed occasionally in beta-sympathomimetic treatment.

\subsection{The biological effect on the pregnant uterus}

As described before, the mechanism of action of beta-mimetic drugs on uterine tissue is relaxation of the myometrial muscle cell; the desired biological effect is relaxation of the uterus. However, this is not achieved in all patients, treated with beta-mimetic agents. The efficacy of these drugs has been the subject of a large amount of research, cspecially since these drugs are commercially available. Most reports of the use of beta-mimetics for the treatment of preterm labour claim sucess. Furthermore, when compared to the therapeutic alternatives in the control population, the beta-mimetic agent is usually better. Results in favour of beta-mimetic drugs have been shown in the compatrison of ritodrine versus placebo (Wesselius - de Casparis et al., 1971); cthanol (Liduersen et al., 1977; Fuchs, 1976); chlordiazepoxide (Sivasamboo, 1972); terbutaline versus placebo 
(Ingemarsson. 1976) and isossuprine versus placebo (Csapo and Hercze, 1977 ).

Unfavourable reports have been published by Sims el al. (1978) (salbutamol versus alcohol). Spellacy et al. (1979) (placcbo controlled riodrine investigation). Falck Larsen et al. (1980) (placebo controlled ritodrine investigation) and Miller et al. (1982) (terbutaline versus magnesium sulfate).

The validity of a nuber of these trials has been questioned in the literature (Hemminki and Starfield, 1978). To be able to judge the published reports with regard to the efficacy of betamimatic agents it is obligatory to consider the conditions under which the investigations were carried out. A clinical trial to investigate the efficacy of a drug should fulfil a number of criteria before definite proof of efficacy is evident (Eskes and Essed, 1979). In their opinion a clinical trial should be prospective, double blind, randomized, and allocated; the doses and routes of medication, as well as other medication or measures should be mentioned; drug levels should be monitored; patients who are included and excluded from the trial should be described and finally proper statistics should be applied.

The above "Ten Commandments" (Eskes and Essed, 1979) were adhered for the investigation reported in chapter V and VI. 


\section{CHAPTER IV}

\section{The predictive value of uterine contractility and the serum levels of progesterone and oestrogens with regard to preterm labour}

\subsection{Introduction}

Up to now no single criterion is recognized as a parameter with predictive value regarding the onset of preterm labour.

Research has been undertaken to elucidate a possible relation between the onset of (preterm) labour on the one hand and socio-cconomic or bio-physical parameters on the other hand.

The work of Fedrick and Anderson (1976), Erickson and Bjerkodal (1978), Newton et al. (1979), Creasy et al. (1980) comprises these socio-conomic aspects associated with spontaneous preterm birth.

As a result of these studies preterm birth prevention programs have been started (Newton et al. 1979; Herron et al., 1982). Newton et al. (1979) found the level of psycho-social stress in pregnancy to be particularly high in mothers whose babics were born prematurely.

Patients with an obstetricall reason for (threatening) preterm birth "were excluded from the study, but only scanty information about these exclusion criteria have been mentioned. The data of Herron et al. (1982) indicated that the preterm delivery prevention program yielded very favounable results during the first year of its existence.

A physical parameter, well recognized as instrumental in the onset of labour, is uterine activity. However, sometimes pationts attend the maternity ward with a short-lasting on even without a history of uterine contractions but with a more or less fully dilated cervix. In almost all cases tocodynamometry discovers regular uterine activity. So the subjective experience of uterine contractility does not always cotrespond with the objectivated uterine activity.

To date, no well-designed investigation regarding the predictive value of uterine contractility - wither objectively measured by tocodynamometry or subjectively reported by patients - thas been published.

Uterine activity after a woman has been exposed to oxytocin has been used as a prognostic tool to predict preterm labour. Takahashi et al. (1980) showed that thene was an increased sensitivity to oxytocin in the group of patients who delivered preterm and a decreased sensitivity in the group of patients who delivered postterm, both compared to the group of pationts who delivered at term.

Only a fow studies have been undertaken in an attempt to compose standard curves of uterine activity during pregnancy.

Zahn (1978) measured the uterine activity longitudinally during uncomplicated pregnancies in primigravidae as well as in multigravidac. The results of his investigation may probably 
be used as standard curves for physiological and pathological uterine activity. The registretions were performed ambulatory. However, the conditions among which the clinical diagnosis "threatening preterm labour" was made, were different from those under which $Z$ ahn conducted his study. So it may be incorrect to use his data to detect preterm labour.

Koepcke et al. (1976) compared wterine activily in nomal cases with a high risk group and to a group of (successfully) treated patients with betamimetic drugs because of threatening preterm labour. In the later two groups uterine activity was significantly higher than in the first group.

A second physical parameter investigated to test its predictive value in case of threatcning preterm labour is the phenomenon of the rheobase (Kubliet al., 1977; Fetichtinger and Altman, 1981). The underlying thought is that the onset of parturition is not a single process of the uterine muscte alone, but is part of a diffuse neuro-humoral change in the entire organism (Jung et al., 1971). The hope that by measuring the rheobase in an easyly investigatable muscle, for example the anterior tibial muscle, would inform about a threatening preterm labour, has been shown to be too optimistic. Accordingly, the "Heidelberg score" (Kubli et al., 1977), composed of medical history and obstetrical findings, pelvic score according to Bishop, painful contractions, measured contractions and the rheobase, has not become a generally accepted and clinically used instrument. Homonal parameters have been investigated thoroughly, not only as a predictive tool to diagnose threatening preterm labour, but especially to confirm the well-being of the foetus. Chapter II of this thesis has reviewed studies on hormonal profiles during pregnancy.

There seems to be agreement about the fact that progesterone has an uterine contractility inhibiting effect, whereas oestrogens are supposed to stimulate uterine contractility (Csapo, 1975; Batra, 1979; Jung et all. 1981).

This could indicate that there should be less uterine activity if high progesterone levels are present and the reverse situation should apply in case of high oestrogen serum levels. The ratio of progesterone and oestrogen (the PE ratio) is the subject of a continuing controversy (Flint, 1979), especially when the PE ratio is considered during the period prior to parturition.

Therefore it is remarkable that no papers regarding the relation between uterine activity versus progesterome, oestrogens and/or PE ratio have boen published.

The $E_{3} E_{2}$ ratio has been studied in the nuclear fraction of myometrial cells and the importance of a decreasing ratio has been emphasized by Cohen (1976) and Hilary and Cohen (1981). If this decreasing $\mathrm{E}_{3} \mathrm{E}_{2}$ ratio in the nuclear fraction is a result of changing serum levels of thesc homones, then it might be possible to find deviated values of these hormones in patients with preterm labour.

The questions in this study were threefold:

- how cxactly do patients experience uterine contractions compared with those which can be recorded by external tocodynamometry,

- is there a correlation between measured uterine activity and the $P E_{2}$ ratio or $E_{3} E_{2}$ ratio in peripheral serum.

- do patients with threatening preterm labour have a different $P E_{2}$ or $E_{3} E_{2}$ ratio from 
women with uncomplicated pregnancies.

Therefore a longitudinal, prospective study was undertaken in which uterine contractions were measured objectively; subjectively experienced contractions were recorded and progesterone, oestradiol and ocstriol were determined.

It was hoped that by composing standard curves of uterine activity and homonal profiles in the preterm period of uncomplicated pregnancies these questions could be answered and that exceptional values would lead to early detection of pregnant women at high risk for preterm labour.

\subsection{Patients and methods}

Between May, 1981 and September. 1981 eighty healthy pregnant women participated in a prospective trial. The patients were entered in a consecutive manner. Patients who had an uneventful pregnancy without the threat of preterm labour made up the standard group. whereas the patients for whom tocolytic therapy was indicated formed the pathological group.

Women included in the trial were volunteers who answered the following eriteria:

- primigravidae

- first antenatal clinic visit before the 25 th weck of pregnancy

- no uncertainty of dates

- singleton pregnancy

- maternal weight less than $100 \mathrm{~kg}$ (at the onset of the investigation)

During a pilot study it became clear that it was more difficult to motivate multigravid women to attend the maternity ward for more frequent visits necessary for the imvestigation than primigravidae, so it was decided to perform the study in primigravidae only.

Certainty of gestational age was based on a history of regular menstrual periods and a certain first day of the last normal menstrual period, and/or based un wonographical measurements in early pregnancy.

These women were seen biweekly from the 25 th week until the 31 st week of pregnancy and once a week from the 32nd week up to the 37 th weck of pregnancy. During these visits, apart from the routine mcasurements of bodyweight, blood pressure and fundal height, a blood sample was drawn and a cardiotocogram was performod.

As much as possible the patients were recorded under similar conditions to avoid the influence of diurnal variations. The registrations and the blood sampling took place between $9 \mathrm{a} . \mathrm{m}$. and $4 \mathrm{p}, \mathrm{m}$. and therefore the diurnal variations were presumed to be of minimal importance, according to Zahn (1980) and Compton et al. (1979).

The registration lasted one hour while the woman was in left tilt position. The dewice usod. was an adjusted Hewlet Packand Tocograph, placed in a such a position that it was impossible for the woman to sea the registration. The adjustment consisted of a special button which allowed registration of subjective uterine activity after being pressed by the woman.

Afterwards the CTG registration a blood sample was collected from a cubital vein, immediately centrifugated and stored at $-24 \mathrm{C}$ untill assays were performed to establish the serum level of progesterone, 17-beta-oestradiol and oestriol. 
The women were followed up to the 37 th week of pregnancy or until they experienced threatening preterm labour (i.c. painful regular uterine contractions and/or rupture of membranes). The latter women were discarded from the standard group and entered the pathological group.

Initially the treatment consisted of bedrest and observation. When uterine contractions did not decrease, intrawenous nitodrine therapy was started.

In none of the cases treatment was started or the diagnosis "threatening preterm labour" was madc on the base of the routine CTG registration!

Uterine activity was objectivated by CTG registration. The speed of registration was $2 \mathrm{~cm} /$ min. A contraction was defined as an elevation of more than $10 \mathrm{~mm}$ over the level of the baseline and lasted for at least 30 seconds.

All hormone levels were determined in duplicate by means of commercially available radioimmunoassay procedures. In case of 17 -beta-oetradiol kits of Würenlingen, Radio Isotopen Service, E.I.R. was used; progesterone was determined by Farmos Diagnostica Progesterone 125 I Radioimmunoassay kits and total oestriol by means of Oestriol II RIA Amersham kits.

Because of the expected high hormone levels prior to the determinations, the sera were diluted with male serum in case of 17-beta-oestradiol and oestriol, and with normal saline for progesterone.

The interassay coefficient of variation, expressed in percentage, were in case of the oestradiol $6.9 \%$ (mean: $59.3 \mathrm{nmol} / \mathrm{l}$ ) and $7.4 \%$ (mean: $47.1 \mathrm{nmol} / \mathrm{l}$ ), in case of oestriol $6.0 \%$ (mean: $527 \mathrm{mmol} / \mathrm{l}), 5.0 \%$ (mean: $297 \mathrm{nmol} / \mathrm{l}$ ) and $7.6 \%$ (mean: $82.6 \mathrm{mmol} / \mathrm{l}$ ) and in case of progesterone $6.1 \%$ (mean: $523 \mathrm{nmol} / 1$ ) and $7.0 \%$ (mean: $346 \mathrm{nmol} / \mathrm{l}$ ).

The cross reactions for progesterone, oestradiol and oestriol have been shown to be less. than $1 \%$.

\subsection{Results}

The standard group consisted of 71 women who had an uneventful pregnancy and subsequently gave birth to healthy infants. The mean age of these patients was 25 years $(\mathrm{SD} \pm 3.6)$. The mean weight was $63.3 \mathrm{~kg}$ (SD \pm 13.5$)$. The mean duration of amenormoca at delivery was 40.2 weoks ( $\mathrm{SD} \pm 2.1)$.

The pathological group consisted of 9 patients $(11.3 \%)$ and showed no difference in age and weight in comparison with the standard group. These patients experienced painful contractions with concomitant findings at vaginal examination and it was thought that medical intervention was indicated.

The mean duration of amenorrhoea at the onset of the preterm threat was 32.0 weeks (SD 2.1).

The treatment consisted of bedrest and betamimetic drugs. The mean duration of ancnorrhoea at delivery of this pathological group was 36.0 weeks $(S D \pm 2.5)$.

\section{Relation between subjectively experienced uterine contractions and objectivated uterine contractions}

As stated in the introduction of this chapter, there may be no good correlation between 
the contractions recorded cardiotocographycally and the sensations experienced as contractions by the women.

Uterine activity as recorded by extemal tocodynamometry has been compared with subjectively experienced contractions (fig. 4-1).

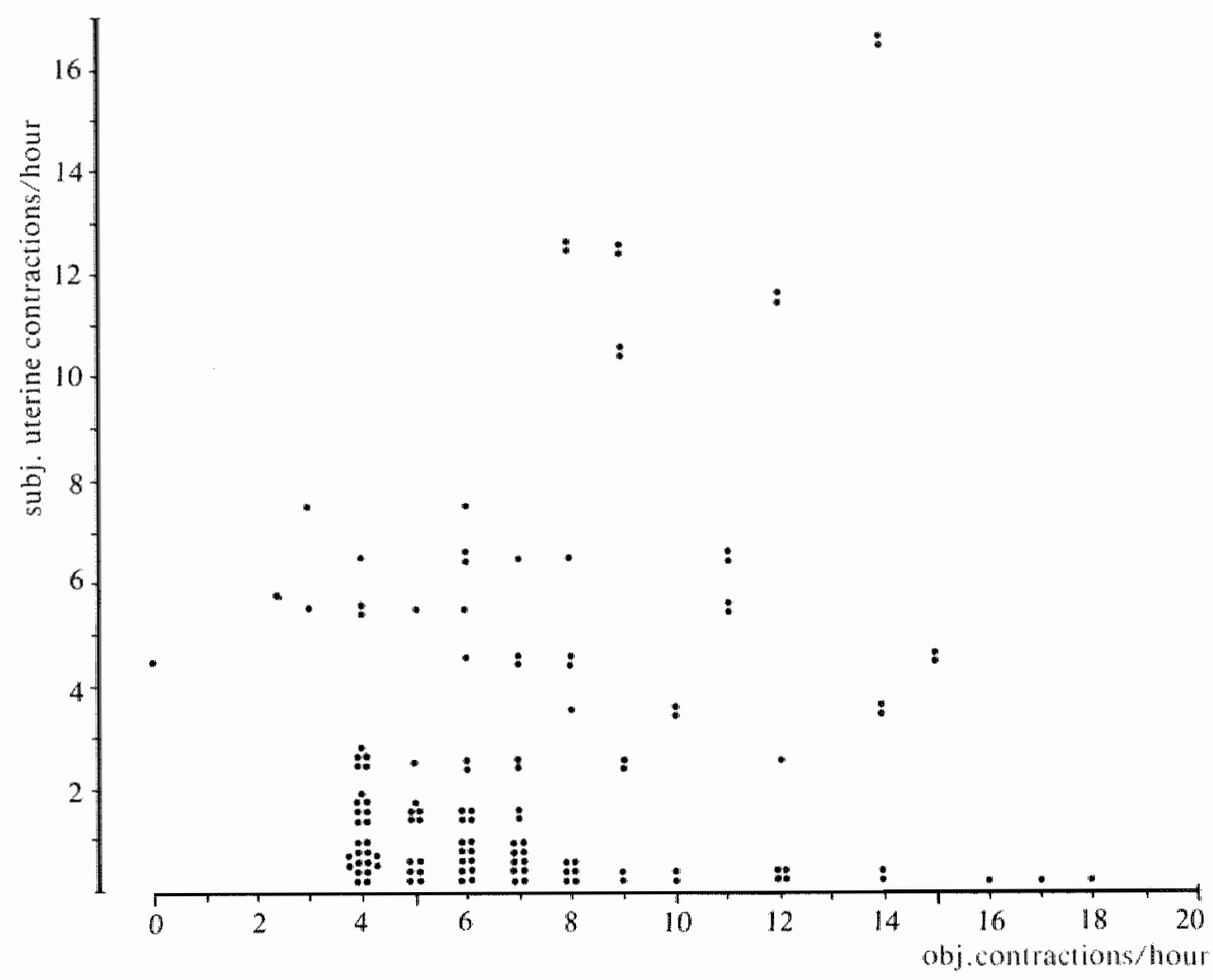

Fig. 4-1: Relation between subjective and objectivated uterine activity.

It has to be stressed that only the experience of the contractions is registrated the that the intensity of the contractions has been left out of consideration.

No marks have been plotted in fig. $4 \times 1$ in the area below a frequency of 4 registrated contractions per hour. This concerned 441 observations. Each point represents one observation.

A correlation cocfficient of 0.41 was found, andicating that there is indecd a poor relation between subjective and measured uterine contractions in primigravidac. With increasing frequency of contractions the women's own observation was found to be less sensitive than external tocographic measurements.

Relation between uterine activity versus progesterone, oestradiol, $P E_{2}$ ratio and $\mathrm{E}_{3} \mathrm{E}_{2}$ ratio

To express those relations, the so-called box-and-whisker plot (Tukey, 1977) was used. The box-and-whisker plot is a graphical device to display differences between wo or more 

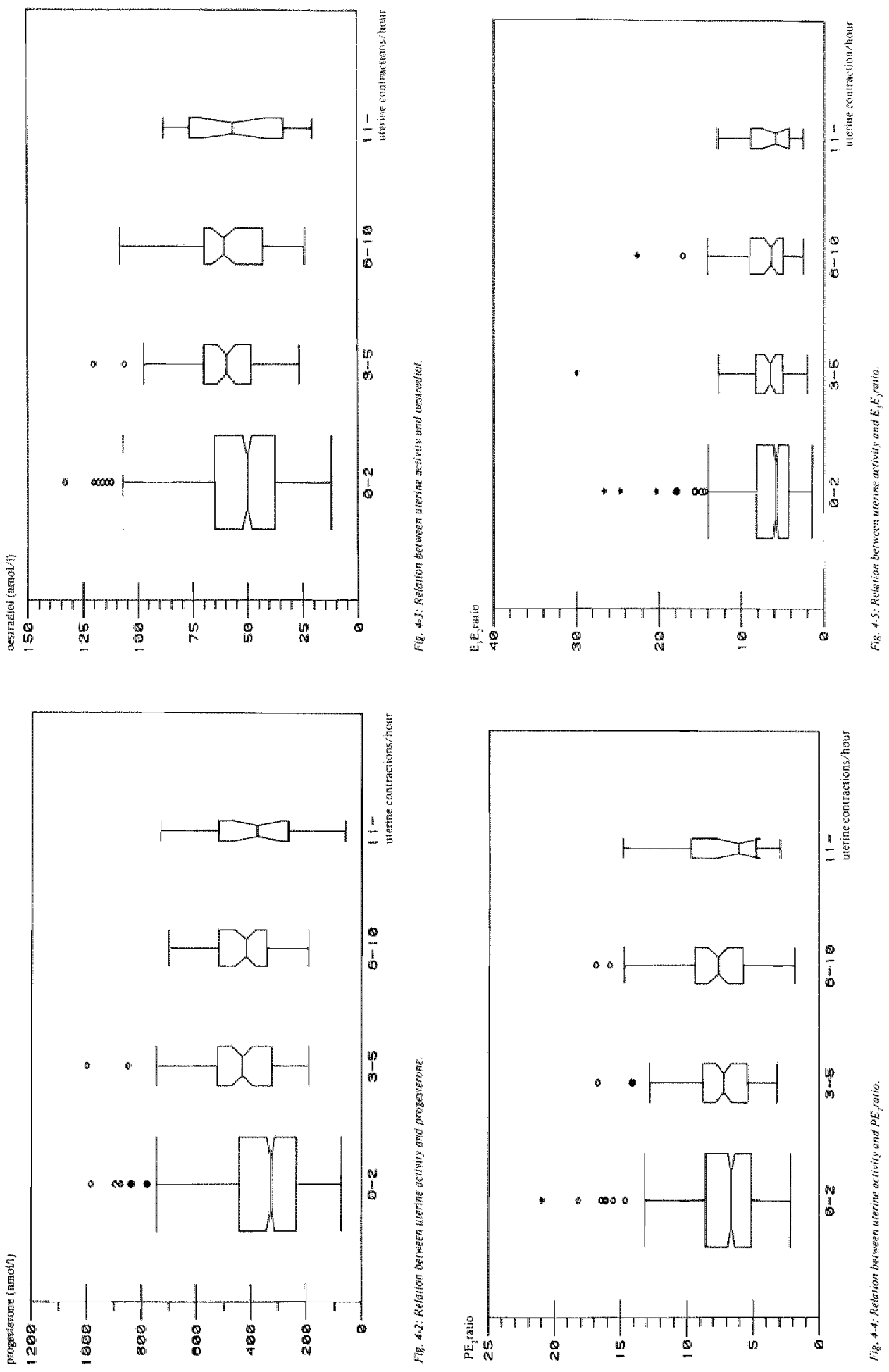

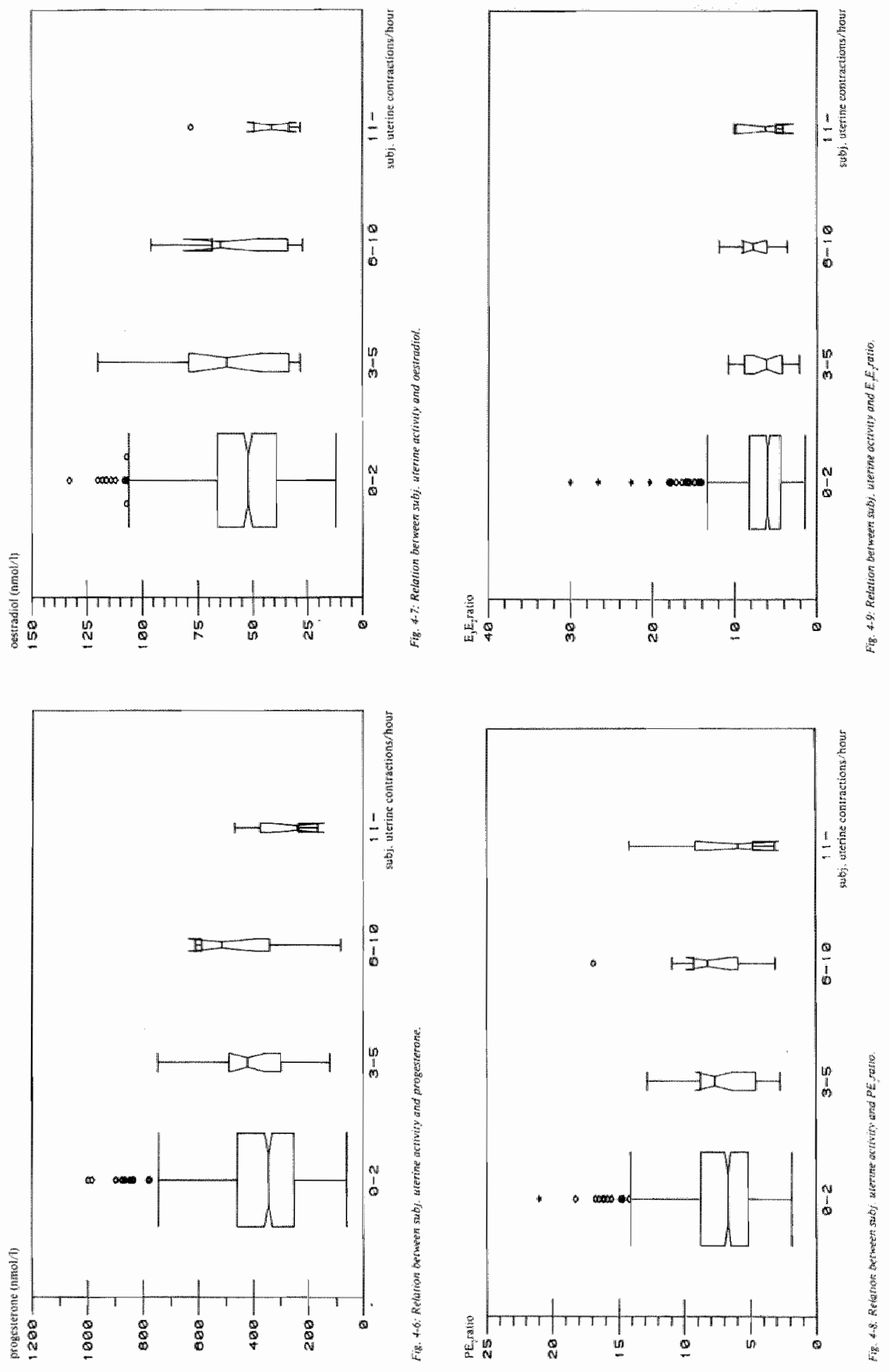
groups. In the present sudy a division in 4 groups was made. This division was based on uterine contractions per hour. The limits were chosen on clinical, arbitrary motives. The basic configuration of a box-plot shows the middle $50 \%$ of the sample as a box and marks the extremes at either end with a horizontal line, connected with the box. The line through the box represents the median of the sample..

Refinements have been used such as the presentation of "owtliers" (Tukey, 1977). The circles indicate values just outside the range and the asterisks the values far out of range. Further refinements are the notched interyals around the median and the adaptation of the width of the box to the sample size (McGill et al. 1978).

The medians of the two samples whose notched intervals do not overlap can be said to be significantly different at roughly 5\% level (McGill et al., 1978).

The correlation coefficient used is the Pearson correlation coefficient.

The relation of measured uterine activity versus progesterone is shown in fig. 4-2 (correlation coefficient: 0.29 ); versus oestradiol in fig. 4.3 (correlation coefficient: 0.16 ); versus the $P E_{2}$ ratio in fig. $4-4$ (correlation coefficient: 0.25 ) and versus $E_{3} E_{2}$ ratio in fig. 45 (correlation coefficient: 0.21 ).

Similar relations were investigated for the uterine activity as experienced by the women. Fig. 4-6 represents the relation between subjective uterine activity versus progesterone (correlation coefficiont: 0,10 ), fig. $4-7$ versus oestradiol (correlation coefficient: 0. II); fig. $4-8$ versus $P E_{2}$ ratio (correlation coefficient: 0.31 ) and fig. $4-9$ versus $E_{3} E_{2}$ ratio (corratation coefficient: 0.25$)$.

Neither with respect to the measured, nor to the experienced uterine contractions, good correlations were found regarding the investigated hormonal profilles.

\section{Comparison of the measured parameters of the pathological pregnancies and those of the uncomplicated pregnancies}

The figures 4-10,4-11,4-12,4-13 and 4-14 express the course of the moasured uterine activity, the serum levels of progesterone and oestradiol and the calculated $P E_{2}$ and $E_{3} E_{2}$ ratio during the course of pregnancy. In these figures the unintertupted lines represent the mean walues of the unconplicated cases; the dotted lines represent the mean $\mathrm{SD}$ value and the dashed lines the mean valluc $\pm 2 \mathrm{SD}$.

The arrows represent the mean $\pm S D$ of the pathological group. The figures atlong the arrows indicate the number of patients in the parhological group at that particular duration of amenorthoea. After the 33 rd week of pregnancy, because of the small numbers, these arrows are replaced by asterisks. Each asterisk then represents the actual value of one patictut.

The "squares" represent the latest value of a patient in the pathological group before betamimetic treatment was started. These samples were obtained within 12 hours before the onset of therapy.

In case of uterine activity these latest values are not plotted, because they run out of scale (all 9 patients had at least 15 contractions per hour). 


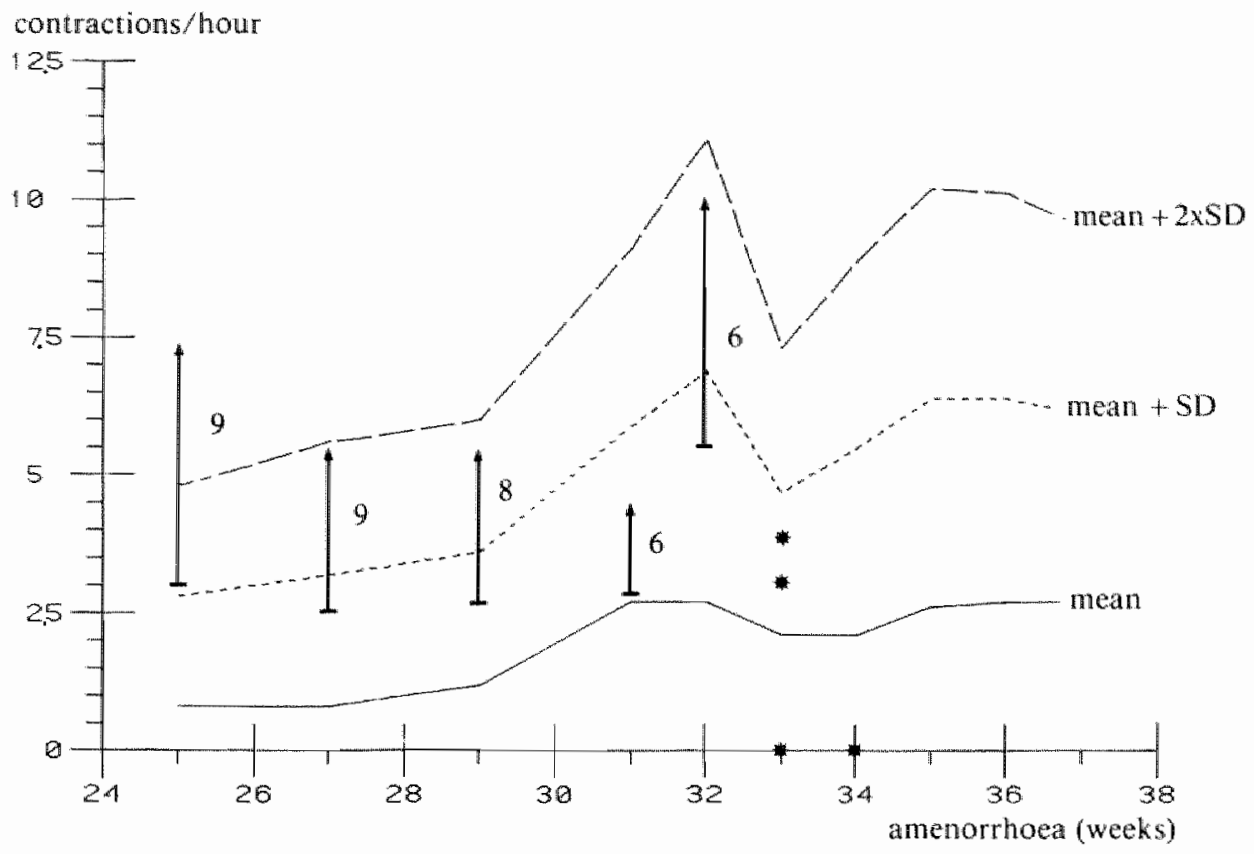

Fig. 4-10: Uterine activity during the preterm period.

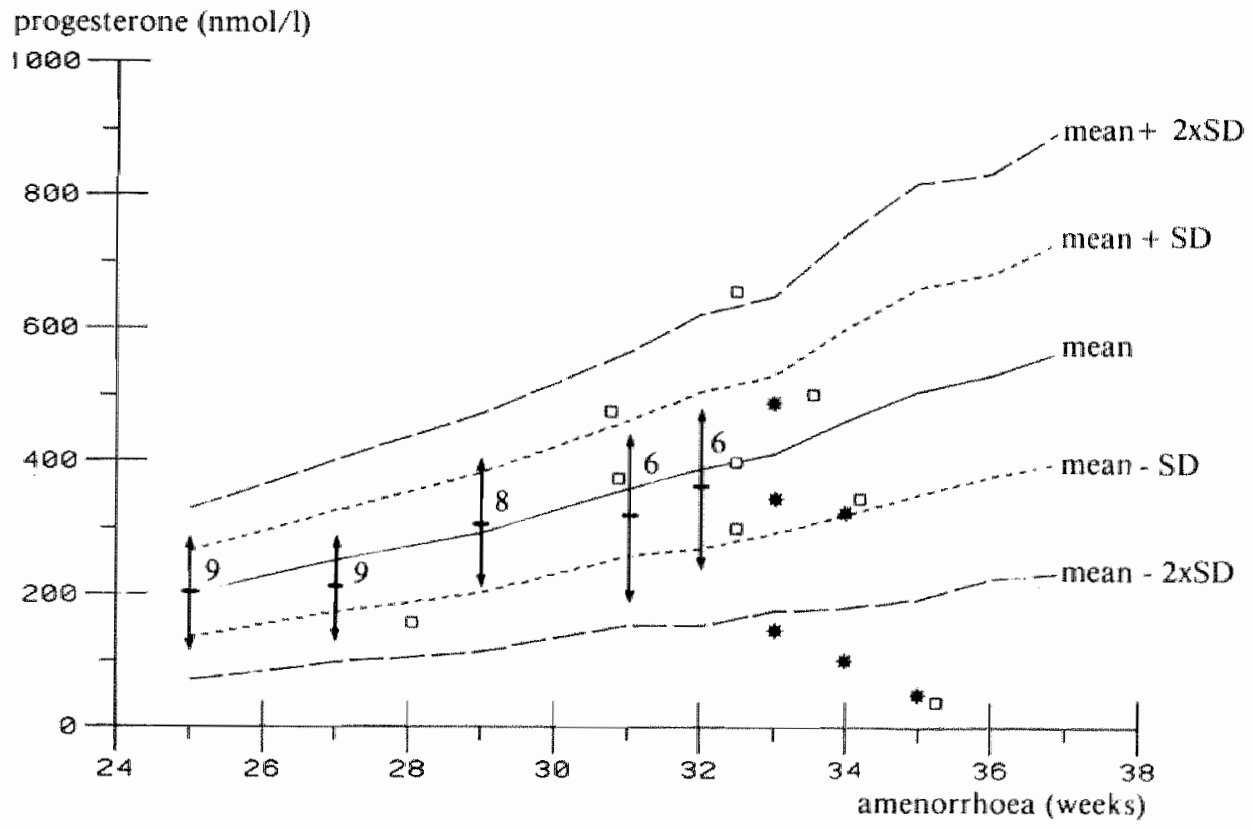

Fig. 4.11: Progesterone during the preterm period. 


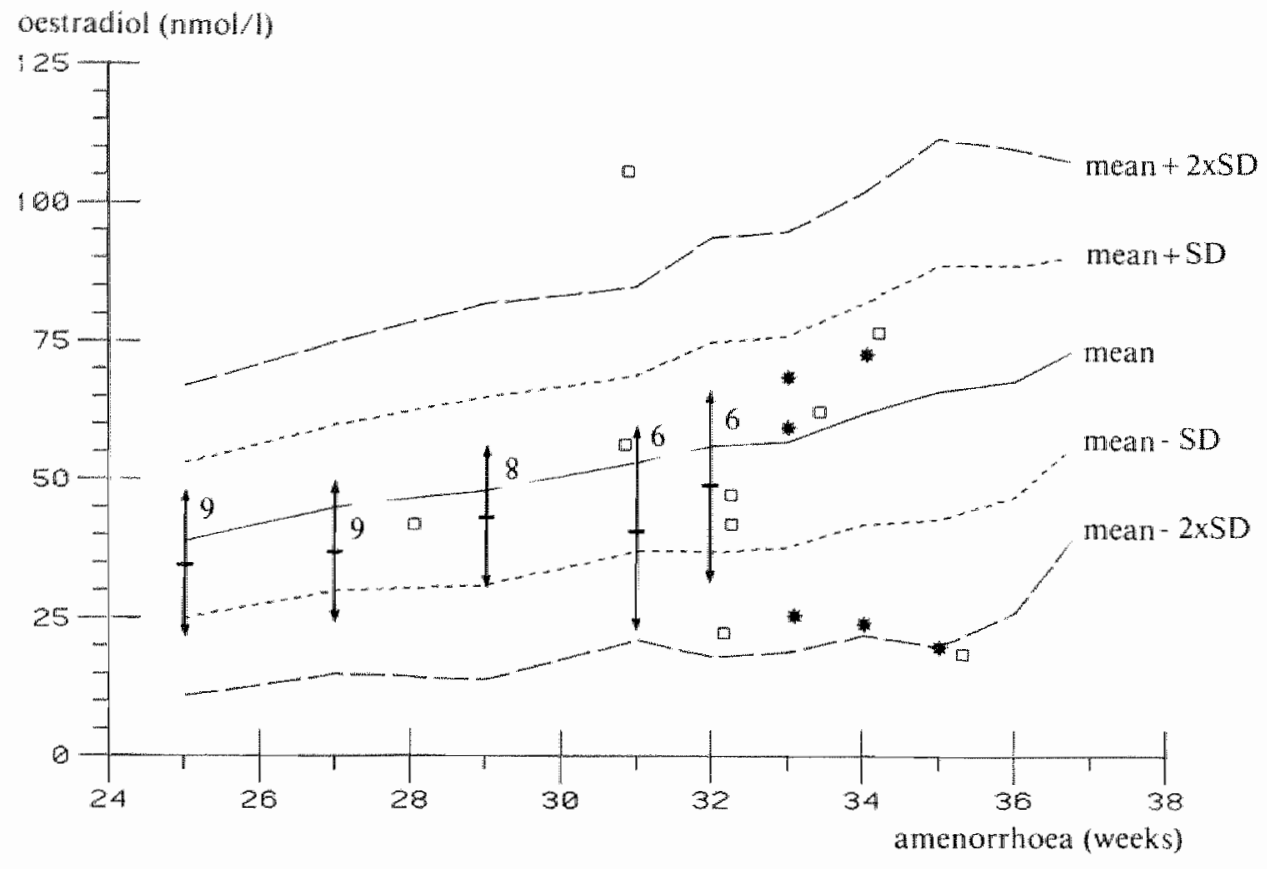

Fig. 4-12: Oestradiol during the preterm period.

PE ratio

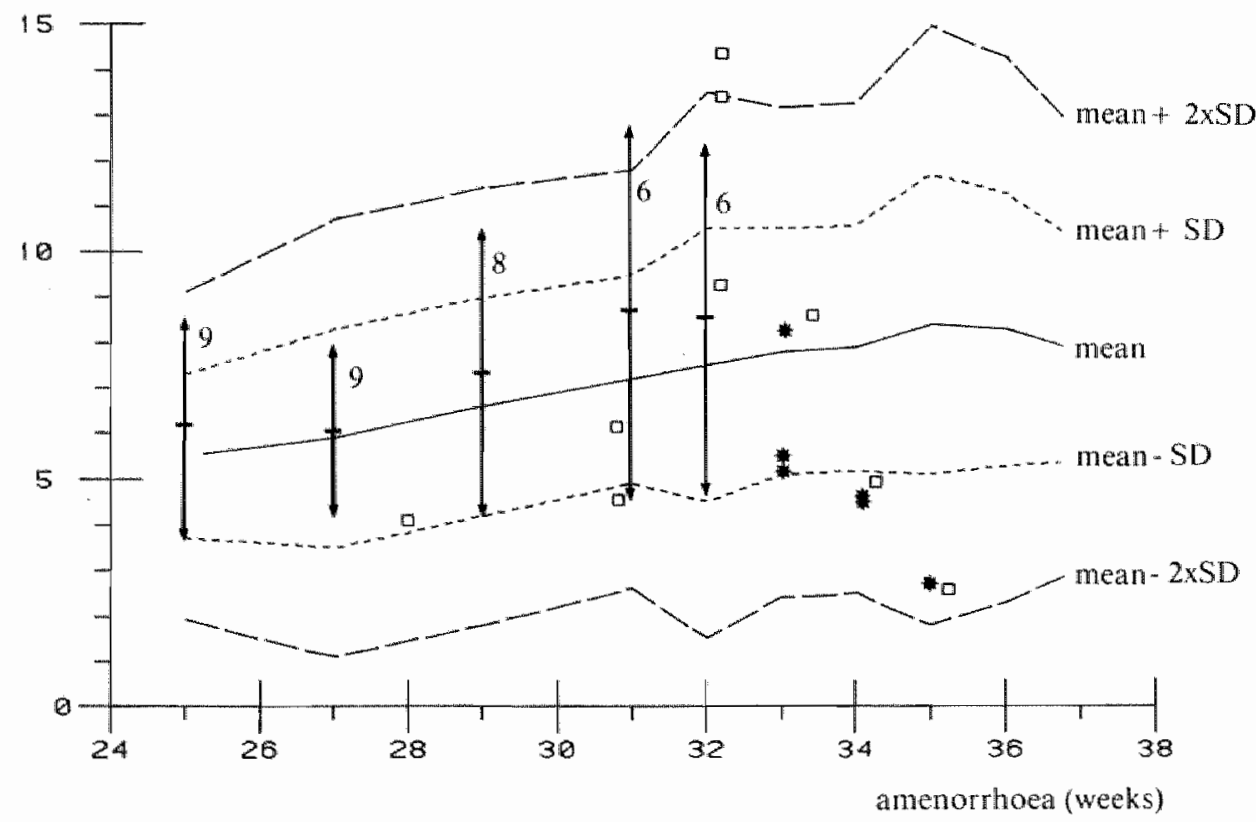

Fig. 4-13: PE, ratio during the preterm period. 


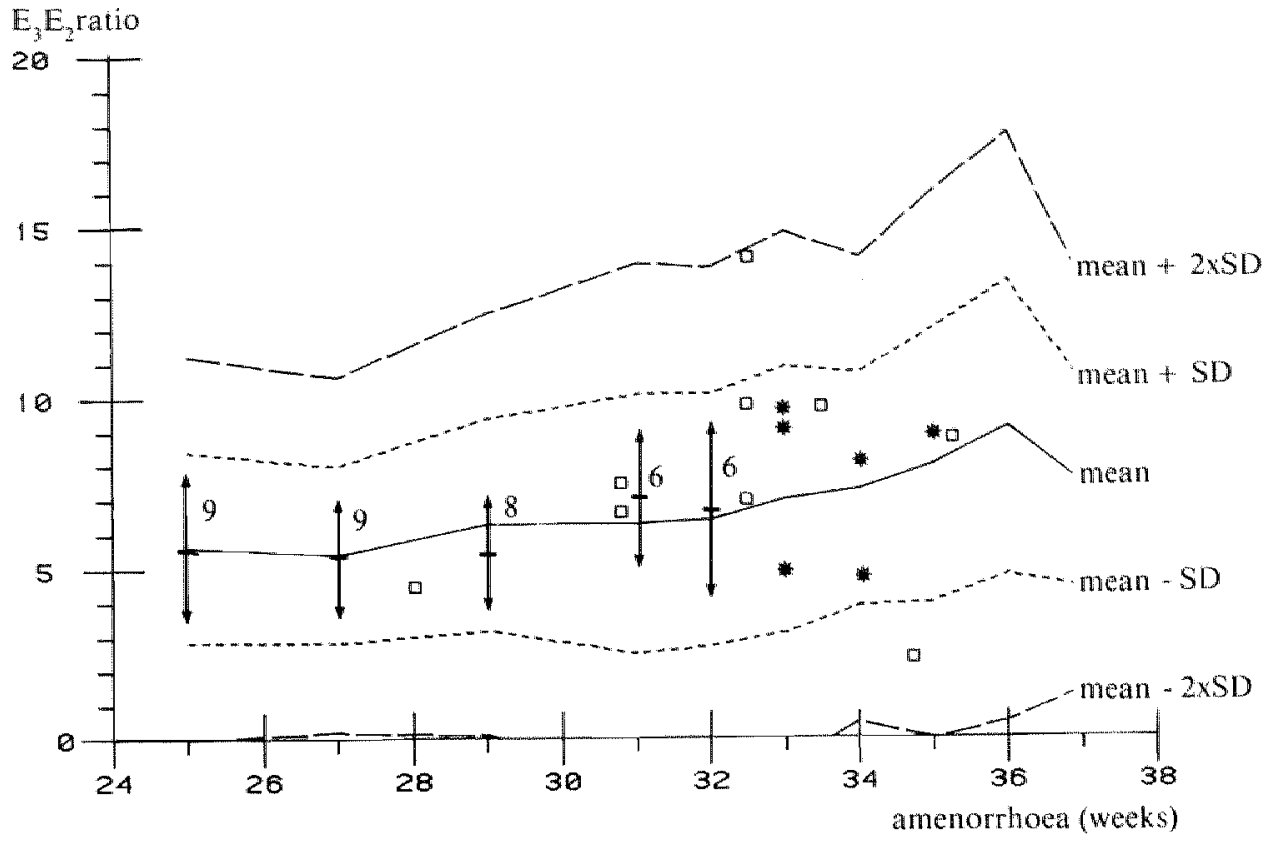

Fig. 4-14: E, E, ratio during the preterm period.

Two aspects of the pathological group can be obserwed; firstly the values (expressed in arrows and asterisks) during the period in which uterine activity did not require any therapy and secondly, the latest values prior to the onset of therapy.

The comparability of the values obtained during the regular visits between the pathological group and the standard group is shown in table IV-1, expressed as the P-value (Kruskal -Wallis test). It has to be stressed that the number of patients in the control group is much smaller than in the standard group.

The results of the hormonal measurements within 12 hours prior to the onsef of treatment show such a wide dispersion that no value of these measurements tor the prediction of preterm labour can be expected.

Table IV-1: Comparison of the hormonal parameters berween the complicated and uncomplicated pregnancies.

\begin{tabular}{lllll}
\hline & Progesterone & Destradiol & $\mathrm{pE}_{2}$ ratio & $\mathrm{E}_{3} \mathrm{E}_{2}$ ratio \\
\hline P-value* 25 weeks amenorrhoea & 0.929 & 0.356 & 0.617 & 0.963 \\
P-value 27 weeks amenorrhoea & 0.168 & 0.079 & 0.971 & 0.975 \\
P-value 29 weeks amenorrhoea & 0.780 & 0.386 & 0.460 & 0.191 \\
P-value 31 weeks amenormoea & 0.604 & 0.225 & 0.433 & 0.415 \\
P-value 32 weeks amenorrhoea & 0.685 & 0.269 & 0.492 & 0.907 \\
P-value 33 weeks amenorrhoea & 0.492 & 0.696 & 0.249 & 0.688 \\
P-value 34 weeks amenorrhoea & 0.107 & 0.372 & 0.177 & 0.858 \\
P-value 35 weeks amenorrhoea & 0.281 & 0.193 & 0.898 & 0.895 \\
\hline
\end{tabular}

* Kruskal-Wallis test. 


\subsection{Discussion}

One of the problems with the management of preterm labour is the fact that there is no distinguishing parameter to predict clearly, early and easily the onset of preterm labour. The early detection of preterm labour is necessary because until now preterm labour can only be diagnosed when it is already established and consequently successful treatment will be difficult (Pritchard and MacDonald, 1976). The alternative is a more agressive attitude featured by an onset of tocolytic treatment early in the process of expected preterm labour. Treatment of numerous patients with false labour will be unavoidable with this approach.

From a theoretical point of view there should be some predictive value in the hormonal status of the pregnant patient and a woman should be able to detect increasing uterine activity. However, from the present study it is clear that this theoretical concept does not lead to a useful clinical applicability.

In the meantime this does not signify that this theoretical concept with regard to the hormonal parameters should be entirely wrong because the measured peripheral plasma levels of the specific hormones are not necessarily well correlated to the hormone levels in the target cells. Up to now the unaccessibility of the target cells for these hormones hinders a further investigation of this parameter to predict preterm labour. The experimental work in this field (Batra et al., 1979; Parlati et al., 1982) may offer possibilities for more insight and clinical applicability in the future. 


\section{Efficacy of orally administered ritodrine after initial intravenous therapy}

\subsection{Introduction}

Although it is generally accepted that intravenously administered ritodrine inhibits uterine contractility and postpones untimely delivery in a proportion of patients with threatening preterm labour, no such agreement exists with respect to its oral administration. There is no general agreement since only a few investigations, with controversial results, have been undertaken to test the efficacy of ritodrine administered in this way. Another reason why there is no consensus of opinion at this point may be the poorly defined fields of indication in the studies done so far.

Oral administration of a drug may cover an enlarged field of indications because of the relative ease of this way of administration. In case of ritodrine in obstetrics this drug is used orally for several reasons, including initial treatment of supposed threatening preterm birth, continuation after initial intravenous treatment, prophylaxis of preterm birth in selected cases and treatment for prevention of foetal growth retardation.

So far no prospective, double blind and allocated study has been published regarding the use of ritodrine as initial treatment for preterm labour. A reason for this could be the expected lower serum levels after oral administration and the concomitant expected lack of success with this kind of treatment.

The prophylactic walue of orally administered ritodrine has been studied in cases of twin pregnancies (O'Connor et al., 1979; Winter and Weiss, 1979; Cctrulo and Freeman, 1976) and in patients who were supposed to be at high risk for preterm labour (Walters and Wood, 1977). None of these studies showed a pregnancy-extending effect of orally administered ritodrine.

If ritodrine is administered orally after initial intravenous treatment one can wonder whether this should be regarded as prophylaxis in high risk cases or as part of the entire treatment.

There are arguments for both points of view. The first opinion starts from the principle that intravenous treatment has resolved the period of threatening preterm labour, the second opinion takes the line that only temporary inhibition of uterinc contractions has been achieved and that these will recur after cessation of intravenous treatment.

Only one study has been published regarding the efficacy of orally administered ritodrine after initial parenteral ritodrine treatment (Creasy et al., 1980 ). The results of this investigation suggest that orat ritodrine maintenance will decrease the incidence of recurrent preterm labour in patients who initially had successful tocolysis. However, the conditions under which Creasy's study has been performed are different from those cncountered in countries where there is more experience with and less fear of beta-mimetic drugs. The initial therapy consisted of intramuscular administration of ritodrine. Although there is at 
fast absorption after this way of application, which rapidly results in maximum serum levels, these ritodrine serum levels are significantly lower compared to the serum levels obtained during intravenous administration of this drug.

A consequence of this regime ma be the inadequate inhibition of uterine activity which resulted in 4 foctal losses ( 7 per cent).

On the other hand, because of the adequate inhibition of uterine activity by means of iritramuscular ritodrine in the resulting patients, this may indicate that this investigation has been carried out in a group of patients with easily inhibitable uterine activity and consequently there could be an indication for oral maintenance therapy for these patients. A second argument in lavour of the ease of inhibition is the short period during which parenteral ritodrine was indicated.

Keirse (to be published) in a similar randomized study as the present one, except for a different scheme of reducing the intravenous dosage and switching to orall therapy, did not find a pregnancy-extending effect of orally administered ritodrine after initial inhibition vitu the intravenous route.

Baumgarten et al. (1982) studied the effect of orally administered beta-mimetic drugs, using an oxytocin stimulated puerperal model. When $20 \mathrm{mg}$ ritodrine was administered orally, in this model an inhibition of only 25 per cent of the original uterine activity was achicved.

In the original work of Wesselius-de Casparis et al. (1971) it is not defined whether the benefit of the treatment is a result of the intravenous or the oral part of the schedule. Based on these data from the literature and clinical impressions with orally administered beta-mimetic drugs there appeared to be a need to investigate the effect of oral ritodrine in a randomized trial and to answer the question whether or not it is necessary to substitute oral ritodrine for intravenous ritodrine after inhibition of preterm labour has been achieved by intravenous administration of ritodrine.

It was the purpose of this study to examine

- the neod for further oral drug treatment after threatening preterm labour had been arrested with intravenous ritodrine.

the efficacy of oral ritodrine maintenance therapy in lengthening the duration of pregnancy and/or in avoiding relapses (requiring a second episode of intravenous therapy) after affirt episode of threatening preterm labour was overcome by intravenous administration of ritodrine.

\section{2. $\quad$ Materials and methods}

The study was performed at the Department of Obstetrics and Gynaecology of the Sint Annadal Hospital, State University Limburg Maastricht between February, 1980 and May, 1982. During this time 442 patients were admitted during the preterm period of their pregnancy with threatening labour (348 patients), ruptured membranes without uterine activity (39 patients) and or conditions (maternal/foetal) which required induced preterm Uabour ( 55 patients).

From the 348 patients with intact foetal membranes and threatening preterm labour it was thought that 223 paticnts needed tocolytic treatment. Reasons for abandoning tocolytic 
therapy was spontameous cessation of uterine activity after observation only ( 59 patients). too far adwanced dilation of the cervix ( 56 patients) and in 10 patients there were contraindications against the use of beta-mimetic drugs.

During the tocolytic treatment in 106 patients discontinuation of i.y. thorapy was indicated because of progress of Aabour ( 51 patients) or the appearence of contra-indications to continue tocolytic treatment (55 patients).

Patients included in this trial were selected from the remaining 1.17 patients.

The following criteria were used:

- no medical and/or obstetrical contra-indications for the continuation of ritodrine treatment (table $\mathrm{V}-1$ ),

- intact foetal membranes,

- cervix dilated 3 cm or less,

- certainty of gestational age ${ }^{*}$.

- duration of pregnancy between 24 and 36 weeks at the start of intravenous treatment.

- threatening preterm labour which was successfully inhibited with intravenous ritodrine*

- absence of uterine contractions for at least 24 hours which permitred the cessation of intravenous therapy and the start of oral medication ${ }^{*}: *$ :

* Certainty of gestational age was based on a history of regular menstrual periods and a cortain first day of the last mormal menstrual

period and/or based on sonographical measurements in early pregnancy.

* The diagnosis of preterm labour was made at a gestational age of less tham 37 weeks, if uterne: contractions occurred at least every 10 minutes, lasted each at least 30 seconds and werc prescont for at least 2 hours. The presence of contractions and their frequency were documented by extornat tocodynanometry (Corometrics foetal Monitor. 112). If no contra-indications were present in the obstetrical history. a single pelvic examination was performed to determine the dilation and chacenent of the cervix.

The initial treatment consisfed of bedrest and tocolysis by means of intravenously adnwinstered

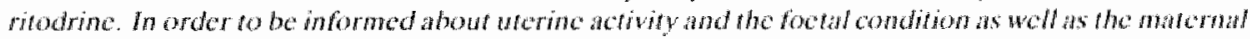
condition, contimuous cardiotocography and materwa blood pressure and heart frequency recondings

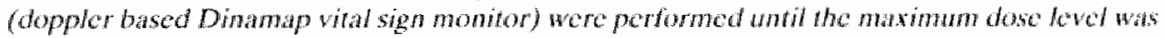
achieved in principle a maternal clectrocardiogram was obtaned withen 24 hours after the owiset of treaturent.

Ritodrine was administered by a infusion pump with a 170 wate of 0.0109 .9 mblhou (Vickers Me dical Troonic digial syringe pump).

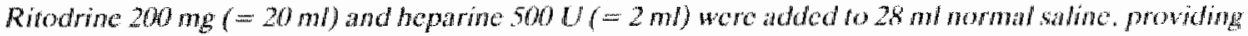
a concentrationof $4 \mathrm{mg} / \mathrm{m} /$.

The infusion started ar at rate of $100 \mathrm{mcg} / \mathrm{min}$ and was increased by $3.3 \mathrm{mcg} / \mathrm{min}$ at every $15 \mathrm{minutes}$ interval, until contractions stopped or unacceptable side effocts developed. Once whe tevel of

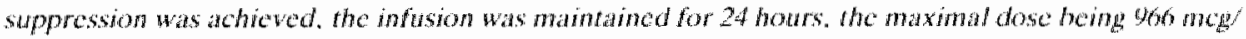
mins.

The intusion rate was then decroased by 33 - 50 meg/min every 12 hours as long as contractility did not reappear whil the infusion tate of $200 \mathrm{mcg} / \mathrm{min}$ was acheved.

* * Inhibition of atcrime contractions, which perminted to finsh intravenows therapy and to swith to oral medication was defined as less than 3 contractions per hour, verified by external tocodynamometry and les than 15 contractions per 24 hours. experienced by the paticn. The infusion rate had to bo lcss than or equal to $200 \mathrm{mcg} / \mathrm{min}$ at that particular momem.

After a period of 24 hours of inhibition of werine contractions als defined above, the wntravenous ritodrine dosage was reduced and switched to oral treatment as shown in fig. $5-1$. 
Finally ninety-six conscutive patients, fulfiling the above criteria and therefore eligible for mantenance therapy, made up the original population for this investigation.

Table V-1: Medicat and obsterrical contra-indications (absolute and relative) agrainst the use of bea-mimetic drugs.

hyperthyroidism heart disease dystrophia myotonia pheochromocyloma infections - fever coagulation disorders shock use of conticosteroids pregnancy induced hypertension

abruptio placenta

vaginall bleeding from unknown cause

foetal anomaly incompatible with life

dead foetus

foetal distress

ruptured membrames

1.v. dogeritodrine (nog/min)

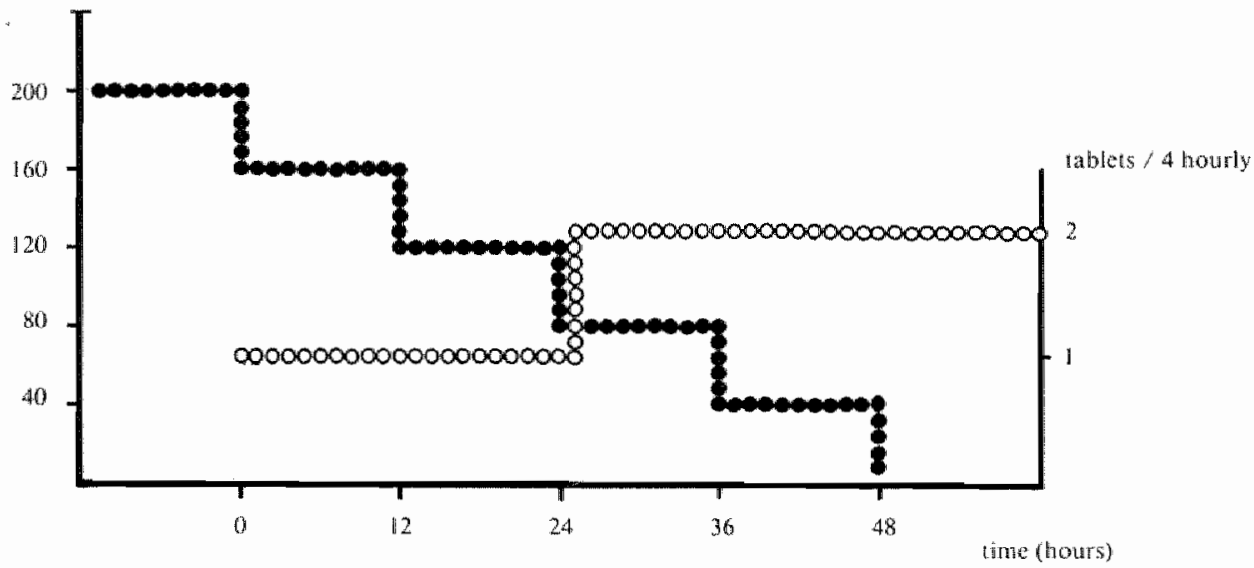

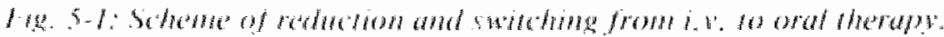

The patients received cither $10 \mathrm{mg}$ ritodrine or identical-appearing placebo tablets, according to a doublo blind allocated method. The code was not broken until the treatment of all patients had been completed.

The intravenous infusion rate was reduced by $1 / 5$ th of the original dosage every 12 hours (total cluration: 48 hours). Oral medication was started from the beginning of the reduction of the intravenous dose: the first 24 hours one tablet every 4 hours, the second 24 hours two tablets foum-hourly.

The oral medication was continued until

- the 259 th day of prognancy was achicvod

- reintusion was necessary

- Foctal andior maternal pathology developed, which contra-indicated continuation of the preatment.

The necessity of reinfusion was based on the same undications as for theinitial treatment (page 49). The contra-indications for continuation of the therapy were the same as listed in table $\mathrm{V}=1$. 
In order to be informed about the comparability between the patients who recenved ritodrine tablets (the R-group) and the patients who were administered placebo tablets (the P-group), statistical analyses were performed on the characteristics of these two groups before the onset of intravenous and the onset of oral treatment.

If no specification of the method used is given, then the statistical test used was the ManuWhitney-U Test (Wilcoxon-Test).

With regard to a possible pregnancy-extending effect of orally administered ritodrine, onesided statistical testing was performed, and a Pualue of 0.05 was chosen as the limit of significance.

\subsection{Results}

\section{Comparability between the ritodrine and the placebo group at the onset of intravenous treatment.}

Ninety-six patients initially fulfilled the criteria to enter the study. In 7 cases it was necessary to withdraw the medication during the oral course of treatment. The results of these 7 patients have not been included in the final considerations becaluse the aim of the study was to investigate the pregnancy extending effect of orally administered ritodrine and because of that intervention fulfilment of this aim of the study could not be evaluated. The reasons for the discontinuation of the treatment in these patients are listed in table V-2.

Table W-2: Reasons for discontinuation of oral ritodrine treament apart from recurende of werine activity or achieving day 259 of pregnancy.

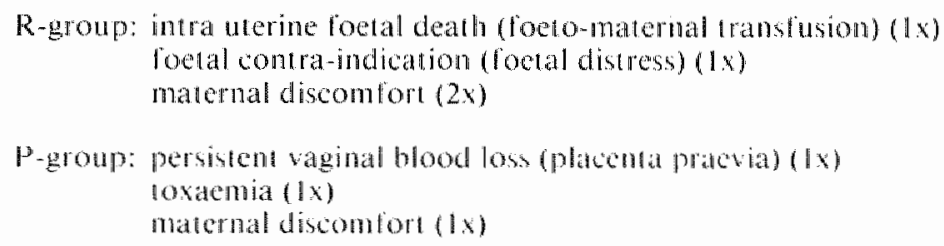

Among the remaining 89 patients there were 5 patients with a win pregnancy: 3 in the $R$ group and 2 in the P-group.

So finally the groups consisted of 44 patients in the R-group and 45 in the P-group.

The obstetrical history of the patients (table $V_{-3}$ ) and other characteristics (able V-4) were similat for the rilodrine-and the placebo-group. 
Table V-3: Reproductive history of the patients studies.

\begin{tabular}{lrrrrrrrr}
\hline & \multicolumn{2}{c}{ parity } & \multicolumn{2}{c}{$\begin{array}{c}\text { spontaneous } \\
\text { abortion }\end{array}$} & $\begin{array}{c}\text { induced } \\
\text { abortion }\end{array}$ & \multicolumn{2}{c}{$\begin{array}{c}\text { preterm } \\
\text { birth }\end{array}$} \\
\hline Number & Rit. & Plac. & Rit. & Plac. & Rit. & Plac. & Rit. & Plac. \\
\hline 0 & 23 & 20 & 34 & 41 & 41 & 45 & 38 & 39 \\
1 & 18 & 16 & 9 & 4 & 3 & & 6 & 5 \\
2 & 3 & 5 & 1 & & & & & 1 \\
3 & & 3 & & & & & & \\
4 & 1 & & & & & & & \\
\hline
\end{tabular}

Table Vu4: Characteristics of the stadied patients at the onset of therapy.

\begin{tabular}{|c|c|c|c|c|}
\hline & \multicolumn{2}{|c|}{ Ritodrine $(N=44)$} & \multicolumn{2}{|c|}{ Placebo $(N=45)$} \\
\hline & Mean $\pm S D$ & Range & Mean $\#$ SD & Range \\
\hline $\begin{array}{l}\text { Maternal age } \\
\text { (in years) }\end{array}$ & $26 \pm 4$ & $16-37$ & $26 \pm 4$ & $17-34$ \\
\hline $\begin{array}{c}\text { Maternal weight } \\
\qquad \text { (in } \mathrm{kg} \text { ) }\end{array}$ & $67 \pm 16$ & $49-144$ & $67 \pm 9$ & $5 \rrbracket-89$ \\
\hline $\begin{array}{c}\text { Maternal height } \\
\text { (in cmy) }\end{array}$ & $162 \pm 6$ & $149-177$ & $163 \pm 6$ & $15 \|-178$ \\
\hline $\begin{array}{c}\text { Systolic blood pressure } \\
\text { (in mon } \mathrm{Hg} \text { ) }\end{array}$ & $121 \pm 14$ & $90-180$ & $121 \pm 12$ & $100-160$ \\
\hline $\begin{array}{c}\text { Diastolic blood pressure } \\
\text { (in mm } \mathrm{Hg} \text { ) }\end{array}$ & $71 \pm 10$ & $50-90$ & $72 \pm 13$ & $50-110$ \\
\hline $\begin{array}{r}\text { Matermal hearliate } \\
\text { (beals/min) }\end{array}$ & $83 \pm 12$ & $60-116$ & $87 \pm 12$ & $64-120$ \\
\hline Haemoglobin & $7.0+0.6$ & $5.7-7.8$ & $7.1 \pm 0.6$ & $5.6-8.7$ \\
\hline
\end{tabular}

Because of the exclusion criteria, described in table $V$ - 1 , there were no important differences in the past medical history between the two groups.

In the rilodrine group there was one patient with uterine fibroids and one patient with diabetes mellitus, class $C$ according to White (1978), as well as one patient with pregnancyinduced diabetes mellitus.

The comparability between the $\mathrm{R}$ - and the $\mathrm{P}$-group regarding the present pregnancy is shown in table $V=5$. 
Table V-5: Comparabilty between the R-and P-growp of characteristics regarding the present pregrancy.

\begin{tabular}{|c|c|c|c|c|c|c|c|}
\hline & \multicolumn{3}{|c|}{ Rnodrine } & \multicolumn{4}{|c|}{ Placebo } \\
\hline & Mean $\pm S D$ & Range & $N$ & Meant $5 D$ & Range & $N$ & Pualue \\
\hline $\begin{array}{l}\text { Amenorrhoea (in days) a } \\
\text { onset of uterine activily }\end{array}$ & $217 \pm 24$ & $152-250$ & 44 & $214-26$ & 147.250 & 45 & 0.480 \\
\hline $\begin{array}{l}\text { Amenorhoea (in days) at } \\
\text { onset of i.v. Ireatment }\end{array}$ & $218 \pm 24$ & $152-250$ & 44 & $215 \pm 26$ & $157-250$ & 45 & 0.473 \\
\hline $\begin{array}{l}\text { Contractions (per hour) at } \\
\text { onset of i. w. treathent }\end{array}$ & $14 \pm 5$ & $6-30$ & 44 & $15 \pm 5$ & $6-30$ & 45 & 0.121 \\
\hline $\begin{array}{l}\text { Tocolytic index at } \\
\text { onset i.v.treatment }\end{array}$ & $2.7 \pm 0.7$ & $1-4$ & 40 & $2.9 \pm 1.6$ & $1-5$ & 39 & 0.502 \\
\hline
\end{tabular}

The tocolytic index according to Baumgarten and Gruber (1974) is used to describe the possibility and ease of inhibition of uterine contractility (table $\mathrm{V}-6$ ). The authors only give a random citcumscription of uterine activity. To define irregular and regular contractions in the present study, from 5 up to 10 contractions per hour were honoured with one point: more than 10 contractions per hour with two points. These limits were based on the study of Zahn (1978) using the 97th centile as the upper limit of physiological uterine activity.

Table V 6: Tocolynic Index (Banmgarien and Gruber, 1974).

\begin{tabular}{|c|c|c|c|c|}
\hline & 1 & 2 & 3 & 4 \\
\hline Contractions & irregular & regular & - & - \\
\hline Rupt. membranes & - & high & $\cdots$ & low \\
\hline Bleeding & spotting & bleeding & -. & -- \\
\hline Dilatation & $1 \mathrm{~cm}$ & $2 \mathrm{~cm}$ & $3 \mathrm{~cm}$ & $4 \mathrm{~cm}$ \\
\hline
\end{tabular}

The duration of amenorrhoea at the onset of uterine contractions was considered as from the time of admission to hospital. The delay between the onset of treatment and onset of uterine contractillty is explained by the conservative attitude in case of initially dubitable uterine contractility, which then increased with time.

No differences were found between the $R$ - and the $P$-group regarding characteristics of the preserut pregnancy.

\section{Comparability between the ritodrine and the placebo group during the intravenous treatment and at the onset of oral treatment}

The duration of intravenous treatment is defined as the period during which ritodrine was administered by the intravenous route only. The duration and the level of the infusion did not differ significantly in both groups (table V-7, fig. 5-2). 
Table V-7: Comparability between the $R$ - and P-growp with regard wo the duranion of infovencus treatment, maximal dosage and the onse? of ord therapy.

\begin{tabular}{|c|c|c|c|c|c|}
\hline & \multicolumn{2}{|c|}{ Ritodrine $(n=44)$} & \multicolumn{3}{|c|}{ Placebo $(n=45)$} \\
\hline & Mean $\pm \$ D$ & Range & Mean $\pm \mathrm{SD}$ & Range & P-value \\
\hline Duration (in days) of iv e reatmen & $8 \pm 6$ & 1.29 & $9 \pm 7$ & $1-35$ & 0.798 \\
\hline Max. dosage (in mcg/min) & $233 \pm 145$ & $100-433$ & $254 \pm 151$ & $66-966$ & 0.204 \\
\hline $\begin{array}{l}\text { Amernorthoed at the onset (in days) } \\
\text { of oral treatment }\end{array}$ & $225 \pm 23$ & $159-252$ & $224 \pm 22$ & 167.252 & 0.428 \\
\hline
\end{tabular}

The duration of amenorrhoea at the onset of oral treatment is defined as the amenorrhoea in days at the time of starting oral treatment; this implies that the patient still received a considerable, yet decreasing, amount of ritodrine by the intravenous route during the first 48 hours. The comparability between the 2 groups of the start of oral therapy is expressed in figure $5-3$.

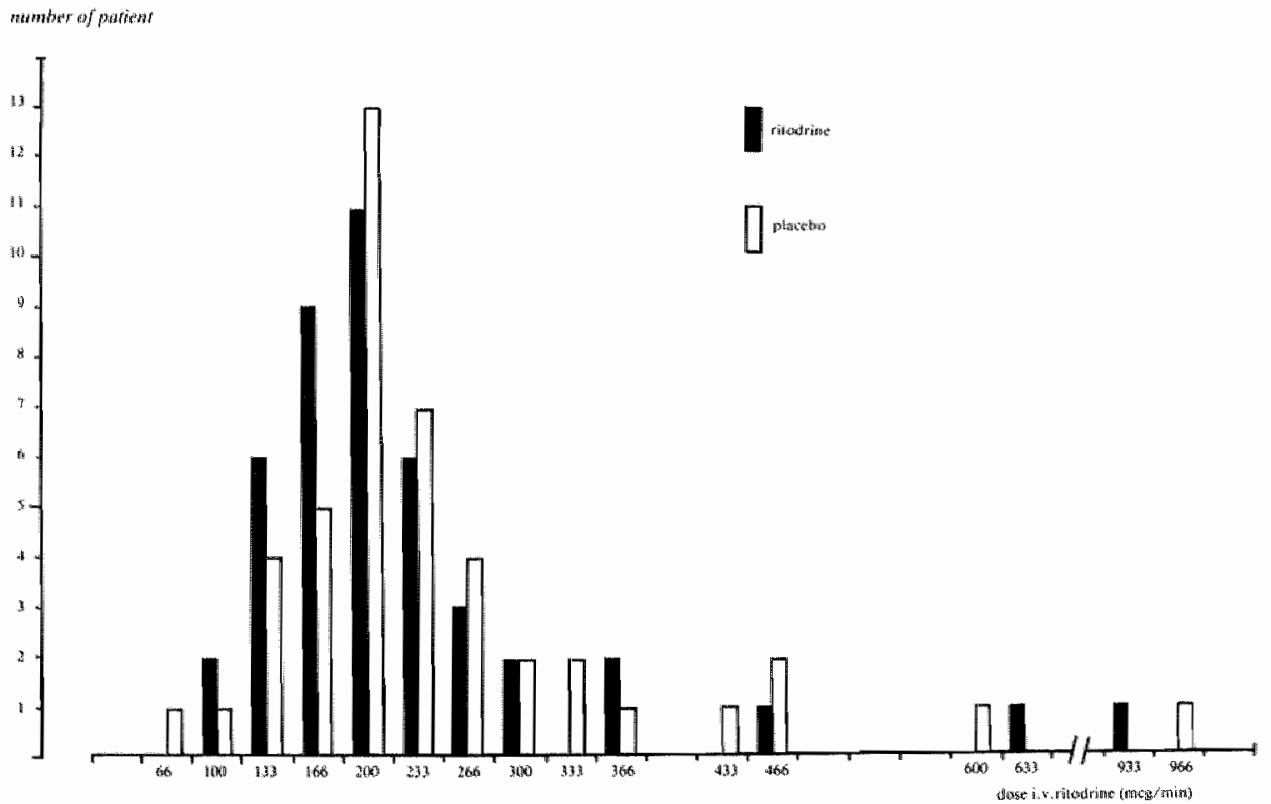

Fig. 5.2 Initial dose of intravenous ritodrine 


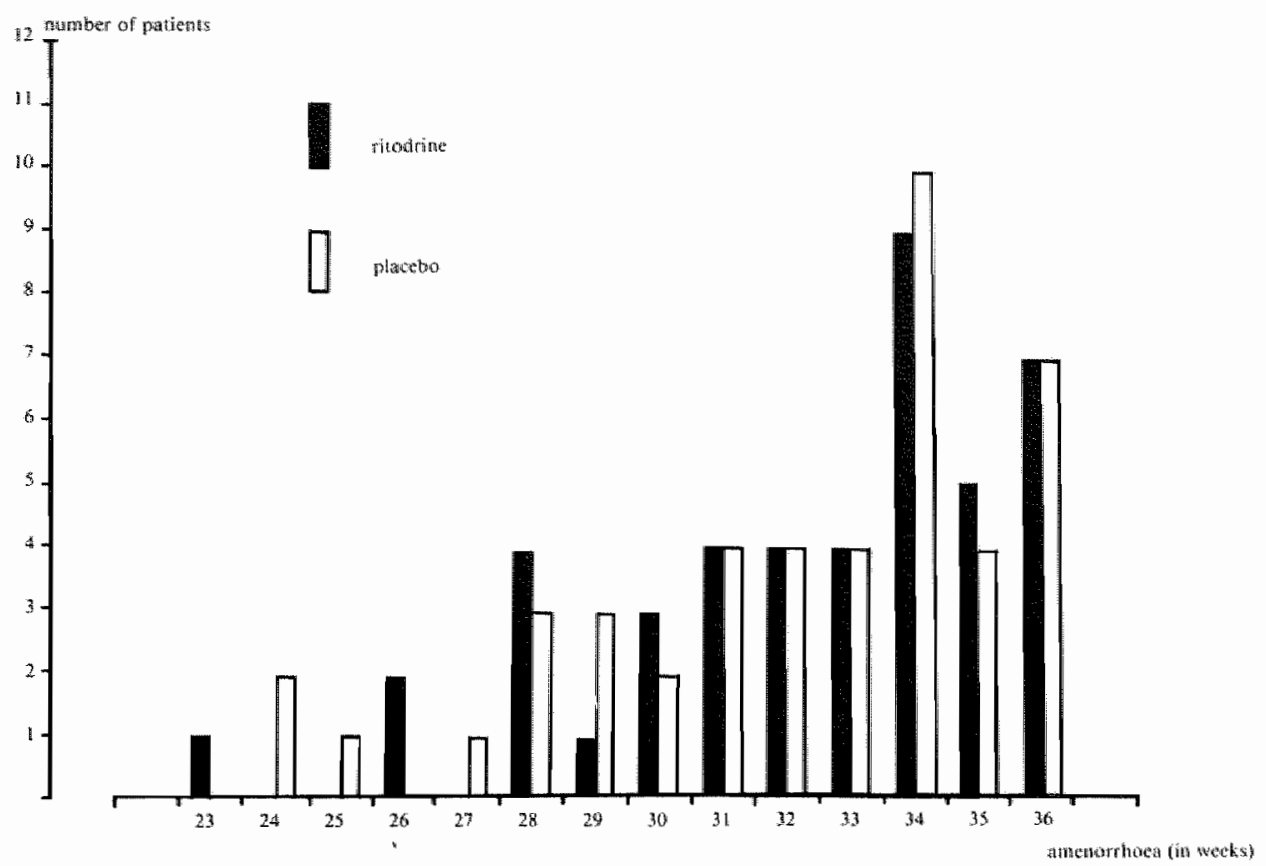

Fig. 5-3 Comparability between the $R$-group and P-group regarding the amenorthoea at the onset of oral therapy

The mean maternal blood pressure did not change significantly during the intravenous treatment when compared to the blood pressure before the onset of treatment, nor were there differences between the studied groups.

No differences, either, were found in the maternal heart rate between the $\mathrm{R}$ - and P-group. There was an (expected) increase of the maternal heart rate when compared to the pretreatment maternal heart rate (Fig. 5-4).

\section{Judgment of success}

Success of a tocolytic treatment can be judged in different ways. One has to judge the foetal outcome and the pregnancy-extending effect. The latter can be done, again, in different ways and each of these has its own limitations and pitfalls. In this study a possible pregnancy-extending effect of orally administered ritodrine has been evaluated in 4 manners:

- comparison of the duration of oral treatment between the two groups

- comparison of the duration of amenorrhoea at delivery between the two groups

- comparison of the prolongation index* between the two groups

- comparison of the relative gain* between the two groups 


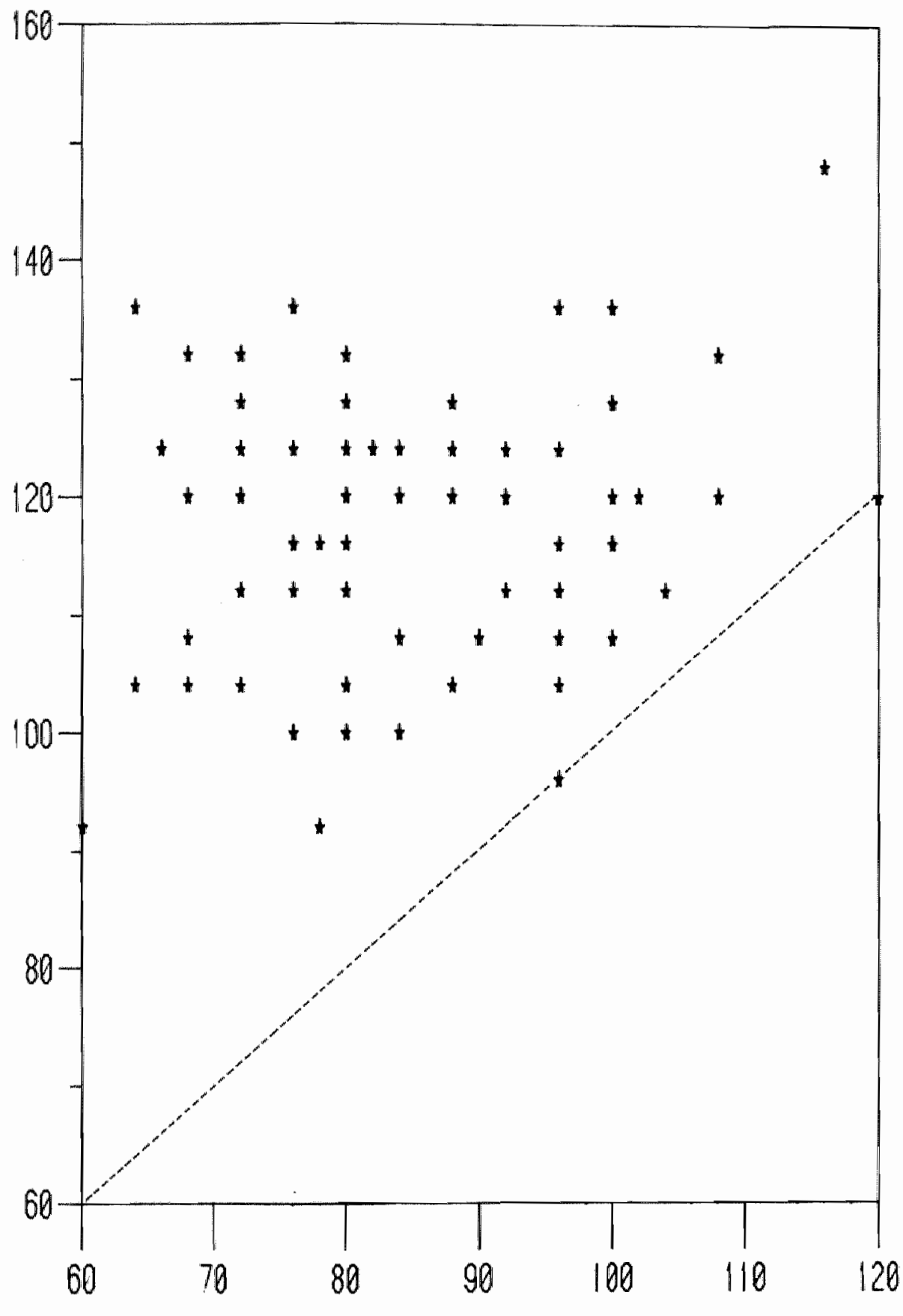

mat. heart rate before treatment (beats/min)

Fig. 5-4 Relation beween maternal heart rate before and during intravenous treatment with ritodrine 
* The prolongation index (PI) according to Richter (1977) and the relative gain are defined as:

$P I=\frac{\Delta t}{t_{0}} \times 100$

Rel.gain $=\frac{D_{e}-D_{0}}{259-D_{o}} \times 100$

$\Delta t=$ lag time between onset of therapy and delivery (expressed in weeks)

$t_{0}=$ gestational age at the onset of therapy (expressed in weeks)

$\mathrm{D}_{\mathrm{e}}=$ gestational age at the end of oral treatment (expressed in days)

$D_{0}=$ gestational age at the onset of treatment (expressed in days).

\section{Comparison of the duration of oral treatment between the fwo groups.}

There were three reasons for discontinuation of oral ritodrine therapy; the initial aim (achieving the 259 th day of pregnancy) was attained, uterine activity recurred or side effects developed which formed a contra-indication for the continuation of therapy. The latter group is discarded from the statistical analysis.

Generally in the case of recurrence of uterine activity as defined on page 48 reinfusion was started but in 8 patients progress of dilatation and/or rupture of the membranes contra-indicated recommencement of intravenous application of ritodrine. These patients were considered to be "non-inhibitionable".

A sub-division was made between the patients who needed reinfusion after the procedure of reducing and switching from intravenous to oral therapy was completed (reinfusion after 2 days) and those patients in whom uterine activity recurred during this process (reinfusion within 2 days).

The reasons for discontinuation of oral therapy are shown in table $V-8$ and the duration of oral treatment in fig. 5-5. The table shows definitive trends towards improvement for the R-group. However, this result does not show significant differences at the 0.05 level (Chisquare test $)(p=0.10)$.

Table V.8 Reasons for discontinuation of oral therapy of the patients studied.

\begin{tabular}{|c|c|c|c|c|c|c|}
\hline & \multicolumn{2}{|c|}{ All patients } & \multicolumn{2}{|c|}{ Group $A$} & \multicolumn{2}{|c|}{ Group $B^{*}$} \\
\hline & Rit & Plac & Ril & Plac & Rit & Plat \\
\hline achieving day 259 or pregnancy & 23 & 15 & 19 & 13 & 4 & 2 \\
\hline reintusion alter 2 days & 9 & 10 & 9 & 8 & - & 2 \\
\hline reinfusion within 2 days & 9 & 15 & 7 & 13 & 2 & 2 \\
\hline \multirow[t]{2}{*}{ non-inhibitionable } & 3 & 5 & 2 & 4 & 1 & 1 \\
\hline & 44 & 45 & 37 & 38 & 7 & 7 \\
\hline
\end{tabular}

* Group A comprises the patients whose oral treatment commenced belore the end of the 35 th week of pregnancy.

Group B comprises the patients whose oral treatment started after the 35 th week of pregnancy. 

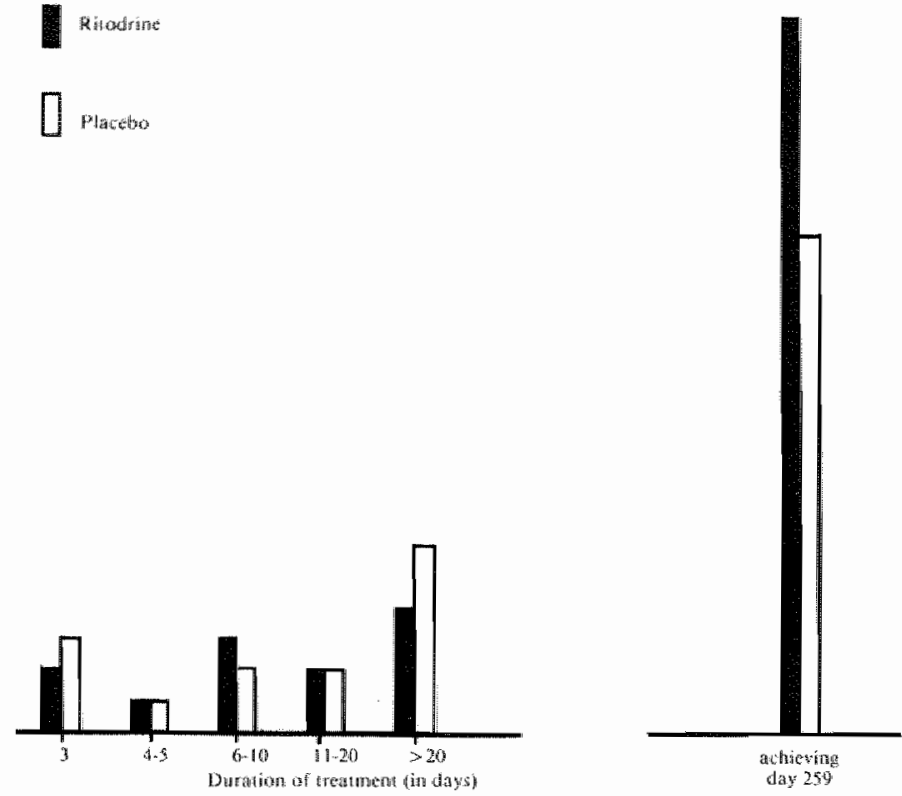

treatment (pathents achieving day 259 of pregnancy: right colom).

nts who needed reinfusion yielded interesting results. Nineteen urely despite (sometimes) high doses of intravenously patients delivered within 5 days after cessation of treatment and is or more after cessation of tocolytic therapy. ween the initial intravenous doses of ritodrine and the reinfusion nificantly higher than the initial dose (paired Student-t lest:

ration of oral treatment between the 2 groups is shown in tablle Is to a large extent on the time of onset of oral treatment, for a terapy in the 36 th week of pregnancy only needs one week of znt, starting in the 27 th week, can gain 10 weeks. So a division is $s$ who started the oral treatment before the end of the 35 th week whereas group B started the therapy after the 35 th week of vas based on the supposition that it is questionable whether after ek of pregnancy tocolysis is indicated at all. 


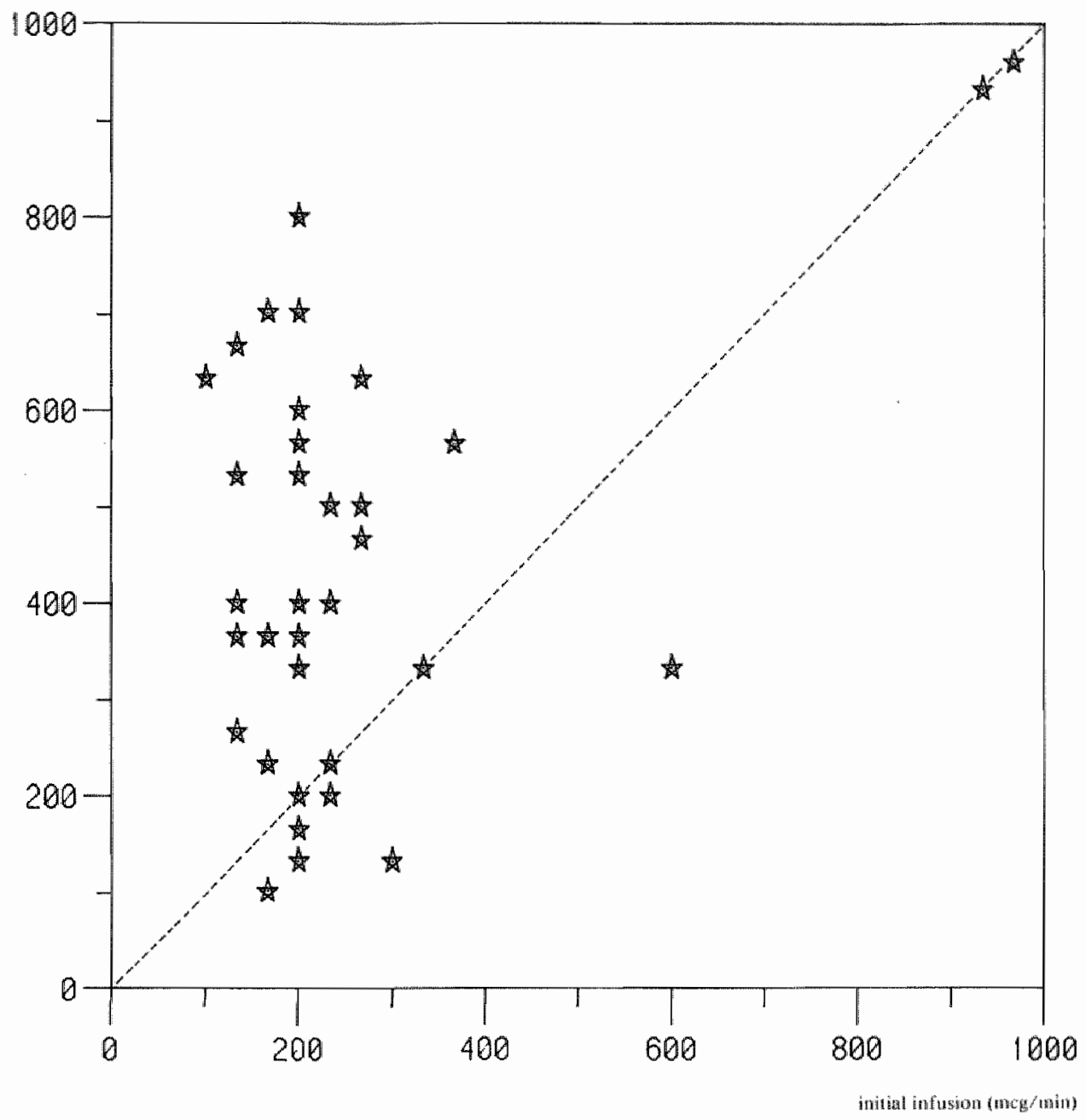

Fig. 5-6 Relation between the rirodrine dosage of reinfusion and intial infusion.

Comparison of the duration of amenorrhoea at delivery between the two groups.

Using the duration of amenorrhoea at delivery as a criterion for the estimation of the effect of long-term betamimetic drug administration may be hazardous. For example, postterm patients could easily be the cause of incorrect conchusions concerning the success of treatment. Another, more important, reason why comparing the duration of amenorrhoes at delivery gives no information on the efficacy of the therapy in this study, is the influence of reinfusion, after uterine activity recurred. Reinfusion masks the initial results of the oral therapy.

However, restarting the intravenous administration of ritodrine was the tool to guatrantec an ethically justified investigation and by comparing the amenorrhoea at the moment of delivery it becomes evident to what extent this condition has been achicved. 
Table Va: Comparison of the duration of orat treatment (in days) between the two graups.

\begin{tabular}{lccc|cccc}
\hline & \multicolumn{3}{c}{ Ritodrine } & \multicolumn{4}{c}{ Placebo } \\
\hline & Mean \pm SD & Range & $N$ & Mean \pm SD & Range & N & P-value* \\
\hline All Patients & $22 \pm 23$ & $0-98$ & 44 & $17 \pm 19$ & $0-64$ & 45 & 0.146 \\
iwin pregnancies excluded & $22 \pm 23$ & $0-98$ & 41 & $17 \pm 18$ & $0-64$ & 43 & 0.084 \\
Group A & $24 \pm 24$ & $0-98$ & 37 & $20 \pm 20$ & 0.64 & 38 & 0.186 \\
twin pregnancies excluded & $26 \pm 24$ & $0-98$ & 34 & $19 \pm 20$ & 0.64 & 36 & 0.101 \\
Group B & $7 \pm 5$ & $1-13$ & 7 & $4 \pm 4$ & $0-10$ & 7 & 0.194 \\
\hline
\end{tabular}

Group A: Onset of oral therapy before the end of the 35 th week of pregnancy.

Group B: Onset of oral therapy after the 35 th week of pregnancy.

* One sided Mann-Whitney U test (Wilcoxon).

When the duration of amenor rhoea at the point of time of delivery is compared between the ritodrine and the placebo group, there is no need for a division in groups based on the amenorrhoea at the onset of oral therapy, as has been performed to compare the total duration of orat treatment. However, for analysis of other parameters, like relative gain, it is important to kmow how the results are related to the onset of treatment. The duration of amenor rhoea at delivery (expressed in days) is shown in table V-10.

Table V.10: Duration of amenorrhoea at delivery (in days).

\begin{tabular}{lcc|ccccc}
\cline { 5 - 7 } & & \multicolumn{4}{c}{ Ritodrine } & \multicolumn{4}{c}{ Placebo } \\
\hline & Mean $\pm \mathrm{SD}$ & Range & $\mathrm{N}$ & Mean $\pm \mathrm{SD}$ & Range & $\mathrm{N}$ & P-value* \\
\hline All Patients & $265 \pm 14$ & $209-297$ & 44 & $265 \pm 14$ & $236-287$ & 45 & 0.779 \\
w win pregnancies excluded & $266 \pm 14$ & $209-297$ & 41 & $266 \pm 14$ & $236-287$ & 43 & 0.693 \\
Group A & $265 \pm 14$ & $209-292$ & 37 & $265 \pm 15$ & $236-286$ & 38 & 0.671 \\
Iwin pregnancies excluded & $265 \pm 14$ & $209-292$ & 34 & $265 \pm 14$ & $236-286$ & 36 & 0.286 \\
Group B & $269 \pm 14$ & $253-297$ & 7 & $266 \pm 13$ & $253-287$ & 7 & 0.796
\end{tabular}

Group A: Onset of oral therapy before the end of the 35 th week of pregnancy.

Group B: Onset of oral therapy afier the 35th week of pregnancy.

Comparison of the prolongation index between the two groups.

Success of tocolysis could be related to the number of days during which pregnancy is prolonged after the onset of administration of a tocolytic agent.

However, it is clear that the earlier in pregnancy tocolysis is started, the more days can potentially be gained. When the duration of amenorrhoea at delivery is used to evaluate the success of a therapeutic regimen the duration of amenorrhoea at the onset of treatment 
is not taken into account.

In an attempt to circumvent this problem Richter (1977) introduced a so-called prolongation index which is calculated by taking 100 times the value of the time interval between the onset of the treatment and delivery, divided by the gestational age on the day of admission.

In table V-11 the prolongation index (P.I.) of this study is shown.

In case of recurrence of uterine activity, resulting in reinfusion of intravenously administered ritodrine, not the time interval between onset of treatment and delivery but the duration of orall therapy was used to calculate the prolongation index.

Table V-11: Prolongation Index

\begin{tabular}{lccc|cccc}
\hline & \multicolumn{3}{c|}{ Ritodrine } & \multicolumn{4}{c}{ Placebo } \\
\hline & Mean \pm SD & Range & $N$ & Mean \pm SD & Range & $N$ & P-value* \\
\hline All Patients & $13 \pm 14$ & $0-62$ & 44 & $11 \pm 14$ & $0-38$ & 45 & 0.194 \\
twin pregnancies excluded & $13 \pm 14$ & $0-62$ & 41 & $11 \pm 12$ & $0-38$ & 45 & 0.174 \\
Group A & $14 \pm 14$ & $0-62$ & 37 & $12 \pm 12$ & $0-38$ & 38 & 0.261 \\
twin pregnancies excluded & $15 \pm 14$ & $0-62$ & 34 & $12 \pm 12$ & $0-38$ & 36 & 0.149 \\
Group B & $6 \pm 7$ & $0-21$ & 7 & $3 \pm 4$ & $0-12$ & 7 & 0.351 \\
\hline
\end{tabular}

Group A: Onset of oral therapy before the end of the 35 th week of pregnancy.

Group B: Onset of oral therapy after the $35 \mathrm{th}$ week of pregnancy.

\section{Comparison of the relative gain between the two groups}

The aim of this study was to investigate whether orally administered ritodrine, after initial intravemous application of this drug in case of threatening preterm labour, could postpone delivery until the preterm period has been passed.

The estimation of success by comparing the amenorrhoea at delivery or measurement of the total days of treatment is strongly influenced by the amenorrhoea at the onset of treatment.

On the other hand, the prolongation index is influenced in a positive way by longer duration of pregnancy (for example post maturity) which was not the initial aim of the treatment. The strong influence of the amenorrhoea at delivery on the P.I. is shown in the following example:

$\begin{array}{ll}\text { Pt. I } & \text { Pt. II } \\ 3 J \text { wks } & 31 \text { wks } \\ 37 \text { wks } & 43 \text { wks } \\ 19 & 39\end{array}$

Note that there is $100 \%$ increase of P.I. when the patient does not deliver at the 37 th week but becomes postterm.

It was thought that the relative gain as formulated on page 57 did not fit into the above mentioned objections. However, the spectication of the onset of orat therapy is to some 
extent arbitrary. For, during the lirst days of oral therapy, there will still be a substantial, yet gradually decreasing share of the initial intravenously administered ritodrine on the ritodrine serum level. So relative gain was calculated as well as after 24,48 and 72 hours after the onset of oral therapy. Finally a comparison was made between the $R$ - and P-group. not based on the onset of therapy, but based on expected smilar ritodrine serum levels which could be oblained by oral therapy. According to fig. 6-5 the serum levels of ritodrinetreated patients after 72 hours were more or less comparable with the ritodrine serum levels in the placebo group 48 hours after the onset of therapy.

The relative gain is shown in table $\mathrm{V}-12$

Table V-12: Relarive Gain.

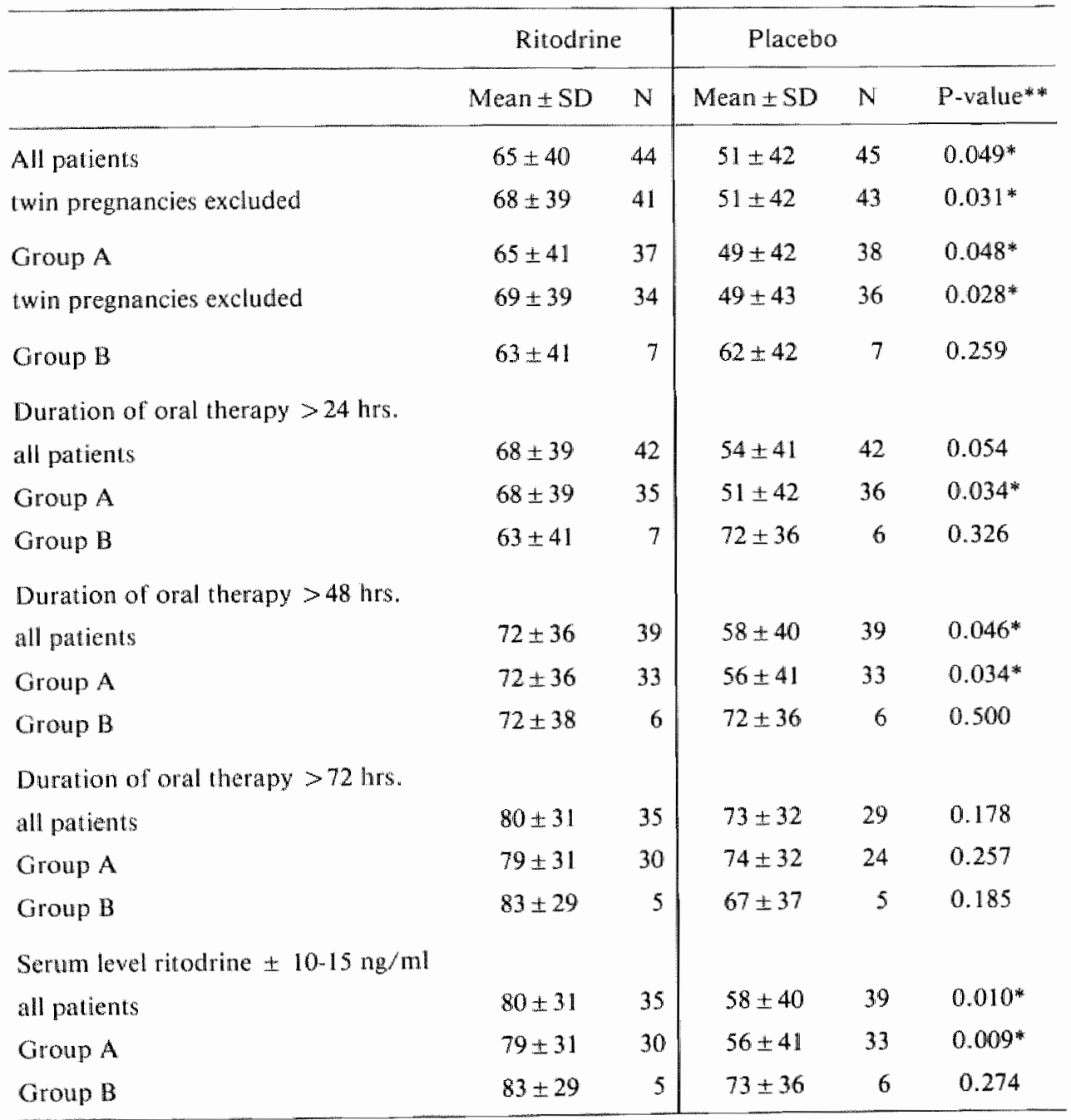

* Significantly different from the placebo-group at $p>0.05$.

* One sised Mann-Whitruey U test (Wilcoxon).

Group A: onset of oral therapy before the end of the $35^{\text {th }}$ week of pregnancy.

Group B: onset of oral therapy after the $35^{\text {th }}$ week of pregnancy. 
To examine whether the relative gain was influenced by a variable, other than the nature of the tablets, the relative gain has been plotted against maternal age, weight and height, parity, blood pressure and maternal heart rate before treatment, haemoglobin concentration, tocolytic index, frequency of uterine contractions, dose of intial intravenous ritodrine and the onset and duration of intravenous treatment as well.

None of these items showed a correlation with relative gain. The time of onset of oral therapy has shown to influence the outcome of the investigations (table V-12). So a paired test, in which patients of the ritodrine group were paired to patients in the placebo group, according to the amenorrhoea at the onset of oral therapy, was performed. The one-sided Wilcoxon test showed a P-value of 0.023 .

\section{Comparison of the neonatal outcome between the two groups.}

The comparison of the neonatal outcome between both groups is not influenced by a difference in gestational age (table $\mathrm{V}-10$ ), nor by parturitional characteristics (table $\mathrm{V}-13$ ). So if a dissimilarity is present between the offspring in the $\mathbb{R}$ - and $\mathbf{P}$-group, one has to wonder if the medication has attributed to this difference.

Induction of labour was indicated in 4 patients. In the R-group one postterm patient and one patient with emotional distress were supposed to need induction of labour, whereas in the placebo group foetal distress $(1 \mathrm{x})$ and postmaturity $(1 \mathrm{x})$ forced to induction of labour. The indications to perform a Caesarean section have been foetopelvic disproportion ( $3 \mathrm{x})$ and placental abruption $(1 \mathrm{x})$ in the ritodrine group, whereas foetal distress $(2 \mathrm{x})$ and placenta praevia were the indications in the placebo group.

Table V-13 Data concerning parturition

\begin{tabular}{|c|c|c|}
\hline & Ritodine & Placebo \\
\hline Number of patients with induced labour & 2 & 2 \\
\hline \multicolumn{3}{|l|}{ Mean $\pm S D$ of duration of: } \\
\hline first stage (in hours) & $6 \pm 4$ & $7 \pm 6$ \\
\hline second stage (in min.) & $17 \pm 18$ & $18 \pm 22$ \\
\hline \multicolumn{3}{|l|}{ Presentation of the neonate: } \\
\hline occiput & 37 & 42 \\
\hline breech & 7 & 3 \\
\hline \multicolumn{3}{|l|}{ Nature of parturition } \\
\hline spontaneous delivery & 32 & 35 \\
\hline vacuum delivery & 1 & 3 \\
\hline forceps delivery & 6 & 3 \\
\hline caeserean section & 4 & 3 \\
\hline breechextraction & 1 & - \\
\hline \multicolumn{3}{|l|}{ Pathology during parturition } \\
\hline placental abruption & 2 & - \\
\hline haemorrhage post partum & 1 & 1 \\
\hline placenta praevia & - & 1 \\
\hline
\end{tabular}




\begin{tabular}{|c|c|c|c|c|c|c|c|}
\hline & \multicolumn{3}{|c|}{ Ribodrine } & \multicolumn{4}{|c|}{ Placebo } \\
\hline & Mean is SD & Range & N & Mean $\pm S D$ & Range & $N$ & Povalue \\
\hline Birtlt weight (ingr) & $3100 \pm 660$ & $1370-5950$ & 47 & $2900 \pm 540$ & $1480-4200$ & 47 & 0.1370 \\
\hline Length (incm) & $49 \pm 2$ & $44-45$ & 47 & $48 \pm 2$ & 4.3 .52 & 47 & 0.4220 \\
\hline Apgar scone (5 min) & $9 \pm 2$ & $0-10$ & 46 & $9 \pm 2$ & $5-10$ & 46 & 0.1580 \\
\hline $\mathrm{PH}$ (umbart) & $7.25+0.099$ & $6.68-7.39$ & 42 & $\begin{array}{l}7.25+0.08 \\
-0.10\end{array}$ & $6.90-7.41$ & 42 & 0.3250 \\
\hline
\end{tabular}

\section{Table V-15 Details of nearatal montality and morbidity}

Paltient Nr. Treatment Amenorhoea Pathology

andelivery

\begin{tabular}{|c|c|c|c|}
\hline 12 & ritodrine & 39 wiks & $\begin{array}{l}\text { stillbirth, severe congenital cardiac malformations; } \\
\text { onset of therapy: } 351 \text { wks. }\end{array}$ \\
\hline 35 & ritodrine & $29^{10}$ wks & $\begin{array}{l}\text { death within } 14 \text { days post partum; breechextraction, } \\
\text { asphyxia. RDS }\end{array}$ \\
\hline 65 & rillodrine & $36^{5}$ wks & $\begin{array}{l}\text { death within } 7 \text { days post partum; severe congenital } \\
\text { hernia diaphragmatica; onset of therapy: } 32 \mathrm{wks} \text {. }\end{array}$ \\
\hline & $\ldots$ & $\cdots$ & $\ldots \ldots \ldots \ldots$ \\
\hline 5 & placebo & $36^{3} \mathrm{wks}$ & hyperbilirubinaemiat \\
\hline 27 & placebo & $36^{4}$ wks & hyperbilirubinatemia, hypoglycaemia \\
\hline 35 & ritodrine & $36^{5}$ wks & hyperbilirabinaemia \\
\hline 40 & ritodrine & $36^{5}$ wks & hypoglycaemia \\
\hline 44 & placebo & $36^{\prime}$ wks & hypoglycaemia \\
\hline 46 & ritodine & $34^{6}$ wks & $\begin{array}{l}\text { first baby: hyperbilirubinaemia } \\
\text { sccond baby: hyperbilirubinaemiat }\end{array}$ \\
\hline 51 & ribodrine & $35^{6} \mathrm{wks}$ & $\begin{array}{l}\text { first baby: hyperbilirubinaemia, hypoglycacmia, RDS } \\
\text { second baby: hyperbilirabinaemia, hypoglyeaemia }\end{array}$ \\
\hline 52 & placeloo & $3 g^{6}$ wks & Mperbilirubinaemiă, RDS \\
\hline 60 & ritodrine & $36^{6}$ was & thyperbilirubinaemia, cephal haemaroma \\
\hline 71 & placebo & $74 \mathrm{wks}$ & hyperbilirubinaemia \\
\hline 84 & placsbo & $34.3^{3} \mathrm{wks}$ & $\begin{array}{l}\text { first baby: NAD } \\
\text { second batby: hypoglycaemia }\end{array}$ \\
\hline
\end{tabular}

Only small differences between the two groups regarding parturition were found. Statistically, using the Chi-square test, these differences were not significant.

The comparison of the neonatal outcome regarding birthweight, length, Apgar score after 5 mimutes and the acid-base equillibrium, expressed in the $\mathrm{pH}$-value of the umbilical arterial blood, is shown in table V-14. No statistically significant differences were found in these data. 
There were 3 foetal losses, all of mothers receiving ritodrine tablets (table $V_{\text {w }}$ ).

There was a fair distribution of neonatal morbidity between both groups. None of the children born alive at term developed pathology during the first 6 weeks after delivery. From the 31 babies born alive and preterm, two died, 13 developed pathology and the remaining 16 babies required no treatment. Table $V-15$ shows the neonatal morbidity. The diagnoses of hyperbilimbinaemia and hypoglycaemia are based on the criteria of Klaus and Fanaroff (1978).

\subsection{Discussion}

The specific goal of this investigation was to determine whether continuation of oral ritodrine treatment, after initial control of threatening preterm labour by means of the intravenous route resulted in a longer duration of pregnancy. Moreover, attention was. given to the safety of this treatment regarding maternal, foetal and neonatal condition. Because of the double blind design of the study the ritodrine and placebo group were not expected to differ regarding pretreatment characteristics: age, parity, tocolytic index were tested for both groups andshowed no significant differences. This trial started at the beginning of the oral medication, so it was necessary to test again the comparability at the end of the intravenous treatment period. No differences between duration and level of intravenous therapy were found in both groups.

A significant difference in favour of the ritodrine group was found with respect to the relative gain. However, gain in days and prolongation index (both being other parameters for success) did not show significant differences in favour of ritodrine, although for these parameters a trend towards better results for the ritodrine treated patients could be detected.

These results are only to some extent in line with those of Creasy et al. (1980) olthough there have been differences between the present trial and Creasy's investigation with regard to the design of the study, the indications for tocolysis, the cxclusion criteria, the number of patients, route of initial application, the dosage of the oral medication and the evaluation of the results.

In the main the results of our study are in agreement with those found by Keirse (to be published), although small differences existed between these two studies with regard to the design of the study.

An interesting finding was that most of the failures (i.e. patients who needed reinfusion, or patients in whom labour was too far advanced to achieve successful tocolysis) were found within the first 72 hours after the onset of oral medication (start of the second veatment period). 
The reason for these early failures could be the considerable difference in serum levels between the mean ritodrine serum level during intravenous infusion with $200 \mathrm{mcg} / \mathrm{min}$ ( 80 $100 \mathrm{ng} / \mathrm{ml}$ ) and the mean serum levels which are measured after continuous oral ritodrine treatment of $120 \mathrm{mg}$ daily $(10-15 \mathrm{ng} / \mathrm{ml})$ (Chapter 6$)$.

This finding might indicate that oral maintenance therapy has to be considered as a form of therapy-continuation.

When success in terms of relative gain was estimated, 24 and 48 hours after the start of oral medication (moments with lower serum levels) similar significant differences were found. However, 72 hours after the onset of oral medication (no detectable serum levels in the placebo group), no significant difference in relative gain was found anymore. This finding cloes not support the potentially prophylactic value of oral medication. However, one should realize that this conclusion is based on a small number of patients.

Fig. 6-5 shows the profiles of ritodrine serum levels during the reduction of intravenous ritodrine therapy and switching to oral ritodrine or placebo treatment. The scheme of reduction and switching to oral therapy, used to compose these profiles, is the same as the one prewiously described in fig. 5-1.

So one can assume that the ritodrine serum levels of the patients studied in this investigation will be in a similar range as shown in fig. 6-5. The placebo-treated group reached serum levels after 48 hours, similar to those reached by the ritodrine-treated group after 72 hours $(15 \mathrm{ng} / \mathrm{ml})$. When comparing both groups from this "serum level point" still a significant gain in favour of ritodrine was found. There is, however, a bias in this respect, for the two groups were only comparable at the beginning of the oral treatment and after 72 hours almost twice as many patients of the placebo group needed retreatment or delivered, compared to the patients in the ritodrine group.

This latter fact strongly suggests a major influence from the slope of the ritodrine disappearance curve upon the result of the therapy.

When we consider all the patients of this trial, including those in which retreatment was necessary for further prolongation of pregnancy, the outcome of pregnancy in terms of amenorthoea at delivery, birth weight or perinatal morbidity was equal for both groups.

So the better results of the patients treated with orally administered ritodrine, compared to the patients, who received placebo tablets, do not justify the conclusion that oral ritodrine as a maintenance therapy after initial intravenous therapy should be used in clinical practice. For similar results were reached when after relapse of uterine activity during placebo medication, retreatment was applied. However, one has to consider that in those cases considerably higher infusion rates were necessary to restore tocolysis (figure 5-6). This disadvantage should be weighed against the cumbersome oral treatment schedule, which includes a considerable number of unnecessarily treated patients.

Part of the inconvenience of the oral maintenance therapy could probably be resolved by a slow release formulation (retard tablets).

Irrespectively of the treatment schedule, the importance of a gradual decrease in serum level seems to be of utmost importance. 


\section{CHAPTER VI}

\section{Serum levels of ritodrine in clinical practice}

\subsection{Introduction}

Under clinical conditions the efficacy of orally administered ritodrine has been questioned (see Chapter V).

One of the causes of a possible inefficacy could be due to the dose limitations of this route of application; the recommended dose of intravenous ritodrine infusion is about a two to three times higher than the oral dose. If one considers its substantial first pass effect as well, it is questionable whether a high oral dose results in serum levels, comparable to those obtained after intravenously administered ritodrine.

To acquire insight in serum levels after orally administered ritodrine under clinical circurnstances, it may not be justified to use data obtained from non-pregnant volunteers, since drug kinetics during pregnancy differ from those in the non-pregnant state. There is, however, a lack of knowledge of the most elementary pharmacokinetic properties of these agents in women in early labour and that is why it is not surprising that as soon as these agents were used in high dosages for tocolysis, a large number of accidents, even fatal accidents occurred (Kubli, 1977; Milliez et al., 1980). So it is important to gather information of serum levels as they may appear in clinical practice of human tocolysis.

Eadie et al. (1977) pointed out some aspects of these changed pharmacokinetics during pregnancy, eventually resulting in different serum levels. Late pregnancy is associated with a decreased motility in the gastro-intestinal tract. This may slow down the rate of absorption of certain drugs, due to dellayed gastric emptying and thus alter the temporal profile of the plasma levels of these drugs. In case of poorly soluble drugs, absorption might increase. In view of the fast absorption these arguments probably do not play an important role in case of ritodrine. On the other hand, slow gastro-intestinal transit might lead to an increase of metabolism of the drug in the intestinal wall.

Since no data concerning the ritodrine concentration in the faeces are available, the cxact influence which several functions of the gastromintestinal tract have on the serum levels of ritodrine is unknown.

Maternal plasma volume and extracellular fluid volume increase during pregnancy, the former up to $50 \%$ between 30 and 34 weeks of gestation. The increasing body fluid and tissue volumes during pregnancy might be expected to have the effect of lowering the plasma concentration. Also plasma protein concentration tends to fall gradually during pregnancy.

In case of ritodrine with a fast distribution, probably following a one-compartment model and with a low binding capacity to plasma proteins, the hypervolaemia may result in lower serum levels compared to those in the non-pregnant state.

Finally the metabolism in the liver and the excretion by the kidney are increased in 
pregnancy. Progesteronc can induce hepatic microsomal function, speeding up the biotranformation. The increase of the exeretion rate is probably due to the increased glomerular filtration rate.

All these considerations force fo investigate the serum levels of ritodrine in those patients and those circumstances, for whom and for which the drug was developed.

The first question which has been posed, is whether orally administered ritodrine can reach adequate serum levels. To answer this question one needs to know, approximately, the serum levels in pregmant patients with theatening preterm labour who were successfully treated with ritodrine.

A second question is, whether during the oral maintenance therapy a high dose of orally administered ritodrine is sufficient to maintain a stable serum level or whether the ritodrine serum levels fluctuate. The ritodrine serum levels were also correlated to the maternal heart frequency, which is clinically known to fluctuate during the course of time between two applications of the drug.

To elucidate some aspects of these questions, serum levels were measured during:

- the initial period of treatment by intravenously administered ritodrine,

- the process of reducing the intravenous the rapy and switching to oral therapy,

- the oral maintenance therapy.

The determinations of the ritodrine serum levels were performed at the Duphar Research Laboratories, by the radioimmunoassay methodology previously published by Gandar et al. (1980) and Thomas et al. (1982).

The cross-reaction study revealed no significant interference by either other beta-mimetic drugs or various protein homones and steroid hormones investigated (Thomas et al., 1982); The cross-reactivity with ritodrine metabolites (glucoronide and sulfate conjugates) was estimated to be less than $0.2 \%$ (Gandar et al., 1980). The sensivity of the radioimmunoassay appeared to be about $0.1 \mathrm{ng} / \mathrm{ml}$ (Thomas et al., 1982).

6.2. Serum levels during the initial period of intravenous ritodrine treatment (first treatment period)

In a clinical setting the dose of effective intravenous treatment varies from $50 \mathrm{mcg} / \mathrm{min}$ up to $1000 \mathrm{mcg} / \mathrm{min}$. Non-responding cases, despite high doses of ritodrine, are not uncommon.

This is not amazing if one realizes that the patients with threatening preterm labour form a heterogeneous group with respect to the dilatation and effacement of the cervix, the state of the membranes and the presence or absence of vaginal blood loss. Baumgarten and Gruber (1974) assessed these obstetrical qualities, resulting in a tocolytic index.

The rate of success of tocolytic treatment was found to be related to the tocolytic index. To answer the ult mate question whether oral ritodrine in a high dose can result in an "effective" serum level one has to gather knowledge about the range of therapeutic serum levels in clinical practice. The initial period of intravenous ritodrine treatment seems preeminently suitable to follow the relationship between serum level and clinical effect and so to find a possible therapeutic serum level for those patients in those circumstances. 


\section{Patients and methods}

The investigations have been carried out in patients with threatening preterm labour who received no other treatment than ritodrine and bed rest.

The diagnosis of preterm labour was made at a gestational age of less than 37 weeks if uterine contractions occurred at least every $6 \mathrm{~min}$. and were present for at least 2 hours. A patient was eligible for entering the study if gestation was between 20 and 37 weeks and there should be no medical and/or obstetrical contra-indication for ritodrine treatment (table-V-1).

Ritodrine was administered by a infusion pump with a flow rate of 0.0 to $9.9 \mathrm{ml} /$ hour (Vickers Medical Treonic digital syringe pump).

Ritodrine $200 \mathrm{mg}(=20 \mathrm{ml})$ and heparine $500 \mathrm{U}(=2 \mathrm{mll})$ were added to $28 \mathrm{ml}$ normal saline, providing a concentration of $4 \mathrm{mg} / \mathrm{ml}$.

The infusion with ritodrine was started at a level of $100 \mathrm{mcg} / \mathrm{min}$. and was increased by 33 $\mathrm{mcg} / \mathrm{min}$ at every 15 minutes interval untill contractions stopped or unacceptable side effects developed. This dosage was maintained during at least 48 hours. This initial period of intravenous ritodrine treatment was called the first treatment period.

If there was a duration of amenorrhoea of less than 36 weeks and there were no contraindications for the continuation of tocolysis (table V-1), the route of application of ritodrine was switched from intravenous to oral medication, as shown in fig. 6-1.

i. v. ritodrine ( $\mathrm{mcg} / \mathrm{min})$

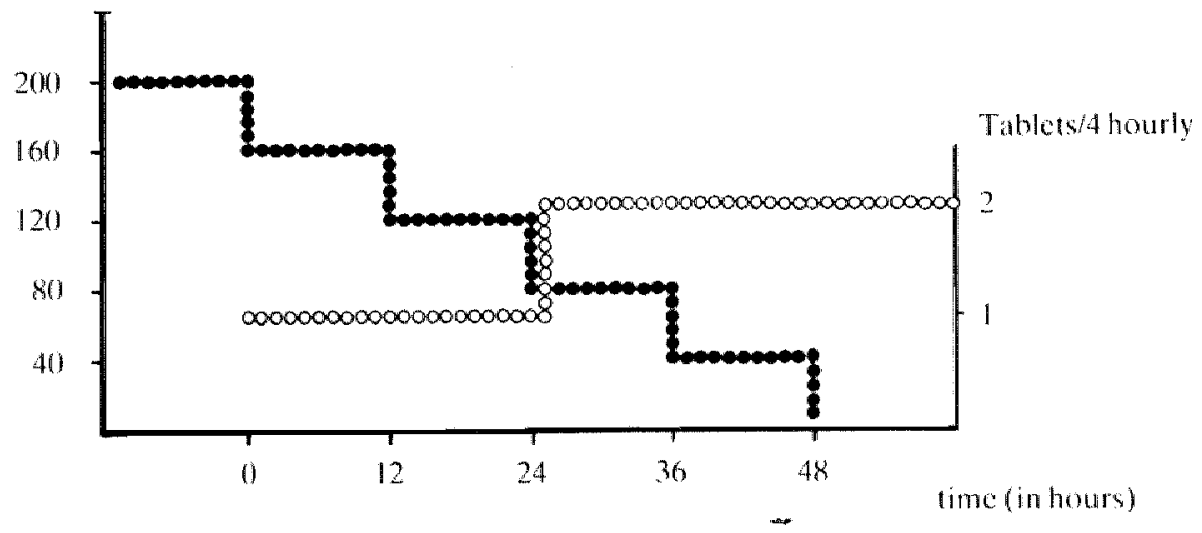

Fig. 6-1 Scheme of reduction and swithing to oral therapy

If the infusion rate was more than $200 \mathrm{mcg} / \mathrm{min}$ in the first treatment period, the dose was gradually reduced to $200 \mathrm{mcg} / \mathrm{min}$. If no uterine contractions were reconded at this dose during 2 days, a further reduction by $1 / 5$ th of the dose every 12 hours was effected (1otal duration: 48 hours). Oral medication was inchoated from the start of reducing the dosage of $200 \mathrm{mcg} / \mathrm{min}$ intravenously administered ritodrine: the first 24 how rs one tablet of $10 \mathrm{mg}$ ritodrine every 4 hours; the second 24 hours two tablets 4 hourly. This process of reducing and switching from intravenous to oral therapy was referned to as the second treatment period. 
After these 48 hours the infusion system was removed and the patients were gradually mobilized. If no maternal and/or foetal contra-indications were present, the oral maintenance therapy was continued until the 259 th day of pregnancy.

Five patients fulfilling the criteria as described above, have been studicd during the initial period of intravenous ritodrine treatment (first treatment period).

Their characteristics are listed in table VI-1. The course of pregnancy of patient $E$ is described separately.

Table VI-1 Chapacteristics of the patients studied during the first treatment period

\begin{tabular}{|c|c|c|c|c|c|}
\hline & A & $\mathrm{B}$ & $\mathrm{C}$ & $D$ & E \\
\hline Age & 24 & 28 & 21 & 32 & 38 \\
\hline Parity & 0 & 0 & 1 & 1 & 0 \\
\hline Length (cm) & 158 & 164 & 160 & 158 & 152 \\
\hline Weight (kg) & 58 & 66 & 54 & 80 & 55 \\
\hline Smoking habits (cigaretres a day) & - & 10 & $10-15$ & 10 & 25 \\
\hline Previous history & - & - & $\begin{array}{l}\text { preterm } \\
\text { birth }\end{array}$ & - & spont ab. \\
\hline Am. onset of threat. preterm labour & $25^{3}$ & $35^{2}$ & 28 & $32^{5}$ & $31^{2}$ \\
\hline Am. onset of $1 . \mathrm{V}$. treatment & $25^{5}$ & $35^{2}$ & $28^{1}$ & $32^{5}$ & $31^{2}$ \\
\hline $\mathrm{Hb}(\mathrm{mmol} / \mathrm{ll})$ & 6.8 & 6.6 & 6.6 & 7.3 & 6.7 \\
\hline Effacement of cervix & -- & $100 \%$ & $50 \%$ & $50 \%$ & $100 \%$ \\
\hline Dilatation $(\mathrm{cm})$ & 1 & 2 & 1.2 & $1-2$ & 2 \\
\hline State of membranes & intact & intact & intact & intact & intact \\
\hline Boolding & - & - & - & - & - \\
\hline Contractions hour & 15 & 10 & 20 & 20 & 15 \\
\hline Tocollytic index & 3 & 4 & $3-4$ & $3-4$ & 4 \\
\hline Discongumention & - & - & - & - & $\begin{array}{l}\text { polyhy- } \\
\text { dramnios }\end{array}$ \\
\hline Maximaldose (neg/mim) & 200 & 200 & 200 & 200 & 2000600 \\
\hline Am. cond W & $26^{1}$ & $35^{6}$ & $28^{5}$ & 36 & 33 \\
\hline Decursus & $\begin{array}{l}\text { ord Rit. } \\
\text { till } 37 \text { wk. }\end{array}$ & $\begin{array}{l}\text { obser. } \\
\text { Vation }\end{array}$ & $\begin{array}{l}\text { oral Rit. } \\
\text { till } 36^{2} w \mathrm{k} .\end{array}$ & $\begin{array}{l}\text { obser- } \\
\text { vation }\end{array}$ & $\begin{array}{l}\text { non- } \\
\text { responding }\end{array}$ \\
\hline Ame partus & 38 & $36^{2}$ & $36^{2}$ & 38 & 33 \\
\hline Birih weight (granm) & 3090 & 2550 & $3 \llbracket 20$ & 2840 & 2100 \\
\hline
\end{tabular}


Prior to the enhancements of the infusion rate, serum samples were drawn from the contralateral cubal vein. In this way it was possible to obtain the serum level of ritodrine at the moment of complete tocolysis and in this way some insight in the height of the therapeutical serum level could be obtained.

A sample, 3 hours after the tocolysis had been shown to be successful, and a sample prior to a change in the infusion rate (at least two days after the onset of treatment) were collected to determine serum levels during the steady state.

\section{Results}

The serum levels obtained from these 5 patients were considered to be suitable for compilation because of the similarity of their treatment scheme.

The mean of the ritodrine serum levels and its range during the initial intravenous therapy have been listed in table V1-2 and graphically plotted in figure 6-2.

The contraction frequency measured at the onset of treatment was $16 \pm 4,2$ contractions per hour (mean $\pm S D$ ). The frequencyand intensity of the contractions decreased gradually to zero after 45 minutes.

Table V1-2 Ritodrine serum level (ng/ml) during the initial period of i.v. (reatment $(\mathrm{N}=5)$

\begin{tabular}{lcc}
\hline Time & Mean \pm SD & \multicolumn{1}{c}{ Range } \\
\hline $15 \mathrm{~min}$ & $1.7 \pm 2.7$ & $0.2-6.5$ \\
$30 \mathrm{~min}$ & $25.3 \pm 10.6$ & $9.2-36.3$ \\
$45 \mathrm{~min}$ & $41.2 \pm 6.7$ & $31.7-48.9$ \\
$60 \mathrm{~min}$ & $46.7 \pm 10.1$ & $33.0-57.0$ \\
4 hours & $90.5 \pm 6.5$ & $41.3-98.0$ \\
$\geq 2$ days & $102.7 \pm 12.3$ & $91.0-123.0$ \\
\hline
\end{tabular}

It was assumed that the 60 minutes serum lewel was in the therapeutical range for these patients and in these circumstances because no more contractions had been registrated since the preceding 15 minutes. Without further enhancenents of the dosage the serum levels doubled in the next two days. 


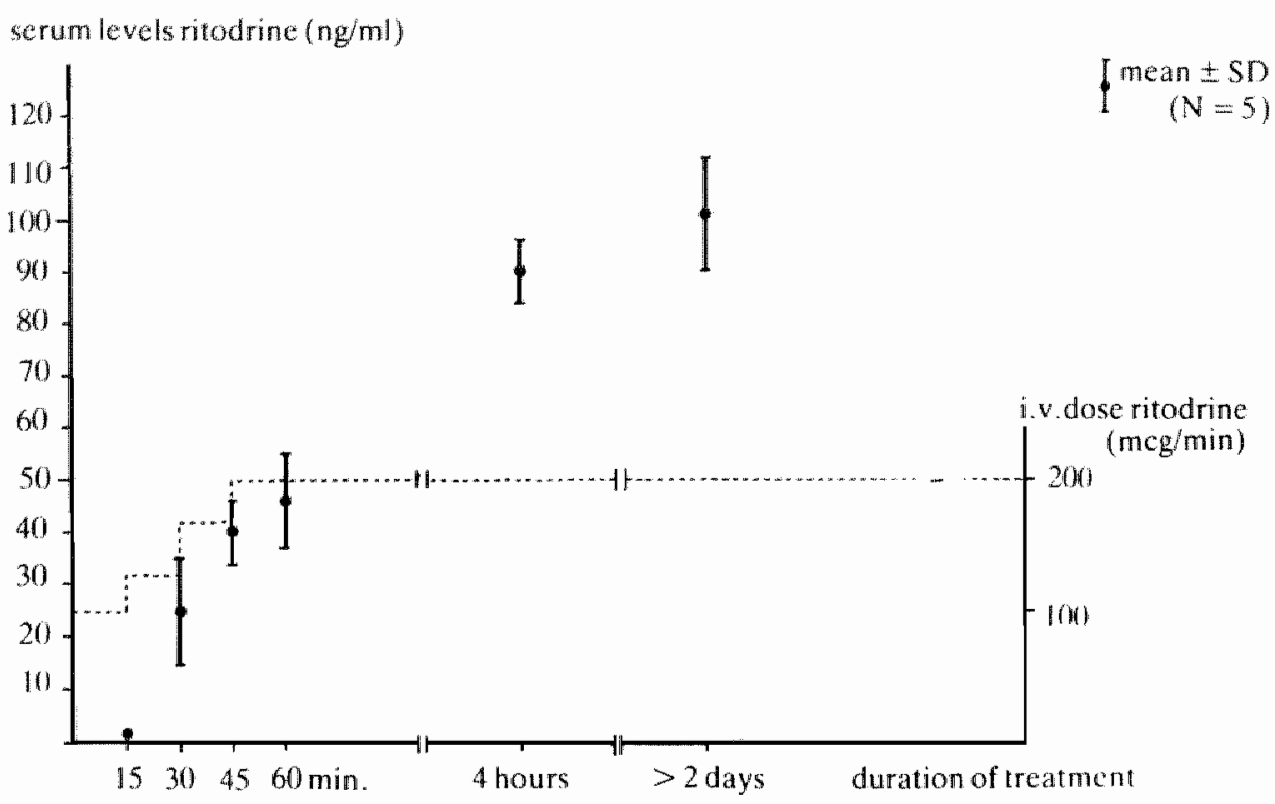

Fig. 6.2 Ritodrineserumlevels during the initial period of i.v.treatment

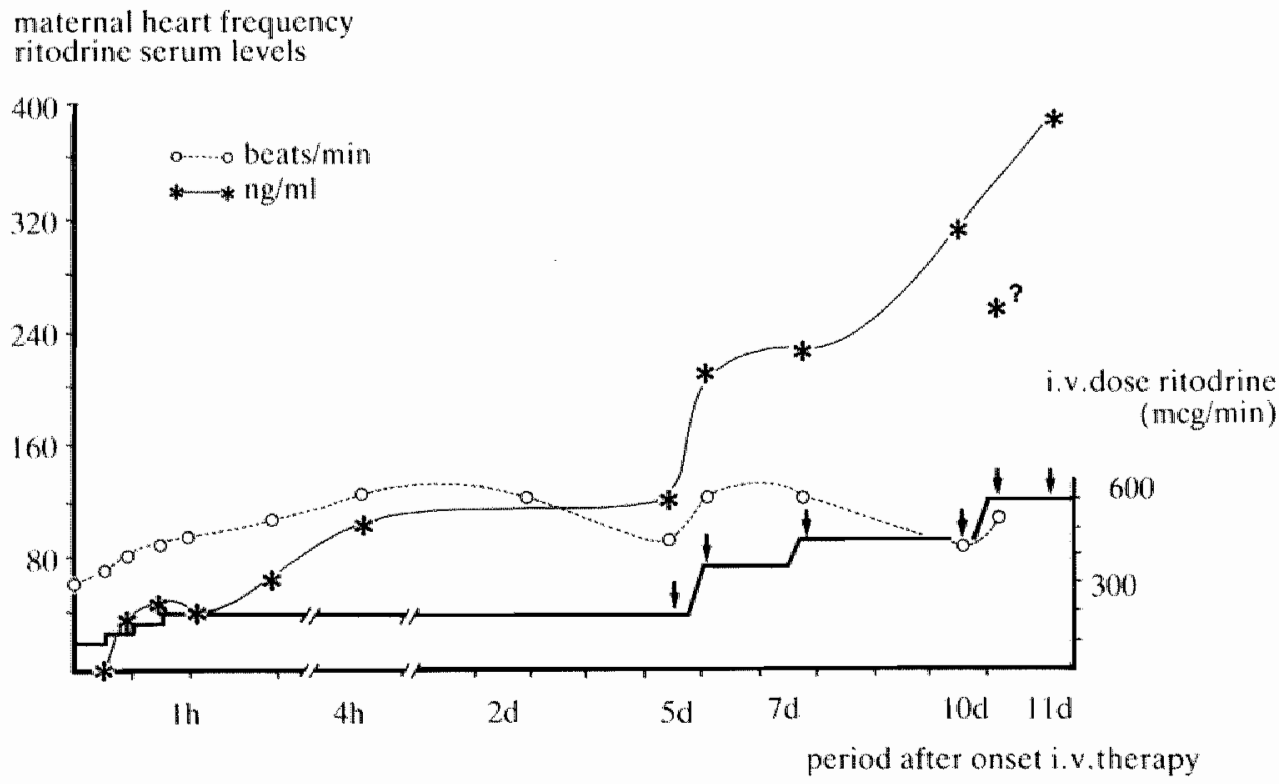

Fig. 6-3 A case hisromy 
Patient $A$ is a 38 -year-old nullipara.

During the course of the present pregnancy polyhydramnios developed, which ultimately resulted in preterm uterine activity.

On day 219 of pregnancy tocolytic therapy by means of intravenous ritodrine was started initially successful with $200 \mathrm{mcg} / \mathrm{min}$. Because of recurrence of uterine activity it was necessary to increase the infusion rate on the 5 th, 7 th and finally on the 10 th day after the onset of therapy. This resulted in an infusion rate of $600 \mathrm{mcg} / \mathrm{min}$ with concomitantly high serum levels.

During the 11 th day of treatment it became clear that there was progression in dilation of the cervix as a result of the non-inhibitable uterine activity and so treatment was withdrawn.

On the 11 th day after the onset of therapy a healthy son with a birth-weight of $2100 \mathrm{grams}$ was born. No cause with regard to the polyhydramnios was found.

\subsection{Ritodrine serum levels during the reduction of intravenous therapy and switching to oral treatment (second treatment period)}

In the introduction of this chapter the question was raised whether or not therapeutic serum levels could be obtained with orally administered ritodrine.

The switch from intravenous to oral treatment, as described, offered good opportunity to compare the serum levells before and after this procedure in one and the same patient.

In these patients $200 \mathrm{mcg} / \mathrm{min}$ have proved to be a therapeutic dose; however, the possibility is still present that even with a lower dose of intravenously administered ritodrine complete tocolysis could have been obtained.

To elucidate the share of the oral medication in the serum levels obtained during the reduction and switching phase, serum levels were also collected from patients, whose intravenous reduction scheme was the same as the one of the studied patients, but who received placebo tablets instead of ritodrine tablets.

It has to be stressed that the comparison is only of value in the pharmacokinetic point of view? the pharmacodynamic aspect cannot be judged because the biological effect, i.e. the inhibition of uterine contractility, had already been achieved during the initial intravenous treatment period.

\section{Patients and methods}

Eight patients from the population as described in chapter 6-2 were observed during and after the procedure of reducing and switching from intravenous to oral ritodrine treatment.

Four patients, receiving placebo tablets, served as control patients. The summarized characteristics of these patients in whom the investigations have been carried out, as well as the characteristics of 4 patients in the control group are listed in table VI-3. 
Table V1.3 Characteristics of the patients studied during the second treatment period

\begin{tabular}{lrr|rr}
\hline & \multicolumn{2}{c||}{ Ritodrine( $=8)$} & \multicolumn{2}{c}{ Placebo(n=4) } \\
\hline & Mean \pm SD & Range & Mean \pm SD & Range \\
\hline Age (years) & $24 \pm 4$ & $17-31$ & $23 \pm 2$ & $22-25$ \\
Parity & $0 \pm 0$ & $0-1$ & $0 \pm 0$ & $0-1$ \\
Length (cm) & $164 \pm 6$ & $155-173$ & $161 \pm 7$ & $151-169$ \\
Weight (kg) & $64 \pm 6$ & $60-78$ & $62 \pm 4$ & $58-68$ \\
Sinoking habits (cig/day) & $9 \pm 7$ & $0-25$ & $3 \pm 4$ & $0-10$ \\
Onset of IV treatment (days) & $226 \pm 18$ & $193-255$ & $223 \pm 23$ & $189-245$ \\
\hline
\end{tabular}

The scheme of blood sampling is shown in figure 6-4.

Sample 1 was drawn when the patient was still on full intravenous treatment. Sample 2 was taken one hour after the IV dosage was reduced to $60 \%$ plus 1 tablet $(=10 \mathrm{mg}$ ritodrine or placebo).

The 3 rd sample was taken when the dosage was reduced to $40 \%$ plus 2 tablets. Sample 4 was drawn one hour after the intravenous ritodrine was reduced to zero. Sample 5,6 and 7 were taken the next consecutive days. Blood samples were collected one hour after the application of the oral medication because it was thought that the effect of the orally administered ritodrine was maximal at that particular moment.

i.v.dose ritodrine $(\mathrm{mcg} / \mathrm{min})$

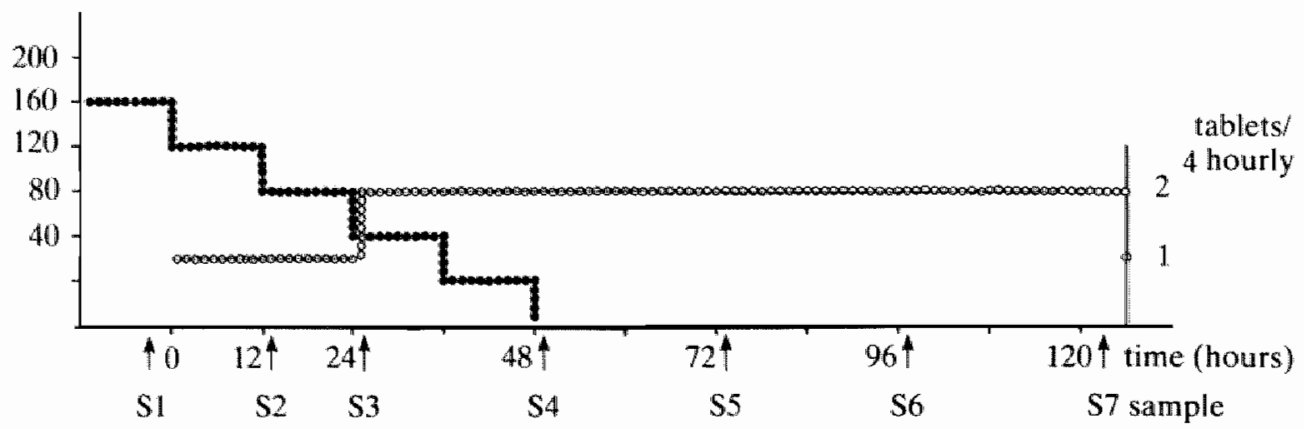

Fig. 6.4 Scheme of blood sampling during the second treatment period (arrows indicate moments of blood sampling) 


\section{Results}

The results have been listed in table VI-4 and graphically plotted in figure 6-5.

Table VT-4 Ritodrine serum levels during the second treatment period in (ng/ml)

\begin{tabular}{|c|c|c|c|c|}
\hline & \multicolumn{2}{|c|}{ Ritodrine $(\mathrm{n}=8)$} & \multicolumn{2}{|c|}{ Placebo $(n=4)$} \\
\hline & Mean $\pm S D$ & Range & Mean $+S D$ & Range \\
\hline$\$ 1$ & $74.4 \pm 14.4$ & 53.0 .99 .3 & $101.8 \pm 59.8$ & $47.8 \cdot 186.0$ \\
\hline$\$ 2$ & $60.2 \pm 19.1$ & $34.5-97.9$ & $64.7 \pm 16.4$ & $42.2-81.0$ \\
\hline 53 & $48.9 \pm 14.9$ & $29.3-71.0$ & $37.1 \pm 20.4$ & $19.4 \cdot 66.3$ \\
\hline$\$ 4$ & $29.7 \pm 5.5$ & $22.4-36.2$ & $16.9 \pm 6.8$ & $10.9-26.4$ \\
\hline $\mathrm{S} 5$ & $14.8 \pm 6.3$ & $10.0-29.7$ & $2.9 \pm 3.2$ & $0.9 . \quad 7.7$ \\
\hline S6 & $12.1 \pm 3.4$ & $8.9-19.0$ & $0.6 \pm 0.1$ & $0.5-0.7$ \\
\hline S7 & $10.5 \pm 3.8$ & $7.4-15.6$ & nd & \\
\hline
\end{tabular}

nd $=$ not detected

serum level ritodrine $(\mathrm{ng} / \mathrm{ml})$

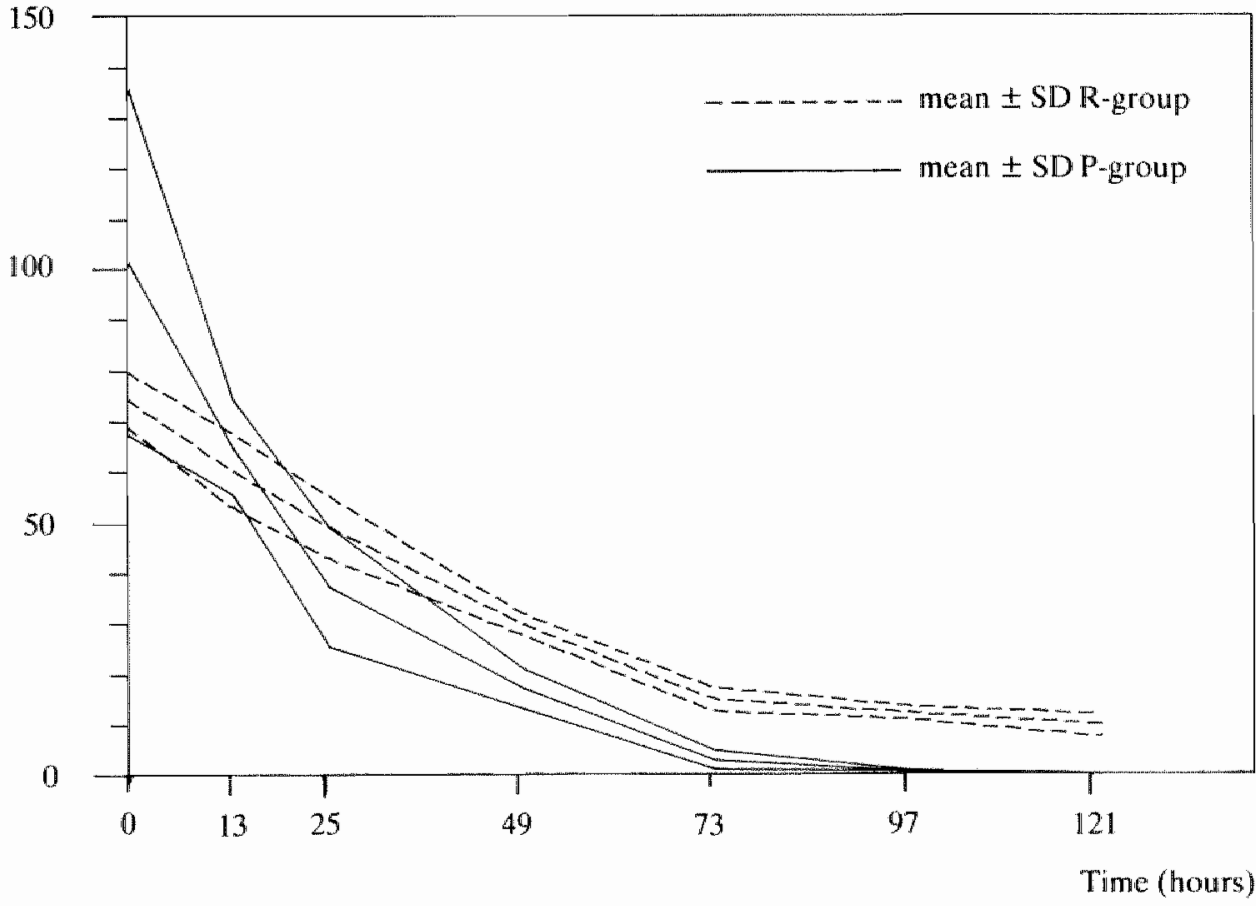

Fig. 6-5 Ritodrine serum levels during the second treatment period 
The mean of the serum levels in the placebo group appeared to be higher than in the ritodrine group, probably because of one patient with a relative high serum level.

The mean $\pm \mathrm{SD}$ of the ritodrine serum levels of all patients $(\mathrm{N}=12)$ determined before the process of reducing the intravenous therapy and switching to oral treatment was commenced (fig. 6-4: sample 1) was $83.3 \pm 23.2 \mathrm{ng} / \mathrm{ml}$. Though this level is slightly lower, it is not significantly different from the serum levels during the steady state of the first treatment period, as shown in fig, 6-2.

The area under the curve (A.U.C.) after 25 hours (sample 3) of the ritodrine-treated patients was significantly larger compared to the A.U.C. of the placebo-treated patients (calculated using the statistical package according to Zerbe and Walker, 1977).

\subsection{Serum levels during oral maintenance therapy (third treatment period)}

Many patients complain of side effects, especially palpitations, during oral ritodrine maintenance therapy.

According to these patients the maximal discomfort appears about $30-90$ minutes after swallowing the tablets.

Another feature noticed by some patients, while taking high doses of orall ritodrine, is an increasing number of contractions in proportion to the passage of time between two applications of the drug.

Post (1977) and van Lierde et al. (1981) found a striking correlation between serum level and the maternal heart rate.

These clinical observations together with the above-mentioned relationship have thrown doubts upon the stability of the ritodrine serum levels during oral maintenance therapy. So ritodrine serum levels were measured in a number of patients during oral maintenance therapy, to gather knowledge about the relationship between maternal heart rate and serum levels versus time.

\section{Patients and methods}

Six patients who had an uneventful first and second treatment period participated in this study. These patients have been on orat therapy for at least 3 full days ( $20 \mathrm{mg}$ ritodrine per os 4 hourly). The characteristics of these paticuts are shown in table VI-5.

Table VI.5 Characteristics of the srudied patients during the third treatment period

\begin{tabular}{lrr}
\hline & Mean \pm SD & Range \\
\hline Age (years) & $23 \pm 2$ & $21-27$ \\
Parity & $0 \pm 0$ & $0-1$ \\
Lingth (cm) & $160 \pm 7$ & $149-169$ \\
Weight (kg) & $58 \pm 7$ & $46-66$ \\
Smoking habits (cig/day) & $8 \pm 7$ & $0-20$ \\
Onset ofi. w. treatment (days) & $203 \pm 22$ & $175-228$ \\
\hline
\end{tabular}


During the study period patients were asked to stay in bed in order to exclude as much as possible the influence of exercise on the maternal heart rate.

The maternal heart rate was monitored by an automatic blood pressure equipment (Doppler system).

Blood samples were taken one minute prior to the application of the oral dosage (moment 0 ), as well as $30,60,90,120$ and 240 minutes after taking the tablets. At moment 240 the next gift was applied.

\section{Resullits}

The results are listed in table VI-6 and graphically plotted in figure 6-6.

Table VI-6 Ritodrime serum levels and matemal heart rate during oral maintenance therapy $(\mathrm{N}=6)$

\begin{tabular}{|c|c|c|c|c|}
\hline & \multicolumn{2}{|c|}{ Maternal heart rate (beats/min) } & \multicolumn{2}{|c|}{ Ritodrine serum level (ng/ml) } \\
\hline & Mean $\pm S D$ & Range & Mean $\pm \mathrm{SD}$ & Range \\
\hline $0 \mathrm{~min}$ & $93 \pm 10$ & $78-102$ & $10.6 \pm 5.9$ & $6.1-19.6$ \\
\hline $30 \mathrm{~min}$ & $90 \pm 12$ & $75-104$ & $9.9 \pm 5.5$ & $3.2-16.7$ \\
\hline $60 \mathrm{~min}$ & $100 \pm 17$ & $80-127$ & $12.4 \pm 5.5$ & 8.221 .6 \\
\hline $90 \mathrm{~min}$ & $109 \pm 17$ & $85-129$ & $18.7 \pm 8.2$ & $10.4 \times 30.5$ \\
\hline 120) min & $103 \pm 15$ & $81-120$ & $15.1 \pm 7.8$ & $6.5 \cdot 24.1$ \\
\hline 240 min & $92 \pm 9$ & $83-102$ & $7.1 \pm 2.1$ & $4.8-10.2$ \\
\hline
\end{tabular}
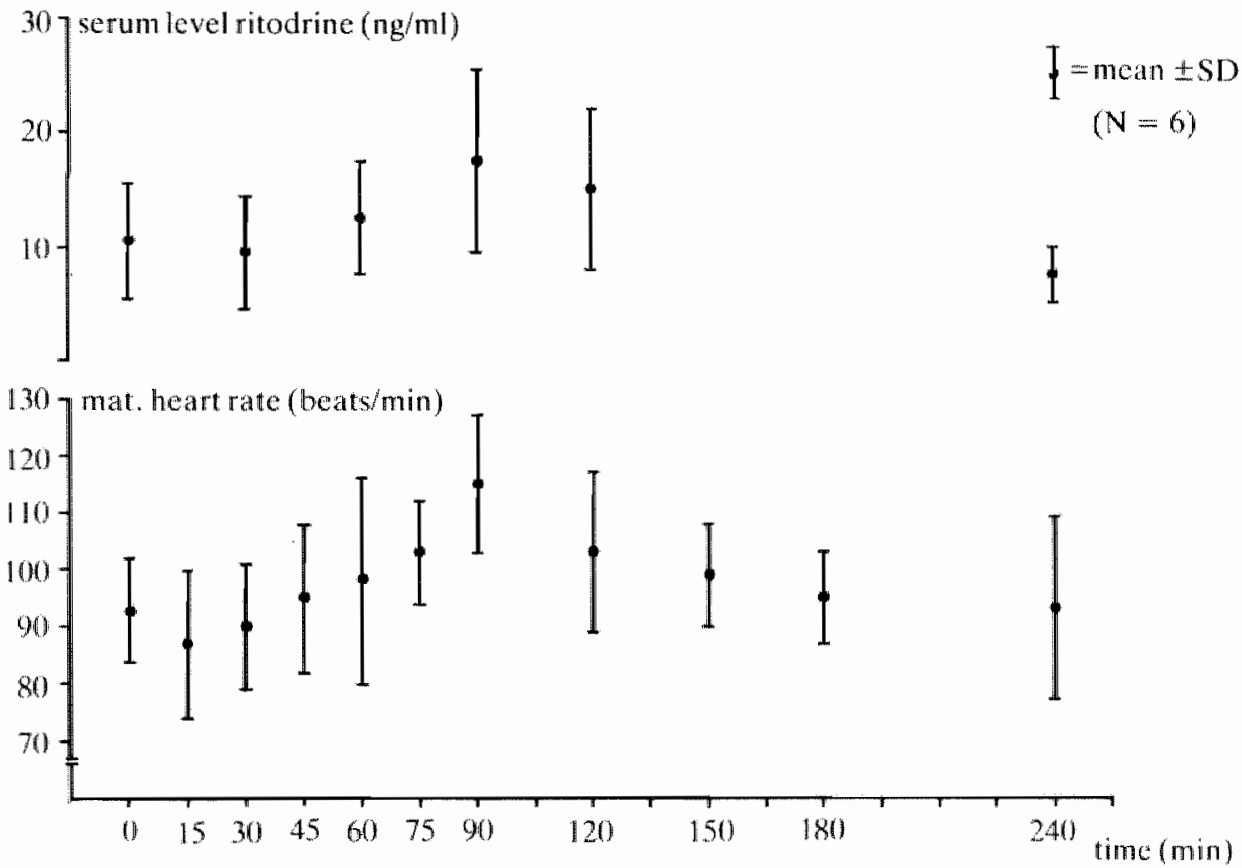

Fig 6-6 Ritodrine serum levels and maternal heart rave during oral maintenance therapy 
The relation between the ritodrine serum levels and the maternal heart rate between two applications has been plotted in figure 6-7. The correlation coefficient appeared to be 0.7634 .

ritodrine serum level $(\mathrm{ng} / \mathrm{ml})$

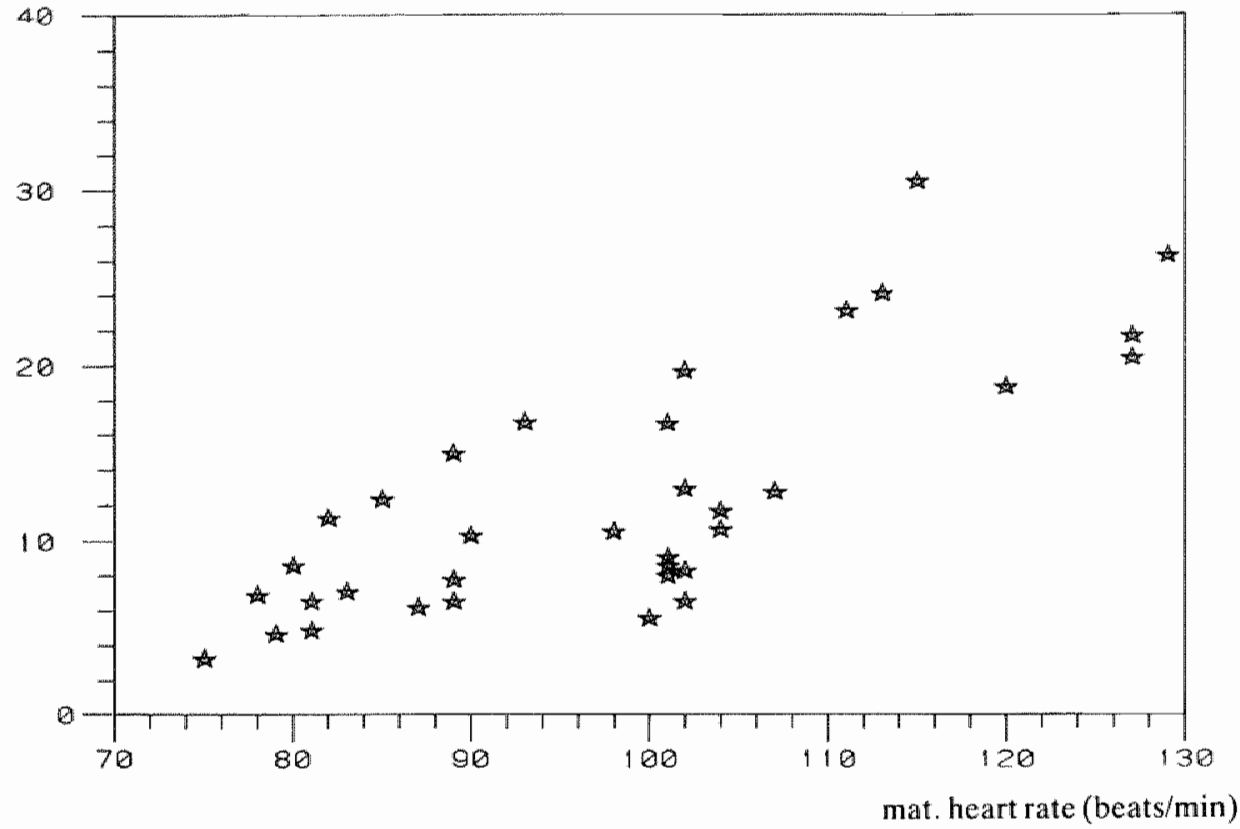

Fig. 6-7 Relation beween ritodrine serum levels and maternal heart rate daring oral maintenance therapy

\subsection{Discussion}

Until recently very little was known about the pharmacokinetics of beta-sympathomimetic drugs, used for tocolysis, although during the last 10 years there is an increasing use of the drugs in many countries (Ritchic and McClure, 1979). This is all the more striking when we realize that the dosage levels necessary to achieve satisfactory tocolytic results, are several times higher thitn those used in other medical disciplines, for example in case of pulmonary diseases.

Only fractional data were published, concerning pharmacokinetic profiles of fenoterol, ritodrine, salbumatol and terbutaline in animal experiments and/or in non-pregnant volunteers. Only recently ritodrine serum levels were measured in pregnant women by van Lierde et al. (1981) and non-pregnant volunteers by Post (1977), but this was done in single dose experiments with women who were not in labour and accordingly no high dose levels were reached.

From the results of the present investigation during the first treatment period (fig. 6-2) it is clear that a steady state in serum level is reached within hours from the start of the medication and this level does not alter significantly for days when the infusion rate is kept 
on the same dosage. When analyzing the first hours of the infusion, it is shown that from the moment the infusion rate is not further increased there is still an increase of the serum level of ritodrine.

One clinical implication of these findings may be that when tocolysis is achieved as a result of a certain infusion level, it should be possible after a steady state of some hours to reduce the infusion rate while keeping the same serum level.

Secondly, it is clear from these findings that the serum levels, corresponding with a certain infusion rate, measured in single dose experiments, are lower than those actually measured in a steady state of ritodrine treatment. So the corresponding serum level of $200 \mathrm{mcg} / \mathrm{min}$ was found to be $45 \mathrm{ng} / \mathrm{ml}$ (van Lierde et al. 1981) but in this experiment this figure was found to hold only for the first hour ritodrine infusion of $200 \mathrm{mcg} / \mathrm{min}$ but when keeping the infusion rate at the same level, a further increase in the serum level up to $100 \mathrm{ng} / \mathrm{ml}$ was found

As usual in clinical practice the dosage was administered according to a standard treatment and no adjustment to body weight has occurred. The dosage used in the present study varied between $2.5-3.7 \mathrm{mcg} / \mathrm{min} / \mathrm{kg}$ bodyweight, which is in the same range as used by van Lierde.

From the results obtained in the second treatment period (fig. 6-5) it appears that oral medication as administered in this investigation can only compensate for intravenous treatment below a level of about 20 per cent of the original dose; this corresponds with 40 mcg/min. Roughly speaking this figure could have been calculated as well, taking in account the considerable first pass effect of orally administered ritodrine (70 per cent; Post, 1977) and a dose of $120 \mathrm{mg} / 24 \mathrm{hours}$ ( $=83 \mathrm{mcg} / \mathrm{min}$ ).

So there seems little sense in oral therapy before the infusion rate has been decreased to this level. However, from the studies in chapter $V$ it was concluded that the slope of the serum level may be of influence on the success of tocolytic treatment and some value of orally administered ritodrine before the serum levels of $\pm 15 \mathrm{ng} / \mathrm{ml}$ was reached, could be attributed to the more gradual slope of the disappearing curve.

This argument in favour of oral ritodrine could be obviated by an even more gradual decrease of the intravenous dosage.

In view of the low serum levels during oral maintenance therapy, fluctuations in thos: levels will be relatively more unfavourable with regard to the continuation of the tocolytic effect when compared to intravenous therapy. A certain constant level is hardly reachod as has been shown in fig. 6-6. Almost $100 \%$ differences were measured between the moment just prior to the application of $20 \mathrm{mg}$ ritodrine and 90 minutes after this moment.

Another interesting fact derived from this investigation is the intra- and interindividual spread, which was found to be much larger in the oral compared to the intravenous steady state.

A second interesting fact shown by the results from figure 6-7 is the good correlation between the maternal heart frequency and the measured scrum level. These findings are in agreement with the results of Post (1977) and wan Lierde (1981) in non-pregnant and pregnant volunteers, respectively.

It should be emphasized that this investigation has been carried out in a hospital setting with supervision of the intake of medicine. One has to wonder how large the "paticnt 
compliance" will be when a patient is discharged from hospital, without the experience of uterine contractions but with palpitations. Without a motivating supervisor and frequent out-patient visits it is imaginable that less frequent than 6 times a day the tablets will be taken. This latter fact will result in even greater fluctuations of the ritodrine serum levels and the concomitant tocolytic effect.

So if there is an indication for oral therapy the pharmacokinetic problem of the fluctuations. in the serum levels and the problem of the patient compliance have to be solved, probably by means of a sustained release form of the oral medication.

Finally, from the measured serum levels during oral maintenance therapy it is clear that there is no sense in using oral medication for initial treatment; the dosage levels reached by very high oral administration were found to be only a fraction of those obtained by an average intravenous application of $200 \mathrm{mcg} / \mathrm{min}$. 


\section{SUMMARY}

Preterm birth is the main cause of perinatal mortality and morbidity. Up to now no unanimous cause is known, which can explain the preterm onset of parturition. The fact that the mechanism of the onset of term-labour is not fully elucidated contributes to this non-unanimity. In the literature various mechanisms with regard to the onset of labout have been suggested on which points of impact for the therapy of preterm labour are based: ethanol, beta-mimetic drugs, prostaglandin synthesis inhibitors, calcium antagonists and bedrest.

Due to the incomplete understanding of (preterm) parturition it is difficult to distinguish true labour and false labour. Therefore in the literature differences in definition regarding. preterm birth exist, especially with regard to the duration of amenorrhoea and birthweight.

Chapter II reviews the above mentioned problems. In this chapter attention is also paid to the changes which occur in the myometrium during the course of pregnancy.

From the literature it appears that the occurrence of regular uterine activity goes together with the formation of "gap junctions". The appearance of these gap junctions are probably due to hormonal changes. In this regard oestrogens and progesterone are of importance. Besides these prostaglandins and beta-sympathomimetic agents play a role.

During the course of pregnancy serum concentrations of several agents which influence the formation of gap junctions, change. In this chapter, literature is reviewed regarding oestrogens, progesterone and their mutual relation.

Furthermore attention is paid to corticosteroids, oxytocin, prostaglandins and catechollamines.

In to-day's obstetrics beta-sympathomimetic drugs are the most frequently used agents for the inhibition of threatening preterm labour. Chapter III reviews the pharmacological aspects of these drugs, in pregnant and non-pregnant women as well as in animals. Special attention is paid to serum levels of these drugs. It appears that beta-sympathomimetic drugs are capable to inhibit uterine activity. This quality is dependant of its structural formula.

The way of action is probably the interference in the adenylcyclase-cAMP mechanism which finally results in a decrease of the unbound intracellular calcium.

In chapter IV the results are described of a longitudinal investigation regarding the serum concentrations of oestradiol, oestriol and progesterone during the course of pregnancy in relation to uterine activity.

For this purpose these hormones, as well as the uterine activity have been determined in eighty healthy primigravid women up to the 37 th week of pregnancy. The uterine activity was objectivated by means of external tocodynamometry. At the same time the subjective uterine activity has been registered.

It appears that there is a gradual increase of all the three mentioned hormones during the course of pregnancy. However, there is a large interindividual spread. There is no relation between the hormonal serum levels and uterine activity (objectivated as well subjective uterine activity). 
There is a poot relation between the subjective uterine activity and the objectivated contractions. Based on hormonal serum changes it is impossible to predict the occurrence of preterm birth. This counts also for the PE ratio.

The results of a prospective, double-blind, placebo-controlled study regarding the efficacy of orally administered ritodrine after initial intravenous therapy with this drug, are described in chapter $\mathrm{V}$.

This irvestigation concerns 96 patients, sellected from the total population which had been admitted because of threatening preterm labour.

The initial therapy existed of bedrest and intravenous ritodrine. After satisfactory inhibition of uterine activity the dose of intravenous therapy was reduced and simultaneously oral therapy (ritodrine or placebo) was commenced, according to a strict protocol. In principle oral medication was continued up to the 259 th day of pregnancy or until recurrence of uterine activity forced to reinfusion.

The pregnancy-extending effect of this therapy was judged.

The following criteria were used with regard to a possible pregnancy-extending effect of this therapy:

1. the duration of oral therapy

2. the prolongation index (Richter, 1977)

3. the relative gain

It proves that oral ritodrine gives no better result than placebo treatment if the first two abowe mentioned criteria are used.

If the criterion relative gain is judged, there appears to be a positive effect towards oral ritodrine therapy in comparison with the placebo treatment. This difference is significant just below the 0.05 level $(p=0.049)$ in this investigation which has been carried out in a selected patient population. If the twin-pregnancies as well as the patients admitted in the late-premature period are excluded, the positive effect of the oral ritodrine therapy is more pronounced.

If relative gain is calculated after the moment that the influence of the initial intravenous thertpy is supposed to be neglectable, there appears to be no significant difference in the relative gain between the two groups.

It is remarkable that if the initial intravenous ritodrine therapy is replaced by oral medication (ritodrine or placebo) and secondly because of recurrence of uterine activity, reinfusion is indicated a significantly higher reinfusion dose ns necessary compared to the initial dose.

In another study the maternal rodrine serum levels are determined during the initial intravenous therapy (first treatment period), during the process of reducing the intravenous dose and simultaneously starting of oral therapy (second treatment period) and during the maintenance oral therapy (third treament period).

It seems that during the initial intravenous therapy the uterine activity levels off to zero when the serum concentration of ritodrine is between $40.50 \mathrm{ng} / \mathrm{ml}$. During the next few days (without changing the infusion rate) the ritodrine serum levels increase far above the initial therapeutical serum level.

During the reduction of the intravenous dose and switching to oral therapy (ritodrine or placebo), the slope of the ritodrine serum levels decreases more gradually in the ritodrinetreated patients in comparison with the placebo-treated patients. This may be an explanation 
for the positive effect ascribed to the oral ritodrine therapy (see chapter V) if the criterion relative gain was considered.

During oral ritodrine therapy much lower serum levels have been reached compared to intravenous therapy. These levels are about two times as low as the therapeutic levels during the initial intravenous therapy.

Besides in the course of time after the intake of medicine there prove to be strong fluctuations in the ritodrine serum levels. In this respect there is a clear relation between the ritodrine serum levels and maternal heart frequency, the maximal effect in the maternal heart frequency appearing 90 minutes after tablet-intake.

Considering the low ritodrine serum levels during oral ritodrine therapy, as well as the fluctuations in these, it is unlikely that oral-ritodrine as initial therapy for the inhibition of threatening preterm labour will be effective. 


\section{SAMENVATTING}

Het te vroeg op gang komen van de baring is de belangrijkste oorzakk van perinatale morbiditeit en mortaliteit. Tot op heden is er geen énduidige oorzaak bekend, die het to vroeg op gang komen van de baring kan verklaren. Dit wordt mede veroorzaakt door her feit dat het normale mechanisme van het op gang komen wan de baring onvoldoende opgehelderd is. In de literatuur worden voor het op gang komen van het baringsproces verschillende mechanismen aangegeven, waarop een aantal aangrijpingspunten van therapie voor premature weëenactiviteit zijn gebaseerd zoals: alcoholinfusen, betasympathicomimetica, prostaglandine synthetase remmers, calcium antagonisten en bedrust.

Ten gevolge van onvoldoende kennis van het baringsproces, is het uitermate moeilik vast te stellen of een bepaalde uterus activiteit zal leiden tot het (te vroeg) geboren worden wan het kind. In de literatuur bestaan dientengevolge grote verschillen in definities met betrekking tot het te vroeg op gang komen van de baring, met name ten aanzien van amenorrhoea en geboorte gewicht.

Hoofdstuk II geeft een overzicht van bovenstaande problematiek. Tevens wordt in dit hoofdstuk aandacht geschonken aan de veranderingen die optreden in het myometrium tijdens de zwangerschap. Uit de literatuur blijkt dat het optreden van regelmatige uterus activiteit samengaat met het ontstaan van 'gap junctions". Het optreden van deze gap junctions vindt waarschijnlijk plaats ten gevolge van hormonale veranderingen. In dit opzicht zijn vooral van belang de oestrogenen en het progesteron. Hiernatast spelen prostaglandinen en beta-sympathicomimetica een rol.

Tijdens de zwangerschap treden er veranderingen op in de serum concentraties van de verschillende stoffen die invloed hebben op o.a. de vorming van gap junctions. In dit hoofdstuk wordt de literatuur gerefereerd voor wat betreft de oestrogenen, progesteron en de onderlinge verhoudingen van deze twee hormonen. Hiernaast wordt aandacht geschonken aan corticosteroiden, oxytocine, prostaglandinen en catecholaminen. In de hedendaagse verloskunde worden de beta-sympathicomimetica het meest frequent gebruikt voor het onderdrukken van vroeglijdige weëenactiviteit. Hooldstuk III geeft een overzicht wan de farmacologische aspecten van deze stoffen zowel bij de niet-zwangeren als bij de zwangeren alsmede in het dierexperiment. Speciale aandacht wordt geschonken aan die serum spiegels van deze geneesmiddelen.

Het blijkt dat beta-sympathicomimetica in staat zijn uterus activiteit te onderdrukken. Deze eigenschap is mede afhankelijk van de structuur van de betrokken stof. Deze werking wordt waarschijnlijk geeffectueerd door in te grijpen in het adenylcyclase-cAMP mechanisme, hetgeen uiteindelijk resulteert in een verlaging wan het vrije intracellulaire calcium.

Uit een eigen onderzoek worden in hoofdstuk IV de resultaten van een longitudinaal onderzoek tijdens de zwangerschap betreffende oestradiol, oestriol en progesteron weergegeven in samenhang met de weëenactiviteit. Hiertoe werden bij 80 primigravidae tot de 37 ste week van de amenorrhoea bovengenoemde hormonen in het serum bepaald alsmede de uterus activiteit, gekwantificeerd met behulp van externe tocodynamometric. Tevens werd tegelijkertijd de weëenactiviteit kwalitatief beoordecld door de vrouw zelf te 
Haten argeven waneer ze en contractic voelde.

Het blijkt dat er een geleidelijke toename is van alle 3 genoemde homonen vijdens de zwangerschap; de spreiding is echter groot.

Er bestaat gén relatie tussen de uterus activiteit en de hormonale veranderingen in het serum. Dit geldt zowel woor de kwantitakef als kwalitatief gemeten uterus activiteit. Ook de PE ratio blijkt geen relatie te hebben met de uterus activiteit.

Fr is een slechts een geringe relatie ussen de kwantitatief gemeten uterus activiteit en het aantall contracties door de vrouw zelf subjectief ervaren.

Het is nit mogelijk om op grond vam hormonale serum concentraties een woorspelling te doen omtrent het al dan niet optreden van een wroegge

boorte. Dit geldt ook voor de PE ratio.

In hoofdstuk $V$ worden de resultaten beschreven van een prospectief, dubbel blind, placebo gecontroleerd onderzoek naar de werkzaamheid van oraal toegediend ritodrine, na initiële intraveneuze therapie met dit medicament.

Dit onderzoek heeft betrekking op 96 patienten, geselecteerd volgens een aantal criteria, uit de totale populatie die opgenomen werden wegens vroegtijdige weëenactiviteit. De initiele therapie bestond wit bedrust en intraveneus ritodrine. Wanneer de weëenactiviteit voldoende onderdrukt was, werd de intraveneuze therapie verminderd en gestart met toediening van oraal ritodrine of van placebo tabletten, volgens een in dit hoofdstuk beschreven protocol. In principe werd de orale medicatie voortgezet tot de 259 ste dag van de zwangerschap of totdat te frequente weènactiviteit intraveneuze therapie opnieuw noodzakalijk maakte.

Het effect van deze therapie in de zin van verlenging van de gravidi teit werd beoordeeld aan de hand van de volgende criteria:

1. de duur van de orate therapie,

2. de prolongatie index (Richter, 1977),

3. de relatieve winst.

Het blijkt dat orale ritodrine therapie geen beter resultaat geeft dan de placebo behandeling indion de ecrste twee van de bovengenoemde criteria worden gehanteerd.

Indien het criterium relaticwe winst wordt gebrukt, dan blijkt er een gunstig effect van de orale ritodrine therapic ten opzichte van de placebo behandeling te bestaan. Dit verschil is juist significant in dit onderzock dat uitgevoerd is in een, wit een veel grotere populatie, geselecteerde patienten groep. Indien van de onderzochte populatie de tweeling graviditeiten en de patienten met een amenor rhoea van meer dan 35 weken daremboven worden uitgesloten, wordt het gunstige effect van de orale ritodrine therapie meer uitgesproken.

Indien de relatieve winst berekend wordt op het moment dat de invloed van de initiele intraveneuze therapie verwatuloosbaar klein geacht mag worden (72 uur), blijkt er ook voor het criterium relatieve winst geen significant positief a antoonbaar effect meer te bestaan met betrekking tot do orale ritodrine therapie.

Opvallend is dat indien de initieel intravencus gestarte therapte vervangen is door orale of placebo therapie en secundair opnieuw intraveneuze therapie noodzakelijk is wegens de toegenomen uterus activiteit, er een significant hogere intraveneuze dosering nodig is in vergelijking met de initiole intraveneuze dosering. 
In een afzonderlijk onderzoek zijin de moederlijke serum spiegels van ritodrine bepaald tijdens de initiële intraveneuze therapie (first treatment period), tijdens het verlagen van de intraveneuze therapie en het tegelijkertijd instellen op orale therapie (second treatment period), alsmede tijdens orale therapie alleen (third treatment period).

Het blijkt dat tijdens de initiële intraveneuze therapie de weëen frequentie tot nul nadert bij een ritodrine serum concentratie tussen $40-50 \mathrm{ng} / \mathrm{ml}$. Bij gelijkblijvende infusiesnelheid stijgen de ritodrine serum spiegels ver boven deze initiële therapeutische grens gedurende de volgende dagen.

Tijdens het verminderen van de dosering en het gelijkertijd starten van de orale ritodrine of placebo toediening blijkt dat de ritodrine concentratie langzamer daalt bij de patienten die oraal ritodrine krijgen toegediend ten opzichte van de placebo patienten. Dit is mogelijk een verklaring voor het positieve effect dat aan de orale ritodrine therapie werd toegeschreven (zie hoofdstuk $\mathrm{V}$ ) indien het criterium relatieve winst werd gehanteerd. Tijdens orale ritodrine therapie worden veel lagere serum spiegels bereikt, vergeleken met intraveneuze therapie. Deze waarden zijn ongeveer 2 maal zo laag als de therapeutische spiegels bij de initiële intravenewze therapie.

Tevens blijken er in het verloop van de tijd nat tablet inname sterke fluctuaties in de serum spiegels voor te komen. In dit verband blijkt er een duidelijke relatie te zijn tussen de serum spiegels en de moederlijke hartfrequentie, waarbij het maximale effect in de moederlijke hartfrequentie 90 minuten na tablet inname wordt waargenomen.

Gezien de lage serum spiegels die bereikt worden tijdens orale ritodrine therapie alsmede de fluctuaties in de serum spiegels, is het onwaarschijnlijk dat initiele orale therapie voor de remming van een dreigende vroeggeboorte effectief is. 


\section{REFERENCES}

Ahlquist RP (1948)

A study of the adrenotropic receptors.

Am J Physiol : $153,586-600$

Alberman E (1974)

Stillbirth and neonatal mortally in England and Wales by birthweight 1953-71.

Health Trends: $6,14-17$

Alexandrowa M, Soloffi MS (1980)

Oxytocin Receptors and Parturition. I Control of oxytocin receptor concentration in the rat myometrium at term.

Endocrinology: $106,730-735$

Alvarez H, Caldeyro-Barcia R (1954)

The normal and abnormal contractile waves of the uterus during labour.

Gynaekologia: $138,190-212$

Anderson ABM, Lawrence KM, Turnbull AC (1969)

The relationship in anencephally between the size of the adrenal cortex and the length of gestation.

J Obstet Gynaecol Br Commonw : 76, 196-199

Anderson ABM, Lawrence KM, Daviles K, Campbell H, Turnbull AC (1971)

Fetal adrenal weight and the cause of premature delivery in human pregnancy.

J Obstet Gynaecol Br Commonw : 78, 481-488

Ariëns EJ, Simonis AM (1976)

Receptors and receptor mechanisms.

In: Beta-adrenoceptor blocking agents. Eds: Saxena PR, Forsyth RP. North-Holland Publishing

Company, Amsterdam.pp 3-27

Bakketeig LS, Hoffman HJ (1981)

Epidemiology of preterm birth: results from a longitudinal study of birth in Niorway.

In: Preterm Labour. Eds: Elder MG, Hendricks CH.

Butterworths, London.pp 17-46

\section{Barden TP (1980)}

Ritodrine hydrochloride in tocolytic therapy.

In: Tocolytic Agents. Proceedings of a symposium on tocolytic therapy. Ed: Barden TP. The society of perinatal Obstetricians, New Orleans.pp 15-29

\section{Barden TP, Peter JB, Merkatz IR (1980)}

Ritodrine hydrochloride: A betamimetic agent for use in preterm labor. 1. Pharmacology, clinical history, administration, side effects, and safety.

Obstet Gynecol : $56,1-6$

\section{Batra S (1979)}

The regulation of oestradiol and progesterone concentrations in the female reproductive tissues.

Acta Obstet Gynecol Scand,Suppl:82

Batra S (1980)

Estrogen and smooth muscle function.

TTPS : $1980,388-391$

\section{Batra S, Bengtsson LP, Grundsell H, Sjoberg N-O (1976)}

Levels of free and protein-bound progesterone in plasma during late pregnancy.

J Clin Endocrinol Metab : 42, 1041-1047

\section{Batra S, Bengtsson B (1978a)}

Effects of diethylstilboestrol and ovarian steroids on the contractile responses and calcium movements in rat uterine smooth muscle.

J Physiol (Lond): 276, 329-3442

Batra S, Bengtsson LP (1978b)

17-beta-estradiol and progesterone concentrations in myonetrium of pregnancy and their relationships to concentrations in peripheral plasma.

I Clin Endocrinol Metab : 46, 622-626 
Watra S, Bengtsson L.P, Sjoberg $\mathrm{N}=\mathrm{O}$ (1979)

Interrelations between plessma and tissue concentrations of 17 -beta-oestradiol and progesterone dering human pregnancy.

Clin Endocrinol : $11,603-610$

Baumgarten K, Grüber W (1974)

Tokolyseindex.

In: Perinatale Medizin, Band 5. Eds: Dudenhausen JW, Saling E Thieme, Stuttgart.pp : $58-59$

Baumgarten $K$, Lingard W, Horvat $A$, Chalkitis $J$, Cerwenka $R$, Hellmich C (1982)

Uber die Werksamkeit oral applizierter Beta mimetika am oxytocinstimulierten puerperalen Modell.

Geburtshilfe Fratenheilkd: 42, 103-114

\section{Benedetti $\mathrm{rJ}(1983)$}

Matemal complications of parenteral belta-sympathomimetic therapy for premature labor.

An J Obsten Gynecol: $145,1 \cdots 6$

Berg G, Andersson RGG, Ryden G (1982)

Effects of selective beta-adrenergic agonists on spontaneous contractions. CAMP levels and phosphodiesterase activity in myometrial strips from pregnant women treated with terbutaline.

Oynecol Obstet lravest : $14,56-64$

Biblby JG, Higgs SA, Kent AP, Flint APF, Mitchell MD, Anderson ABM, Turnbull AC (1978)

Plasma scroid changes in preterm labour in association with salbutamol infusion.

Br J Otwitet Gynaecol : $85,425 \times 430$

Bishop EH, Wouterz TB (1961)

Arresil of premature labor.

JAMA: $178,812-814$

Bishop, EH (1964)

Pelvic scoring for elective induction

Obstel Gynceol : $24,266-268$

Bowman WC, Rand MJ, West GB (1968)

Textbook of Pharmacology.

Blackwell Scientific Publications, Oxford

Brazy JE, Pupkin M. (1979)

Effects of maternal isoxsuprine administration on preterm infants.

J Pediatr: : $94,444-448$

\section{Brazy JE, Little V, Grimm Jl (1981)}

Isoxsuprine in the perinatal period. II. Relationships between neonatal symptoms, drug exposure, stnd drugeoncentrations at the time of birth.

I Pediatr: $98,146-151$

Mremme K, Eneroth P (1981)

Senum Fstriol levels during beta-receptor agonist infusion in the thidd irimester of pregnancy.

Gynecol Obstet lnvest : $12,93-98$

Uisehelt $L_{4}$, Rominger KL. (1972)

Pharmakokinetik und Metabolismus von Th 1 1 65 a heim Menschen.

Tnt IClin Pharmacol Betheft 4 Berolcepp : $37-41$

Muster JE (19.980)

Fotal adrenal cortex.

Chin Obstet Gynecol : $23,803-823$

Caritis SN, Edelstone DI, Mueller-Heubach E (1979)

Pharmacologic inhibition of preterm labor.

An J Obstet Gynecol : 133,557-578

Carpenter RJ (1982)

Preterm labor: cause and managenent.

Coniper Ther: $8,37-46$

\section{Carlsson E, Ablad B (1976)}

Are there two types of beta-receptors mediating the same adrenergic reponse?

In: Beta-adrenoceptor blocking agents. Eds: Saxena PR, Forsyth RP. North-Holland Publishing

Company, Amsterdam.pp : 305-309 
Carsten ME (1979)

Calcium accumulation by human uterine microsomal preparations : Effect of progesterone and oxytocin.

Am J Obstet Gynecol : 133, 598-601

Cetrulo CL, Freeman RK (1976)

Ritodrine HCL for the prevention of premature labor in twin pregnancies.

Acta Genet Med Gemellol : 25, 321-324

Chard T (1973)

The role of the posterior pituitaries of mother and foetus in spontaneous parturition.

In: Foetal and Neonatal Physiology. Eds: Comline KS, Cross KW, Dawes GS. Cambridge University

Press, Cambridge.pp : $579-583$

Cohen SL (1976)

Estrogens and pregnancy.

In: Perinatal Medicine. Eds: Goodwin JW, Godden JO, Chance GW. Willians and Willkins,

Baltimore.pp : 363.382

Compton AA, Kirkish LS, Parra JB, Stoecklein S, Barclay ML, McCann DS (1979)

Diurnal variations in unconjugated and total plasma estriol levels in late normal pregnancy.

Obstet Gynecol : $53,623-626$

Cousins LM, Hobel CJ, Chang RJ, Okada DM, Marshall JR (1977)

Serum progesterone and estradiol-17-beta levels in premature and term labor.

Am J Obstet Gynecol : 127,612-615

Creasy RK, Golbus MS, Laros RK, Parer JT, Roberts JM (1980)

Oral ritodrine maintenance in the treatment of preterm labor.

Am J Obster Gynecol : 137, 212-219

Creasy RK, Gummer BA, Liggins GC (1980)

System for predicting spontaneous preterm birth.

Obstet Gynecol : $55,692-695$

Csapo AI (1956)

The mechanism of effect of the ovarian steroids.

Recent Prog Horm Res : 12, 404-431

Csapo AI (1975)

The "Seesaw" theory of the regulatory mechanism of pregnancy.

Am J Obstet Gynecol : $121,578-581$

Csnpo AI, Knobil E, wd Molen HJ, Wiest WG (1971)

Peripheral plasma progesterone levels during human pregnancy and labor.

Am J Obstet Gynecol : 110, 630-632

Csapo AI, Csapo EF, Fay E, Henzl MR, Salau G (1973)

The role of estradiol 17 -beta in the activation of the uterus cturing premature labor and the effect of naproxen, an inhibitor of prostaglandin synthesis.

Prostaglandins : $3,839-846$

Csapo AI, Pohanka O, Kaihola HL, (1974)

Progesterone deficiency and premature labour.

Br Med J : 1, 137-140

Csapo AI, Herczeg J (1977)

Arrest of premature labor by isoxsuprine.

Am J Obstet Gynecol : $129,482-491$

Daniel EE, Lodge S (1972)

Electrophysiology of myometrium.

In: Uterime Contraction - Side effects of steroidal contraceptives. Edi: Josimovich JB. John Wiltey and

Sons, New York. pp 19-64

Dawies PA (1976)

Outlook for the low birthweight baby - then and now.

Arch Dis Child : $51,817-819$ 
Dawoud MY, Raghavan KS, Poelask C $\mathrm{C}_{\text {, Fuchs }}$ (1978)

Oxylocin in human pregnancy and parturition.

Obstet Gynecoll : $51,138-143$

Desir D, wan Coevorden A, Kirkpattick C, Caufrlez A (1978)

Ritodrine-induced acidosis in pregnancy.

BrMed J: 2, 1194

Driel C van, Houthof HJ, Baljet B (1973)

The innervation of the myometrium. Some histochemical observations in man and rat.

Eur $\mathbb{J}$ Obstet Gynecol Reprod Biol : 3, 11-17

Eadie MJ, Lander CM, Tyrer JH (1977)

Plasma drug level monitoring in pregnancy.

Clin Pharmacokinet : $2,427-436$

Epstein MF, Nicholls $E_{*}$ Stublblefteld PG (1979)

Neonatal bypoglycemia after beta-sympathomimetic tocolytic therapy.

J Pediatr: $94,449-453$

Erickson JD, Bjerkedall T (1978)

Interpregnancy interval.

J Epidemiol Community Health : $32,124-130$

\section{Eskes TKAB, Essed GGM (1979)}

Inhibition of uterine contractility with beta-mimetic drugs.

In: Human parturition. Eds: Keirse MJNC, Anderson ABM, Bennebroek Gravenhorst J. Leiden

Uniwersity Press, The Hague.pp 165-187

\section{Essed GGM (1981)}

Aspects of human tocolysis with adrenergic agents.

Thesis, Nijmegen.

Falck Larsen J, Kern Hansen M, Hessendahl H (1980)

Ritodrine in the treatment of preterm labour. A clinical trial to compare a standard treatment with three regimens involving the use of ritodrine.

Br J Obstet Gynaecol : 87, 949-957

Falkay G, Herczeg J, Kovács L, (1978)

Effect of betamimetic isoxsuprine on prostaglandin biosynthesis in pregnant human myometrium in vitro.

Life Sci : $23,2689-2696$

\section{Fedrick J, Anderson ABM (1976)}

Factors associated with spontaneous pre-term birth.

Br. J Obstet Oynaecol : $83,342-350$

Felchtinger $W$, Altman G (1981)

Rheobase, $P_{\mathrm{e}}$ : lvic Score und Oxytocinempfindlichkeitstest vor spontanem Geburtsbeginn.

Z Geburtshilfe Perinatal : 185, , 41 1-143

Ferre $F$, Janssens $Y$, Tanguy $G$, Breuiller $M$, de Pariente $\mathbb{D}$, Cedard $L$ (1978)

Steroid concentrations in human myometrium and placental tissues at week 39 of pregnancy.

Am J Obstet Gynecol: 131, 500-502

Flint APF (1979)

Role of progesterone and oestrogens in the control of the onset of labour in man : A continuing controversy.

In: Human Parturition. Eds: Keirse MJNC, Anderson ABM. Bennebroek Gravenhorst J. Leiden

University Press, "The Hague.pp : 85-100

\section{Fuchs F (1976)}

Prevention of prematurity.

An J Obstet Gynecol: 126, 809-820

\section{Fuchs F (1977)}

Endocrinology of labor.

In: Endocrinology of pregnancy. Eds: Fuchs F, Klopper A. Harper and Row, Hagerstown.pp 327-349 
Fuchs F, Klopper A (1977)

Endiocrinology of pregnancy.

Harper and Row, Hagerstown.

Gandar R, de Zoeten LW, van der Schoot JB (1980)

Serum level of ritodrine in man.

Eur I Clin Pharmacol : 17, 117-122

Garfield RE, Sims SM, Kannan MS, Daniel EE (1978)

Possible role of gap junctions in activation of myometrium during parturition.

Am J Physiol : 235, C168-C179

Garfield RE, Rabideau S, Challis JRG, Daniel EE (1979)

Ultrastructural basis for maintenance and termination of pregnancy.

Am J Obstet Gynecol : $133,308-315$

Garfield RE, Kannan MS, Daniel EE (1980a)

Gap junction formation in myonetritm : control by estrogens, progesterone and prostaglandins.

Am J Physiol : 238, C81-C89

Garfield RE, Merrett D, Grower AK (1980b)

Gap junction formation and regulation in myometrium.

Am J Physiol : $239, \mathrm{C} 217 \cdot \mathrm{C} 228$

Garfield RE, Hayashi RH (1981)

Appearance of gap junctions in the myometrium of women during labor.

Am J Obstet Gynecol 140:254-260

\section{Geldorp van $H J(1980)$}

Electromyografie wan de niet-zwangere uterus.

Thesis, Rotterdam

Goodmann LS, Gillman A (1975)

The pharmacological basis of therapeutics.

McMillan, New York.

Grand RJA, Perry SV (1978)

The amino acid sequence of the troponin C-like protein (modulator protein) from bovine uterus. FEBS lett : 92-137-142

Grieves SA, Liggins GC (1976)

Phospholipase A activity in human and ovine uterine tissues.

Prostaglandins : $12,229-241$

de Haan J, Thomas CMG, Jongsma HW, Arts THM, Eskes TKAB (1978)

Placental transfer of tritium labelled Th 1165 -a (Partusistent) in Rhesus monkeys.

In: Perinatale Medizin, Band VII. Eds: Schmidt E, Dudenhausen JW, Saling. E. Thieme, Stutgart.pp $: 147-148$

Harbon S, Tanfin-Toughi Z, Dohkac L. (11982)

Modulation of CAMP content of the rat myometrium: Beta-adrenergic-and PGE2-induced stimulation

and desensitization.

Brussels.

\section{Haukkamaa M, Lätheenmäki P'(1979)}

Steroids in human myometrium and maternal and umbilical cord plasma before and during labor.

Obstet Gynecol : 53, 617-622

Haukkamaa M, Gummerus M (1982)

Decrease of serum oestriol during intravenous hexoprenaline or salbutamol treatment.

Bir J Obstet Gynaecol : $89,917-920$

Hemminki E, Starfield B (1978)

Prevention and treatment of premature labour by drugs: Review of controlled clinicall trials.

Br J Obstet Gynaecoll: $85,411-417$

Hendricks CH, Cibils LA, Pose SV, Eskes TKAB (1961)

The pharmacologic control of excessive uterine activity with isoxsuprine.

Am J Obstet Gynecol : 82, 1064-1078 
Herron MA, Katz M, Creasy RK (1982)

Evaluation of a preterm birth prevention program: preliminary report.

Obstet Gynecol: $59,452-456$

Hillary FK, Cohen SL (1981)

The changing estrogen content of the nucleat fraction of human myometrium during labor.

Steroids: $38,175-184$

\section{Honnebier Wil, Swaab DF (1973)}

The influence of anencephaly upon intra-uterine growth of the fetus and placenta and upon gestation length.

J Obstet Gynaecol Br Commonw: $80,577-588$

Husslein P, Fuchs AR, Soloff MS, Fuchs F (1982)

Initiert fetales Oxytozin den Geburtsbeginn beim Menschen? Eine Hypothese.

Geburtshilfe Frauerheilkd : $42,579-582$

\section{Huszar G (1980)}

Current concepts of myometrial Control.

In: Tocolytic Agents, Proceedings of a symposium on Tocolytic Therap. Ed: Barden TP. The society of perinatal Obstetricians, New Orleans.pp: 1-14

\section{Huszar G, Roherts JM (1982)}

Biochemistry and pharmacology of the myometrium and labor: regulation at the cellular and molecular levels.

Am J Obstet Gynecol : 142, 225-237

\section{Ingemarsson J (1976)}

Effect of terbutaline on premature labor. A double-blind placebo controlled study.

Am J Obstet Gynecol : $125,520-524$

Joliwet A, Blanchier H, Gautray JP (1974)

Blood cortisol variations during late pregnancy and labor.

Am I Obstet Gynecol : 119, 775-783

\section{Josimovich JB (1972)}

Uterine contraction - Side effects of steroidal contraceptives.

In: Problems of human reproduction. Ed: Josimovich JB. John Wiley and Sons, New York, London, Sydney, Toronto.

\section{Jung H, Abramowski P, Kiőck FK, Schwenzel W (1971)}

Zur Wirkung alfa- und betm-adrenergischer Substanzen am menschlichen Uterus und Nebenwirkungen æuf Mutter und Kind.

Geburtshilfe Frauenheilkd : 31, 11-27

\section{Jung H (1981)}

Ursachen des Geburtseintritts.

In: Gynakologie und Geburtshilfe, Bd II/2. Eds: w Kăser O, Friedberg V, Ober KG, Thomsen K, Zander J, Thieme, Stuttgart pp 516-521

Kaltreider DF, Kohl $S$ (1980)

Epidemiology of preterm delivery.

Clin Obstet Gynecol : $23,17-31$

\section{Kanhai HHH (1981)}

Achtergronden en konsekwenties van wroeggeboorte.

Thesis, Leiden

\section{Katagiri H, Distler W, Freeman RK, Goebelsmann U (1975)}

Estriol in pregnancy. IV. Normal concentrations, diurnal and/or episodic variations, and day-to-day changes of unconjugated and total estriol in late pregmancy plasma.

Am J Obstet Gynecol : $121,272-280$

\section{Kauppila A, Hartikainen-Sorri AL, Jänne O, Tü̈male R, Järvinen PA (1980)}

Suppression of threatened premature labor by administration of cortisol and 17 alpha-hydroxy progesterone caproate: A comparison with ritodrine.

Am J' Obstet Gynecol : 138, 404-408

\section{Keirse MJNC (1979)}

Endogenous prostaglandins in human parturition. In: Human Parturition. Eds: Keirse MJNC, Anderson ABM, Bennebroek Gravenhorst J. Leiden University Press, The Hague .pp : 101-142 
Keirse MJNC Anderson ABM, Bennebroek Gravenhorst J (1979)

Human parturition. Leiden Unversity Press, The Hague.

Keirse MJNC, Thiery M, Parewijck W, Mitchell MD (11983)

Chronic stimulation of uterine prostaglandin synthesis during cervical ripening before the onset of labor.

Prostaglandins : $25,671-682$

\section{Kelly JV (1961)}

The effect of intravenous estrogens on uterine motility.

Am J Obster Gynecol: $82,1207-1210$

Klaus MH, Fanaroff AA (1978)

Das Risiko-Nengeborene.

Gustav Fisher, Stuttgart

Kleinhout J, Veth AFL (1975)

Placental transfer of ritodrine and its effect on the fetal car diovascular system.

In: Aspects of Obstetrics Today. Eds: Eskes TKAB, Haan I de, Kessel H wan. Excerpta Medica, Amsterdam.pp : $385-390$

Klöck FK (1977)

The action of sympathomimetic drugs on uterine muscle

In: Labour inhibiton. Betamimetic drugs in obstetrics, Ed: Weidinger H. Gustav Fischer, Stuttgart pp $: 27-39$

\section{Kloosterman G.J (1977)}

Abnormale duur van de zwangerschap.

In: De voortplanting van de mers. Ed: Kloosterman GJ. Centen, Haarlem.pp: $332-342$

Koepcke E, Herrmann Ch, Seidenschnur G (1976)

Ambulante Tokographie.

Zbl Gynäk : $98,1281-1286$

Kords H (1977)

Pharmacology and pharmacokinetics of partusisten (Fenoterol).

In: Labour inhibition. Betamimetic drugs in obstetrics. Ed: Weidinger H. Gustav Fischer, Stutgart.pp: $41-46$

Kubli F (1977)

Beta-adrenergic agonists.

In: Pre-term labour. Eds: Anderson A, Beard R, Brudenell JM, Dunn PM. Royal College of Obstetricians and Gynaecologists. London.pp : $218-220$

Kubli F, Rüttgers H, Schenk D (1977)

Prevention of premature labour.

In: Labour Inhibition. Betamimetic drugs in obstetrics.

Ed: Weidinger H. Gustav Wischer, Stutrgart.pp: 177-183

L.ands AM, Arnold A, McAulif JP, Luduena FP, Arown TG (1967a)

Differentiation of receptor systems activated by sympathomimetic amines.

Nature: $214,597-598$

Lands AM, Luduena FP, Buzzo HJ (1967b)

Differentiation of receptors responsive to isoproterenol.

Life Sci : $6,2241-2249$

Larsen JW, Hanson TM, Caldwell BV, Speroff L, (1973)

The effect of oestradiol infusion on uterine activity and peripheral levels of prostaglandin $F$ and progesterone.

Am J Obstet Gynecol : 117, 276-279

Lauersen NH, Merkatz IR, Tejani N, Wilson KH, Robertson A, Marn LA, Fuchs F (1977)

Inhibition of premature labor: A multicentre comparison of rito

drine and ethanol.

Am J Obstet Gynecol : $127,837-845$ 
Leeuwen yan M, Boeles JTF, Wolfs GMJA (1979)

Some physiological aspects of uterine contractility in man.

In: Human pathurition. Eds: Keirse MJNC, Anderson ABM, Bennebroek Gravenhorst J. Leiden

University Press, The Hague.pp: : $11-48$

Leferink JG, Wagernaker-Engels I, Maes RAA (1977)

Quantitative analysis of terbutaline in serum and urine at therapeutic levels using gaschromotography - mass spectrometry.

J Chromatogr: $143,299-305$

Lemaire WJ, Conley PW, Mofrett A, Cleveland WW (1970)

Plasma progesteronit secretion by the corpus luteum of term pregnancy.

Am J Obstet Gynecol: 1018, 132-134

van Lierde $M$, Valembois B, Leonard P, Vankrieken $L$, Brulet $C$, Thomas $K$ (1981)

Réponse des récepteurs bèta-adrénergiques en fonction du taux plasmatique de ritodrine et du mode d"administration.

Médicine Périnatâle: $1981,386-394$

van Lierde M, Thomas K (1982)

Ritodrine concentrations in maternal and fetal serums and amniotic fluid.

J Perinat Med : $10,119 \times 124$

Liggins GC, Fairclaugh RJ, Grieves SA, Kendall JZ, Knox BS (1973)

The mechanism of initiation of parturation in the ewe.

Recent Prog Horm Res : 29, 111-150

Liggins GC (1976)

Adrenocortical-related maturational events in the fetus.

Am J Obstet Gynecol : 126, $931-941$

Lindberg BS, Nilsson BA, Johansson EDB (1974)

Plasma progesterone levels in normal and abnormal pregnancies.

Acta Obstet Gynecol Scand : 53, 329-335

Lish PM, Hillyard IW, Dungan KW (1960)

The uterine relaxant properties of isoxsuprine.

I Pharmacoll Exp Ther : 129, $438-444$

Martin LE, Rees I, Tanner R.J (1976)

Ouantitative determination of salbutamol in plasma, as either its trimethylsilyl or to-butyldimethylsilyl ether, using a stable isotope multiple ion recording Technique.

Biomed Mass Spectom : 3, 184-190)

Martimsen K, Peltola J, Tervilä L, Virtanen A (1982)

Umbitical Cord Cortisol and arterial pH levels in spontaneous and induced labors.

Obstet Gynecol : $59,171 \cdot 175$

Masson GM, Wilson GR (1971)

Variability of total plasma oestriol in late human pregnancy.

J Endoctinol : $54,245-250$

Mathur RS, Landgrebe S, Williamson HO (1980)

Progesterone, 17-hydroxyprogesteron, estradiol, and estriol in late pregnancy and labor.

Am J Obster Gynecol: : 136, 25-27

McGill R, Tukey JW, Larsen WA (1978)

Variations of Box plots.

Am Stat: $32,12-16$

Miller JM, Keane MWD, Horger EO (1982)

A comparison of magnesium sulfate and terbutaline for the arrest of premature labor.

J Reprod Med : 27, 348-351

Milliex J, Bhot P, Sureau C (1980)

A case report of maternal death associated with betamimetics and betamethasone administration in premature labor.

Eur J Obstet Gynecol Biol Reprod : 11, 95-100 
Mitchell MD (1979)

Parturition in Sheep.

In: Human parturition. Eds: Keirse MINC, Anderson ABM, Bennebroek Gravenhorst J. Leiden

University Press, The Haguepp : $11-23$

Miyakawa I, Ikeda I, Maeyama M (1974)

Tramsport of ACTH across human placenta.

J Clin Endocrinol Metab : 39, 440-442

Mossman RG, Conrad JT (1967)

In vitro blocking and oxytocic effects of water-soluble estrogens on pregnant human, mouse and rat uteri.

Am J Obstet Gynecol : 99, 539-545

Murphy BEP (1973)

Does the human fetal adrenal play a role in parturition?

Am I Obstet Gynecol : 115, 521-525

Murphy BEP (1981)

Demonstration of novel compounds in human fetal tissues and a consideration of their possible role in parturition.

Am J Obstet Gynecol : 139, 353-358

Naylor G, Poyser NL (1975)

Effects of oestradiol and progesterone on the in vitro production of prostaglandin $F_{2}$ by the guinea-pig uterus.

BrJPharmacol : 55, 229

Newton RW, Webster PAC, Binu PS, Maskrey N, Phillips AB (1979)

Psychosocial stress in pregnancy and its relation to the onset of premature labour.

Br med J : 2, 411-413

Nilsson HT, Persson K, Tegnér K (1972)

The metabolism of terbutaline in man.

Xenobiotica : 2, 363-375

Nishikori K, Maeno H (1979)

Close relationship between adenosine 3' 5 '-monophosphate - dependent endogenous phosphorylation of a specific protein and stimulation of calcium uptake in rat uterine microsomes.

J Biol Chem : 254, 6099-6106

O'Connor MC, Murphy H, Dalry mple IJ (1979)

Double blind trial of ritodrine and placebo in twin pregnancy.

Br J Obstet Gynaecol : 86, 706-709

Okazaki T, Casey MR, Okitz JR, MacDonald PC, Johnston JM (1981)

Initiation of human parturition. XII Biosynthesis and metabolism of prostaglandins in human fetal membranes and uterine decidua.

Am J Obstet Gynecol : 139, 373-381

Osa T (1971)

Effect of removing the external sodium on the electrial and mechanical activities of the pregnant mouse myometrium.

Jpa I Physiol : 21, 607

Parker CR, Everett RB, Quirk JG, Whalley PJ, Gant NF (1979)

Hormone production during pregnancy in the primigravid patiemt. I. Plasma levels of progesterone and 5 alpha-pregnane-3,20-dione throughout pregnancy of normal women and women who developed pregnancy-induced hypertension.

Am J Obstet Gynecol : 135, 778-782

Parlati E, Dell'Acque S, Cinque B, Trayaglini R, Navarretta V, Maniccia E, Bomplani A (1982)

Endocrine factors involved in the mechanism of labor in humans.

Paper presented at the 6th F.R.E.S.E.R.H. International symposium "Uterine Contractility", Brussels

\section{Philips DK (1980)}

Chemistry of alpha- and beta-adrenoceptor agonists and antagonists.

In: Adrenergic Activators and Inhibitors, Vol 54, Part 1. Handbook of Experimental Pharmacology.

Ed: Szekeres L. Springer, Berlin. pp : 3-17 
Minto RM, Leon C, Mazzocto N, Scasserra V (1967)

Action of oestradiol-17-beta at term and at onset of labor.

Am I Obstet Gynecol: $98,540-546$

Pokolly TB (1973)

The role of cortisol in thuman parturition.

Am It Obstet Gynecol : 117, 549-553

Past LC (1977)

Pharmacokinetics of beta-adrenergic agonists.

In: Pre-term labour. Eds: Anderson A, Beard R, Brudenell IM, Dunn PM. The Royal College of Obstetricians and Gynaecologists, London. pp : 134-148

\section{Pritchard JA, MacDonald PC (1976)}

Physiology of labor.

In: Obstetrics. Williams. Eds: Pritchard JA, MacDonald: PC.

Appleton-Century, New York.pp : 294-313

Pwolakka I, Kauppila A, Tuimalla R, Pakarinen A (1982)

Fetal adrenocorticotropic hormone and prolactin at delivery.

Obstet Gynecol: $60,71-73$

Rasmussen $\mathrm{H}$, Tenenhouse A (1968)

Cyclic adenosine monophosphate, $\mathrm{Ca}$ ** and membranes.

Proc Natl Acad Sci USA : 59, 1364-1370

Ray mond LW, Sode J, Tuccl JR (1972)

Adrenocorticol response to non-exhaustive muscular exercise.

Acta Endocrinol : 70, 73-80

Reynolds SRM (1931)

Studies on uterus.

Am J Physiol : 97, 706-721

Richter, $\mathbf{R}(1977)$

Evaluation of success in treatment of threatening premature labor by betamimetic drugs.

Am J Obstet Gynecol: $127,482-486$

Ritchie K, MeClure G (1979)

Prematurity.

Lancet $2: 1227-1229$

Roberts JM, Insel PA, Goldfien RD, Goldfien A (1977)

Alphadrenoreceptors but not beta adrenoreceptors increase in rabit uterus with estrogen.

Nature: $270,624-625$

\section{Roberts JS (11975)}

Cyclical fluctuations in reflexive oxytocin release during the estrous cycle of the goat.

Biol Reprod: $13,314.317$

Robinson GA, Butcher RW, Sutherland EW (1971)

Cyclic AMP.

Academic Press, New York

Rominger KL (1977)

Zur Pharmakokinetik von Partusisten.

In: Fenoterol (Partusisten) bei der Behandlung in der Geburtshilfe und Perinatologie. Eds: Jung H, Friedrich E. Thiome, Stuttgart. pp : 15-20

Rose LI, Friedman HS, Beering SC, Cooper KH (1970)

Plisma cortisol changes following a mile run in conditioned subjects.

J Clin Endocrinol: $31,339-341$

Rucker MP (1925)

The action of adrenaline on the pregnant human uterus.

South Med J : 18,412

Rush RW, Keirse MJNC, Howat P, Baum JD, Anderson ABM, Turmbull AC (1976)

Contribution of preterm delivery to perinatal mortality.

Br Med J : 2, 965-968 
Rush RW, Davey DA, Segall ML (1978)

The effect of preterm delivery on perinatal mortality.

Br J Obstet Gynaecol : 85, 806-811.

Sas M, Kovéces L (1980)

Systemic pharmacology of adrenergic activators and inhibitors: Eiffects on genital system.

In: Adrenergic Activators and Inhibitors, Vol 54, Part II, Handbook of experimental Phamrnacology.

Ed: Szekeres $\mathbb{L}$. Springer, Berlin.pp : $213-242$

Schwarz BE, Schultz FM, MacDonald PC, Johnston JM (1975)

Initiation of human parturition III. Fetal membrane content of prostaglandin E2 and $\mathrm{F} 2$ precursor.

Obstet Gyneool : $46,564-568$

Sellers SM, Hodgson HT, Mountford LA, Mitchell MD, Anderson ABM, Turnbull AC (1981)

Is oxytocin involved in parturition?

Br J Obster Gynaecol: $88,725-729$

Shaaban MM, Klopper A (1973)

Changes in unconjugated oestrogens and progesterone concentration in plasma at the approach of labour.

J Obstet Gynaecol Br Commonw: $80,210-217$

Siteri PK, MacDonald PC (1966)

Placental estrogen biosynthesis during buman pregnancy.

$\checkmark$ Clin Endacrinol : $26,75 \rrbracket-761$

Siiteri PK, Febres F, Chang RJ, Clemens LE, Gondos B (1976)

Immunosuppressive properties of progesterone.

58 th Annual Meeting of the endocrine society: 1976, Abstract 247

Sims CD, Chamberlain GVP, Boyd IE, Lewis PI (1978)

A comparison of salbumatol and ethanol in the treatment of preterm labour.

Br J Obstet Gynaecol : 85, 761-766

Sivasambon R (1972)

Premature labour.

In: Proceedings of the international symposium on the treat ment of foetal risks. Eds: Baumgarten $K$, Wesselius-de Camparis A. University of Vienna, Vienna.pp: 16-20

Soloff MS (1979)

Regulation of oxytocin action at the receptor level.

Life Sci : $25,1453-1460$

Soloff MS, Alexandrova M, Fernstrom MJ (1979)

Oxytocin Receptors: Triggers for parturition and lactation?

Science : $204,1313 \cdot 1315$

Spellacy WN, Cruz AC, Birk SA, Buhi WC (1979)

Treatment of premature labor with ritodrine: A randomized con

trolled study.

Obstet Gynecol : 54, 220-223

Speroff L, Glass H, Kase NG (1978)

Clinical gynecologic endocrinology and infertility. Williams and Wilkins Co, Baltimote.

Speroff L, Glass RH, Kase NG (1978)

The Endocrinology of pregnancy.

in: Clinical gynecologic endocrinology and infertility. Eds: Speroff L, Glass RH, Kase NG. Williams and Wilkins Co, Baltimore.

$p p: 185-230$

Stander RW, Barden TP (1970)

Influence of steroids on human myometrial contractility and myometrial response to catecholamines

Am I Obstet Gynecol : 108, 795-804

Stewart A (1981)

Perinatal morbidity in preterm infant: causes, consequences and prevention.

In: Aspects of perinatal morbidity. Ed: Huisjes HJ. Universitaire Boekhandel Nederland,

Groningen pp : $36-53$ 
Stewart A, Turcan DM, Rawlings G, Reynolds EOR (1977)

Prognosis for infants weighing $1000 \mathrm{~g}$ ar less at birth.

Arch Dis Child: $52,97-104$

Sutherland EW, Rall TW (1960)

Relation of adrenosine $35^{\circ}$-phosphate and phosphorylase to the actions of catocholamines and other hormones.

Pharmacol Rev: 12, 265

Sybulski S, Maughan GR (1976A)

Cortisol lewels in umbilical cord plasma in relation to labor and deliwery.

Am J Obstet Gynecol: $125,236-238$

\section{Sylbulski S, Maughan GB (1976B)}

Relationship between cortisoll levels in umbilical cord plasma and development of the respiratory distress syndrome in premature newborn infants.

Am J Obstet Gynecol: $125,239-243$

Takahashi K, Diamond F, Bieniarz J, Yen H, Burd L (1980)

Uterine contractility and oxytocin sensitivity in preterm, term and postterm pregnancy.

Am J Obstet Gynecol : 136,774-779

Talbert LM, Easterling WE, Potter HD (1973)

Maternal and fetal plasma levels of adrenal corticoids in spontaneous waginal delivery and cesarean section.

A.m J Obstet Gynecol : 117, 554-559

Tamby Raja RL, Anderson ABM, Turnbull AC (1974)

Endocrine changes in premature labor.

Br Med $J: 4,67-71$

Thomas K, Vankrieken L, van Lierde M (1982)

Characterization of ritodrine radioimmunoassay.

Gynecoll Obstet Invest : 14, 151- 155

Thorburn GD, Challis JRG (1979)

Endocrine control of parturition.

Physiol Rev : $59,863-917$

Tukey JW (1977)

Exploratory data analysis.

Addison - Wesley

Tulchinsky D, Hobel CJ, Yeager E, Marshall JR (1972)

Plasma estrone, estradiol, estriol, progesterone and 17-hydroxy progesterone in human pregnancy. Am J Obstet Gynecol : 112, 1095-1100

Turnbull AC, Flinf APF, Jeremy JY, Patten PT, Keirse MINC, Anderson ABM (1974)

Significant fall in progesterone and rise in oestradioll hevels in human peripheral plasma before onset of labour.

Lancet : $1974,101-103$

Vasicka A, Kumaresan P, Han GS, Kumaresan M (1978)

Plasma oxytocin in initiation of labor.

An J Obstet Gynecol : 130, 263.273

Walters WAW, Wood C (1977)

A trial of oral ritodrine for the prevention of premature labour.

Br J Obstet Gynaecol: $84,26-30$

Wesselius-de Casparis A, Thiery M, Yo Le Sian A, Baumgarten K, Brosens I, Gamisans O, Stolk JG, Vivier W (1971)

Results of double-blind, multicentre study with ritodrine in premature labour.

Br Med J : 3, 144-147

White $\mathbb{P}$ (1978)

Classification of obstetric diabetes.

Ant J Obstet Gynecol : 130, 228-230 
WHO (1977)

Recommended definitions, terminology and format for statistical tables related to the perinatal period and use of a new certificate for cause of perinatal deaths.

Acta Obstet Gynecol Scand: $56,247-253$

Winter R, Weiss PAM (1979)

Mehrlingsschwangerschaft und prophylaktische Tokolyse mit Ritodrine.

Arch Gynäkol : 228, 158-159

Yagi K, Yazawa M, Kakiuchi S, Ohshima M, Uenishi K (1978)

Identification of an activator protein for myosine light chain kinase as the $\mathrm{Ca}^{2 \mathbf{H}}$-dependant modulator protein.

J Biol Chem : $253,1338-1340$

\section{Zahn V (1978)}

Physiologie der Uteruskontraktionen.

Z Geburtshilfe Perinatol : $182,263-268$

Zerbe GO, Walker $\mathrm{S}$ (1977)

A randomization test for comparison of groups of growth curves with different polynomial design matrices.

Brometrics: $33,653-657$

\section{Zuspan FP (1970)}

Urinary excretion of epinephrine and norepinephrine during pregnancy

J Clin Endocrinol : $30,357-360$ 


\section{Definitions and abbreviations used in this thesis}

Duration of amenorrhoea The time period after the first day of the last nomal menstrual period, expressed in completed days or completed weaks.

Gestational age

The duration of gestation as measured from the first day of the last menstrual period expressed in completed days of completed weeks.

Abortion

Preterm

Term

Postterm

Perinatal period

False labour

Threatening preterm labour

Early neonatal death

Late neonatal death
The expulsion or extraction of a product of conception before the 16 th completed week of gestational age.

Less than 37 completed weeks of gestational age.

From 37 completed weeks to less than 42 completed weeks of gestational age.

42 or more completed weeks of gestational age.

Period between 28 completed weeks of gestational age and the end of the seventh completed day after delivery.

Uterine contractility which, untreated, does not result in effacement and/or dilatation of the cervix.

Uterine activity in the preterm period, forcing to tocolytic therapy. (Because of this intervention, no judgennent is given as to whether true labour or false labour was present).

Death of a live-born infant within the first seven completed days of life.

Death of a live-born infant after seven completed days but before 28 completed days of life. 
$E$

$E_{2}$

Es

$\mathrm{E}_{3} \mathbb{F}_{2}$ ratio

P

PE ratio

PE, ratio

$\mathrm{PE}_{3}$ ratio

$P G$
Oestrone

17 -beta-oestradiol.

Oestriol.

Oestriol-Oestradiol ratio.

Progesterone.

Progesterone-Oestrogen ratio.

Progesterone-Oestradiol ratio.

Progesterone-Oestriol ratio.

Prostaglandin. 


\section{SLOTWOORD}

Dit slotwoord geeft mij de gelegenheid on diegenen te danken die onmisbaar bleken bij het tot stand komen van dit proefschrift.

Het in dit proefschrift beschreven onderzoek werd witgevoerd in de kliniek voor Obstetrie en Gynaecologie van de Rijksuniversiteit Limburg (Hoofd Prof.Dr. J. de Haan), met medewerking van Duphar Nederland BV.

Hooggeleerde de Haan, geachte promotor en opleider, in korte tijd creèerde je een afdeling, warin het mogelijk bleek klinisch en wetenschappelijk werk te combineren. Jouw prikkelende opmerkingen hebben wisselend be- en ontmoedigend gewerkt. Dat dit boekje klaar kwam, bewijst dat je benadering niet de slechtste was.

Zeergeleerde Essed, beste Gerard, jouw inzicht in de materie en jouw zorg voor details hebben in grote mate ertoe geleid dat het proefschrift verschenen is, zoals het nu voor je ligt.

Hooggeleerde Keirse, de bereidheid om de resultaten van een door U geinitieerd en uitgevoerd onderzoek in een later stadium te publiceren en de zorgvuldigheid waarmee U het concept van dit proefschrift corrigeerde, zou ik grag typisch Leids willen noemen. Hooggeleercle Struyker Boudier, Uw adviezen betreffende de pharmacologische aspecten en de snelheid warmee $U$ het concept nakeek, zijn door mij hoog gewaardeerd.

De serumbepalingen werden verricht door de afdeling klinische chemie van het Sint Annadal Ziekenhuis (Dr. C. Mink, C.P. Degenaar en J. Habets) en de research laboratoria van Duphar (Dr. L.C. Post). Met opvallend geduld werden telkenmale de voor mij ogenschijnlijk moeilijke probleemstellingen door $U$ tot simpele proporties teruggebracht. Ir. A. Volovics (Dienst Informatie verwerking RUL) begeleidde de statistische aspecten van dit proefschrift; bij de uitwoering van de programma's werd dankbaar gebruik gemaakt van de diensten van Wil van Braam, Piet Zinken en Sjef Roos.

Marjo Creuzen en de heren Schlooz, Smeets en Schmeetz hielpen in het kader van hun keuzeblok mee bij het uitvoeren van het onderzoek in hoofdstuk IV en het verzamelen van literatuur gegevens.

Yenny Kurniawan maakte de illustraties, behorende bij hoofdstuk II $t / m$ VI: I Hof, overtuigd van de geneeskrachtige werking van alcohol, was zo bereildwillig do vraagstelling van deze thesis in twee tekeningen wit te beelden.

Mijn buurman J.A. Corver corrigeerde toegewijo en tot diep in de macht de vele concepten en de definitieve uitdraai op "Modern Idiom and Gramman" en Monique Brands stoeide opvallend opgewekt en talentwol met de tekstverwerker.

De firma Schrijen-Lippertz verdient alle lof woor de vlotte wijze waarop de druk van dit proefschrift plaats vond. 
Dit onderzock was in deze worm niet mogelijk geweest zonder de medewerking van het personecl op de verloskamer en alle collegae die destijds bereid waren de begeleiding van patienten met tocolytische therapie volgens het onderzoeksprotocol uit te voeren; dat uit beide geledingen ến gynaecoloog en ến (destijds) assistent zich bereid hebben verklaard om als paranymph te fungeren, weerspiegelt de prima sfeer in onze kliniek.

Graag had ik deze laatste regels volgeschreven over mijn kinderen en Konijn, hun moeder. Terwijl ze Onno. Tessa an Maartje groter bracht, typte ze de eerste 4 versies van dit proefschrift matar van haar mag ik $U$ daar niel over vertellen.

Ik ben $U$ allen zeer erkentelijk

Dieke Smit, Maastricht augustus 1983 


\section{Curriculum vitae}

$23-05-1948$

1966

1974

1974

1975-1977

1977

1977

1978

1982

1982
Geboren te Ambon, Indonesie

Eindexamen HBS-baan het Erasnus Lyceum te Almelo

Artsexamen aan de Rijksuniversiteit te Leiden

Waarmeming huisartsenpraktijk te Lemmer

Algemeen arts te Rabaul, Papua New Guinea

Vacentie-assistent afdeling Inwendige Geneeskunde in het ziekenhuis de Lichtenberg te Amersfoort

Aanvang opleiding obstetrie en gynaecologie (B-opleiding) in het Ziekenhuis St. Annadal te Maastricht

(opleider Dr. J.L.H.M. Specken)

Voortzetting opleiding obstetrie en gynaecologie (A-opleiding) in het Ziekenhuis St. Annadal te Mastricht

(opleider Prof. Dr. J. de Haan)

Inschrijving specialistenregister

Als gynaecoloog verbonden aan het Ziekenhuis St. Annadal te Maastricht

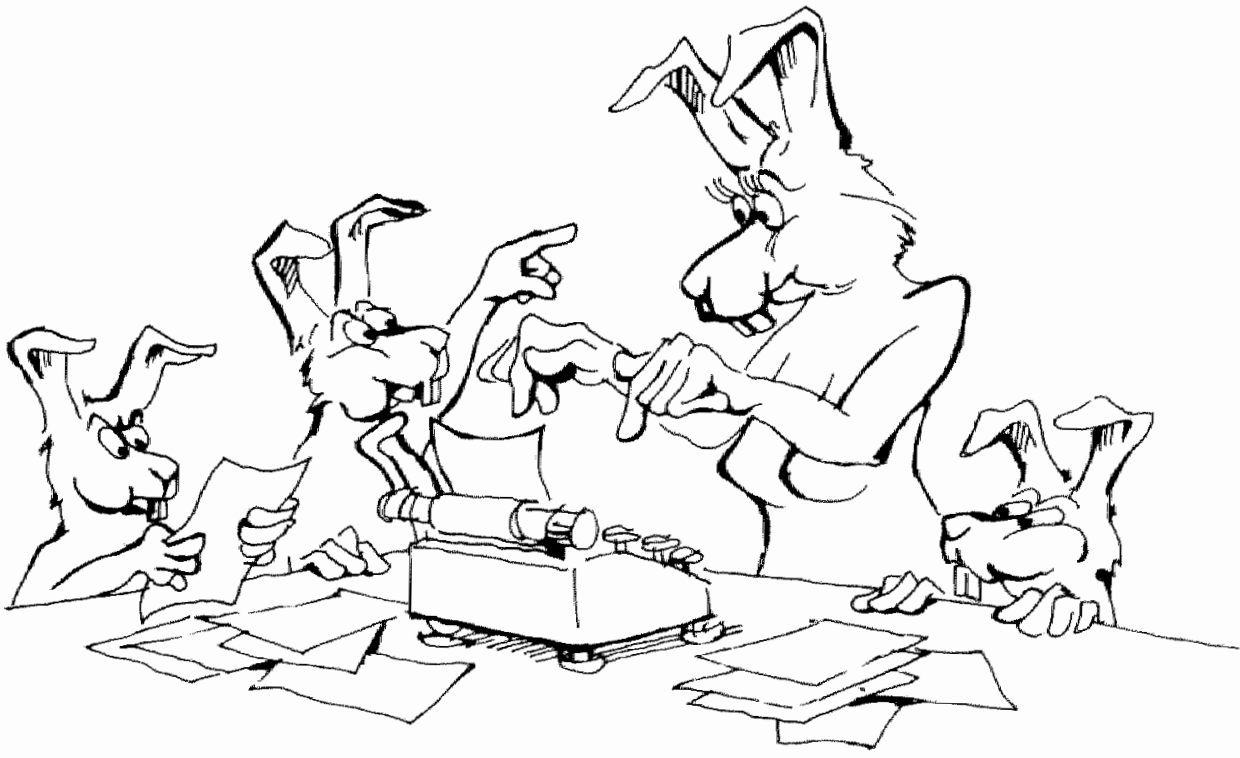

